\title{
PEATBOG: a biogeochemical model for analyzing coupled carbon and nitrogen dynamics in northern peatlands
}

\author{
Y. Wu and C. Blodau \\ Hydrology Group, Institute of Landscape Ecology, FB 14 Geosciences, University of Münster, Germany, Heisenbergstrasse 2, \\ 48149 Münster, Germany
}

Correspondence to: C. Blodau (christian.blodau@uni-muenster.de)

Received: 14 November 2012 - Published in Geosci. Model Dev. Discuss.: 4 March 2013

Revised: 26 May 2013 - Accepted: 26 June 2013 - Published: 9 August 2013

\begin{abstract}
Elevated nitrogen deposition and climate change alter the vegetation communities and carbon $(\mathrm{C})$ and nitrogen $(\mathrm{N})$ cycling in peatlands. To address this issue we developed a new process-oriented biogeochemical model (PEATBOG) for analyzing coupled carbon and nitrogen dynamics in northern peatlands. The model consists of four submodels, which simulate: (1) daily water table depth and depth profiles of soil moisture, temperature and oxygen levels; (2) competition among three plants functional types (PFTs), production and litter production of plants; (3) decomposition of peat; and (4) production, consumption, diffusion and export of dissolved $\mathrm{C}$ and $\mathrm{N}$ species in soil water. The model is novel in the integration of the $\mathrm{C}$ and $\mathrm{N}$ cycles, the explicit spatial resolution belowground, the consistent conceptualization of movement of water and solutes, the incorporation of stoichiometric controls on elemental fluxes and a consistent conceptualization of $\mathrm{C}$ and $\mathrm{N}$ reactivity in vegetation and soil organic matter. The model was evaluated for the Mer Bleue Bog, near Ottawa, Ontario, with regards to simulation of soil moisture and temperature and the most important processes in the $\mathrm{C}$ and $\mathrm{N}$ cycles. Model sensitivity was tested for nitrogen input, precipitation, and temperature, and the choices of the most uncertain parameters were justified. A simulation of nitrogen deposition over $40 \mathrm{yr}$ demonstrates the advantages of the PEATBOG model in tracking biogeochemical effects and vegetation change in the ecosystem.
\end{abstract}

\section{Introduction}

Peatlands represent the largest terrestrial soil $\mathrm{C}$ pool and a significant $\mathrm{N}$ pool. Globally, peat stores $547 \mathrm{PgC}$ (Yu et al., 2010) and 8 to $15 \mathrm{PgN}$, accounting for one-third of the terrestrial $\mathrm{C}$ and $9 \%$ to $16 \%$ of the soil organic $\mathrm{N}$ storage (Wieder and Vitt, 2006). Northern peatlands have accumulated 16 to $23 \mathrm{gC} \mathrm{m}^{-2} \mathrm{yr}^{-1}$ throughout the Holocene and $0.42 \mathrm{gN} \mathrm{m}^{-2} \mathrm{yr}^{-1}$ in the past $1000 \mathrm{yr}$ on average (Vitt et al., 2000; Turunen et al., 2002; Limpens et al., 2006; van Bellen et al., 2011a, b). Carbon accumulation in peats has been primarily attributed to low decomposition rates, which compensate for the low production in comparison to other ecosystems (Coulson and Butterfield, 1978; Clymo, 1984). The two characteristic environmental conditions in northern peatlands' high water table (WT) and low temperature, play an essential role in preserving the large $\mathrm{C}$ pool by impeding material translocation and transformation in the permanently saturated zone (Clymo, 1984) Although the total N storage in peat is substantial, the scarcity of biologically available $\mathrm{N}$ induces a conservative manner of $\mathrm{N}$ cycling in peatlands (Rosswall and Granhall, 1980; Urban et al., 1988). Sphagnum mosses are highly adapted to the nutrient-poor environment and successfully compete with vascular plants through a series of competition strategies, such as inception of $\mathrm{N}$ that is deposited from the atmosphere, internal recycling of $\mathrm{N}$, and a minimized $\mathrm{N}$ release from litter with low decomposability (Damman, 1988; Aldous, 2002).

Climate change and elevated $\mathrm{N}$ deposition are likely to alter the structure and functioning of peatlands through interactive ways that are incompletely understood. In general, drought and a warmer environment were found to affect 
vegetation composition by suppressing Sphagnum mosses and promoting vascular plants (Weltzin et al., 2003), which in turn alters litter quality, $\mathrm{C}$ and $\mathrm{N}$ mineralization rates (Keller et al., 2004; Bayley et al., 2005; Breeuwer et al., 2008), and the $C$ and $N$ balance (Moore et al., 1998; Malmer et al., 2005). In northern peatlands, nitrogen is often a limiting nutrient and regulates the rates of $\mathrm{C}$ and $\mathrm{N}$ cycling and individual processes, and thus also controls elemental effluxes to the atmosphere and discharging streams. Excessive $\mathrm{N}$ entering peatlands could induce changes in various processes that may lead to non-linear and even contrasting consequences with respect to $\mathrm{C}$ and $\mathrm{N}$ budgets, especially on longer timescales. For example, experimentally added $\mathrm{N}$ was found to increase photosynthetic capacity and growth of several Sphagnum species up to ca. $1.5 \mathrm{gN} \mathrm{m}^{-2} \mathrm{yr}^{-1}$ before causing their decline at low $\mathrm{N}$ background sites (Williams and Silcock, 1997; Granath et al., 2009). However, at high N background sites such effects occurred up to $4 \mathrm{gN} \mathrm{m}^{-2} \mathrm{yr}^{-1}$ (Limpens and Berendse, 2003), which raises the question of how peatland ecosystems adjust their structure and functioning to long-term $\mathrm{N}$ deposition. Survey studies across $\mathrm{N}$ deposition gradients ranging from 0.2 to $2 \mathrm{gN} \mathrm{m}^{-2} \mathrm{yr}^{-1}$ demonstrated a relation between $\mathrm{N}$ deposition and litter decomposition rates (Bragazza et al., 2006), in addition the effects seemed to depend on litter quality (Bragazza et al., 2009; Currey et al., 2010) and deposited $\mathrm{N}$ forms (Currey et al., 2010). In both long-term $\mathrm{N}$ fertilization experiments and survey studies, an increase in $\mathrm{N}$ content in the surface peat and in the soil water was observed at the high $\mathrm{N}$ sites (Xing et al., 2010) but enhanced $\mathrm{N}$ effluxes in the form of $\mathrm{N}_{2} \mathrm{O}$ remained elusive (Bubier et al., 2007). In contrast, $\mathrm{N}_{2} \mathrm{O}$ emission was found in short-term $\mathrm{N}$ and $\mathrm{P}$ fertilization experiments (Lund et al., 2009). Laboratory and field experiments aiming to quantify the combined effects of temperature, WT and N elevation have thus often arrived at contradictory conclusions, due to the interplay of effects in time and space (Norby et al., 2001; Breeuwer et al., 2008; Robroek et al., 2009). Furthermore, elevated $\mathrm{N}$ deposition was recently suggested to affect soil temperature and moisture through changes in the vegetation community with potential feedbacks on elemental cycles (Wendel et al., 2011).

Ecosystem modeling has become an important approach in analyzing the interacting effects of climate and $\mathrm{N}$ deposition on peatlands and in making long-term predictions; examples are provided by PCARS (Frolking et al., 2002), ecosys (Dimitrov et al., 2011), Wetland-DNDC (Zhang, 2002), and MWM (St-Hilaire et al., 2010). While models have been thoroughly developed to investigate peatland $\mathrm{C}$ cycling (e.g. PCARS, MWM), there have been few attempts to integrate $\mathrm{N}$ cycling into peatland models, although $\mathrm{N}$ is mostly considered to be the limiting factor on primary production (Heijmans et al., 2008). In the mentioned models, $\mathrm{N}$ is generally passively bound to $\mathrm{C}$ pools by $\mathrm{C} / \mathrm{N}$ ratios, while active nitrogen transformation and translocation among $\mathrm{N}$ pools is omitted.
To make progress towards closing this gap, we present a novel model for the analysis of the coupled $\mathrm{C}$ and $\mathrm{N}$ cycles in northern peatlands. The model is designed to fulfill the following objectives: (1) to clarify the interaction between $\mathrm{C}$ and $\mathrm{N}$ cycling in vegetation, soil organic matter and soil water; (2) to determine key processes that control the $\mathrm{C}$ and $\mathrm{N}$ balance of northern peatlands in the short and long-term; (3) to quantify $\mathrm{C}$ and $\mathrm{N}$ pools and cycling rates in peatlands; (4) to characterize their sensitivity to $\mathrm{N}$ availability and climate change; and (5) to predict the combined impact of elevated $\mathrm{N}$ deposition and climate change on peatland $\mathrm{C}$ and $\mathrm{N}$ cycling.

In this paper, we focus on the integration of $\mathrm{C}$ and $\mathrm{N}$ cycling through vegetation, soil organic matter and soil water, the coupling of $\mathrm{C}$ and $\mathrm{N}$ throughout the ecosystem, and the consistency of mass movements between pools. We first highlight the structural design and principles that governed the modeling process, and then explain the components of the model by focusing on the individual submodels. To improve readability of the text the equations are listed in the appendix. We subsequently present an evaluation of the simulated WT dynamics, $\mathrm{C}$ fluxes, depth profiles of $\mathrm{CO}_{2}$ and $\mathrm{CH}_{4}$ in soil water, and $\mathrm{C}$ and $\mathrm{N}$ budgets. The model output is compared against observations for the well-characterized Mer Bleue Bog (MB), Ontario, Canada. We also present sensitivity analyses for environmental controls, such as temperature, precipitation, and $\mathrm{N}$ deposition, and for some calibrated key parameters. Finally we demonstrate the potential of the model for analyzing the effects of experimental long-term $\mathrm{N}$ deposition and climate change.

\section{Model description}

The PEATBOG (Pollution, Precipitation and Temperature impacts on peatland Biodiversity and Biogeochemistry; see acknowledgements) model version 1.0 was implemented in Stella®and integrates four submodels: environment, vegetation, soil organic matter (SOM), dissolved C and N (Fig. 1). The environment submodel generates daily WT depth from a modified mixed mire water and heat (MMWH) model (Granberg et al., 1999) and depth profiles of soil moisture, peat temperature and oxygen concentration. The vegetation submodel simulates the $\mathrm{C}$ and $\mathrm{N}$ flows and the competition for light and nutrients among three plant functional types (PFTs): mosses, graminoids and shrubs. Most of the algorithms of plant physiology were adopted from the Hurley pasture (HPM) model (Thornley and Verberne, 1989; Thornley et al., 1995; Thornley, 1998a). Modifications were made for mosses and for the competition among PFTs in the nutrient-poor environment. Litter and exudates from the vegetation submodel flow into the SOM submodel and are decomposed into dissolved $\mathrm{C}$ and $\mathrm{N}$. The dissolved $\mathrm{C}$ and $\mathrm{N}$ submodel tracks the fate of dissolved $\mathrm{C}$ and $\mathrm{N}$ as DOC, $\mathrm{CH}_{4}, \mathrm{CO}_{2}$ and DON, $\mathrm{NH}_{4}^{+}$, and $\mathrm{NO}_{3}^{-}$. The model does not 
consider hummock-hollow microtopography of peatlands, which in other studies had no statistically significant effect when simulating ecosystem level $\mathrm{CO}_{2}$ exchange (Wu et al., 2011).

\subsection{Model structure and principles}

The following three principles were imbedded in the model in terms of scale, resolution and structure:

\subsubsection{High spatial and moderate temporal resolution}

In comparison to other biogeochemical process models of peatland C cycling (Frolking et al., 2002; St-Hilaire et al., 2010) that primarily focus on the ecosystem-atmosphere interactions, we increased the vertical spatial representation and kept the temporal resolution fairly low. We divided the belowground peat into 20 layers $(i)$ with a vertical resolution of $5 \mathrm{~cm}$ except for an unconfined bottom layer. This structure applies to all belowground pools and processes. The rationale for the comparatively fine spatial resolution lies in the critical role of soil hydrology for the $\mathrm{C}$ and $\mathrm{N}$ cycles and the necessity to represent physical and microbial processes (Trumbore and Harden, 1997). Spatial distributions of water and dissolved chemical species are generated and mass movement and balances are examined throughout layers and pools, which allows for tracing the fate of $\mathrm{C}$ and $\mathrm{N}$ belowground. The high resolution allows to explicitly include the activity of plant roots and their local impact on $\mathrm{C}$ and $\mathrm{N}$ pools. Plant roots showed morphological changes upon WT fluctuation and nutrient input in bogs (Murphy et al., 2009; Murphy and Moore, 2010). Root litter also provides highly decomposable organic matter to deeper peat and serves as a substrate for microbial respiration. Moreover, roots can act as sensitive conductors of $\mathrm{N}$ deposition to deep peat via root chemistry and litter quality (Bubier et al., 2011; Bragazza et al., 2012). The layered structure assists in mapping the belowground micro-environment for simulating the sensitive interactions of soil moisture, roots and microbial activity. The model computes and simulates processes on a daily time step, as does for example the HPM model (Thornley et al., 1995) and the wetland-DNDC model (Zhang, 2002). The moderate temporal resolution is adequate for the model soil $\mathrm{C}$ in the short- and long term (Trettin et al., 2001).

\subsubsection{Stoichiometry controls $\mathrm{C}$ and $\mathrm{N}$ cycles}

We did not stipulate critical mass fluxes as constraints on $\mathrm{C}$ and $\mathrm{N}$ cycling. Instead these constraints are generated in the model from changes in biological stoichiometry. This structure has the advantage that the interactions between $\mathrm{C}$ and $\mathrm{N}$ fluxes and temporal and spatial changes in pools sizes control the mobility of the elements. As in some terrestrial $\mathrm{C}$ and $\mathrm{N}$ models (Zhang et al., 2005), $\mathrm{N}$ flows are driven by $\mathrm{C} / \mathrm{N}$ ratio gradients from low $\mathrm{C} / \mathrm{N}$ ratio to high $\mathrm{C} / \mathrm{N}$ ratio compartments. The $\mathrm{C} / \mathrm{N}$ ratios of all pools are in turn modified by their associated flows, reflecting the organisms' requirement to maintain their chemical composition in certain ranges. Results from field manipulation experiments suggested thresholds of the N deposition level, above which the Sphagnum moss filter fails and mineral $\mathrm{N}$ enters soil water (Lamers et al., 2001; Bragazza et al., 2004). Flux-based critical loads of $\mathrm{N}$ for Sphagnum moss were suggested as the high end of the Sphagnum tolerance range, where the values are between $0.6 \mathrm{gN} \mathrm{m}^{-2} \mathrm{yr}^{-1}$ (Nordin et al., 2005) and $1.5 \mathrm{gN} \mathrm{m}^{-2} \mathrm{yr}^{-1}$ (Vitt et al., 2003). Threshold values in stoichiometry terms appear to be less variable, ranging from $15 \mathrm{mgN} \mathrm{g}^{-1}$ (Van Der Heijden et al., 2001; Xing et al., 2010) to $20 \mathrm{mgN} \mathrm{g}^{-1}$ dry mass (Berendse et al., 2001; Granath et al., 2009). The critical load of ca. $1 \mathrm{gN} \mathrm{m}^{-2} \mathrm{yr}^{-1}$ was linked to a stoichiometry thresholds of 30 (N/P ratio) and 3 (N/K ratio) in Sphagnum mosses (Bragazza et al., 2004). The model internally generates $\mathrm{C} / \mathrm{N}$ ratios, or $\mathrm{C} / \mathrm{N} / \mathrm{P}$ ratios, for all compartments to control the $\mathrm{N}$ flows in plants and microorganisms.

\subsubsection{Consistent conceptualization of carbon and nitrogen reactivity}

Differences in the mobility of $\mathrm{C}$ and $\mathrm{N}$ compartments were implemented using a two-pool concept throughout the model. Similar to decomposition models that distinguish the quality of soil organic matter (Grant et al., 1993; Parton et al., 1993), $\mathrm{C}$ and $\mathrm{N}$ are presented in labile $(L)$ and recalcitrant $(R)$ pools in SOM. In addition, the model differentiated $\mathrm{C}$ and $\mathrm{N}$ pools based on quality in vegetation, into structural (struc) pools (Fig. 2). The pasture vegetation model HPM (Thornley et al., 1995; Thornley, 1998b) was adopted, where $\mathrm{C}$ and $\mathrm{N}$ in grass and legumes were separated in structural and substrate pools in shoots (sh) and roots (rt) for 4 age categories. Considering our focus on competition between plant functional types, vegetation was not conceptualized in terms of age categories but instead classified into 3 plant functional types (PFTs) $(j: 1=$ mosses, $2=$ graminoids and $3=$ shrubs) that are characterized by distinctive ecological functions (Fig. 3) in our model. The plant functional types differ in the decomposability of the litter, which was represented by the different mass fractions of the labile carbon pool in the litter. The fraction of labile litter was assumed to be $0.1,0.3$ and 0.2 in mosses, graminoids and shrubs, respectively (Inglett et al., 2012). Once the litter is deposited the litter merges into one labile and one recalcitrant soil organic matter pool. The remaining fraction of the plant litter is assigned to be recalcitrant and represents the input into the recalcitrant soil organic matter pools. Thus, the composition of plants, as a result of net primary production and litter fall, is adjusted to physical conditions and $\mathrm{N}$ input and alters SOM quality via changes in litter quality $(Q)$. 


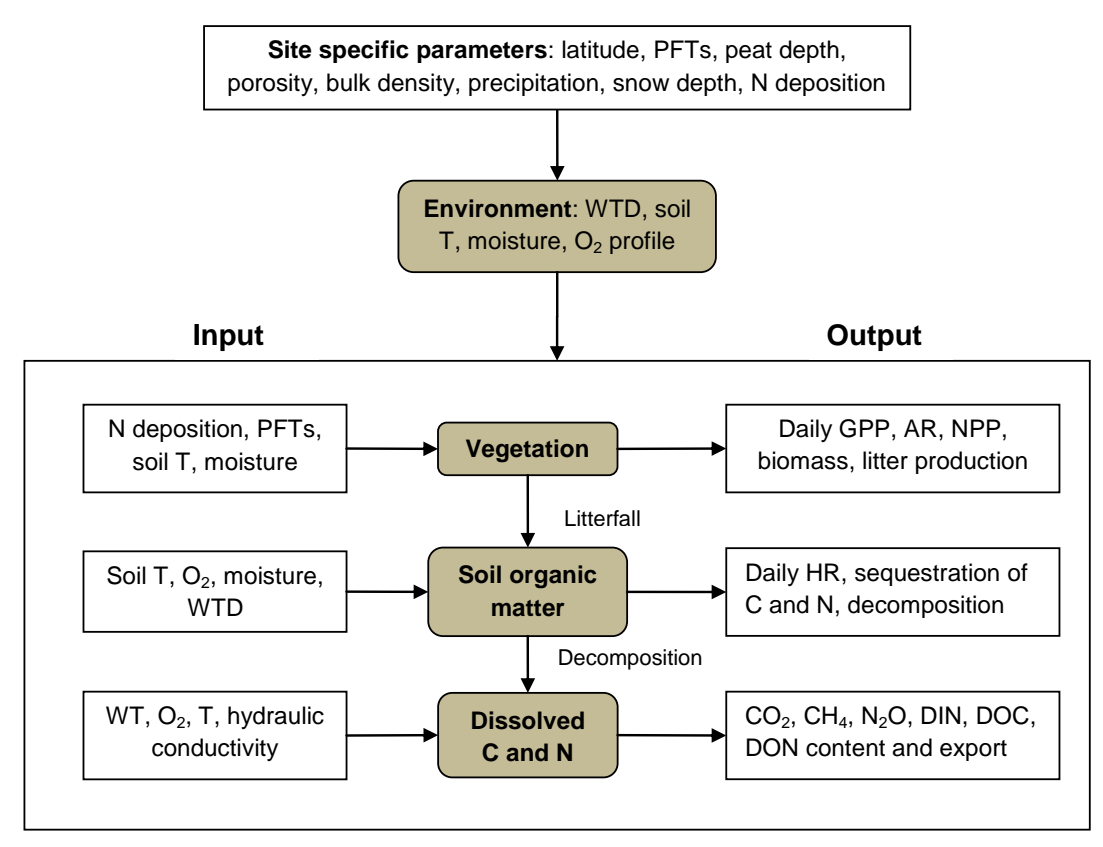

Fig. 1. Model structure.

\subsection{Structural adaptations for modeling peatland biogeochemistry}

Modifications were made to the adopted algorithms of the MMWH and HPM models for compatibility with our modeling purpose and model structure. The main modifications and novel features of the PEATBOG model are:

\subsubsection{Competition among Plant Functional Types (PFTs)}

Plant functional types compete for light and nutrients through their morphology and nutrient utilization. We modified the algorithms of competition among plant functional types for these controls to better represent the shading effects among PFTs and the nutrient-poor environment. Competition among plants was modeled using PFTs previously, where the depth and biomass of roots mainly determined superiority in competition (Van Oene et al., 1999; Pastor et al., 2002; Heijmans et al., 2008). We focused instead on the effect of light for PFT competition that is controlled by shading effects through canopy layers (Fig. 3). This differs from the utilization of the leaf area index, which determines the share of total photosynthesis in the HPM model (Thornley et al., 1995). In the PEATBOG model, the uptake of $\mathrm{N}$ is also modified to be specific for each soil layer and PFT. It includes the uptake of three forms of $\mathrm{N}$ in the PFTs so that $\mathrm{N}$ availability varies for roots of each PFT in the same location. In addition to inorganic $\mathrm{N}$ sources $\left(\mathrm{NH}_{4}^{+}\right.$and $\left.\mathrm{NO}_{3}^{-}\right)$, as modeled in some $\mathrm{C}$ and $\mathrm{N}$ cycling models (Aber et al., 1997; Van der Peijl and Verhoeven, 1999), DON is included as a third N source, acknowledging its abundance (Moore et al., 2005) and potential importance in nutrient-poor environments, such as bogs (Jones et al., 2005; Nasholm et al., 2009) (Fig. 3).

\subsubsection{Decoupling of $\mathrm{O}_{2}$ boundary and WT boundary}

The interface between oxic and anoxic conditions and unsaturated and saturated peat (i.e. the water table position, WT) are separately modeled and control biogeochemical and physical processes, respectively. Recent findings questioned that the long-term WT is the sole control on biogeochemical processes in peat as well as the acrotelm and catotelm concept in modeling of peatlands (Morris et al., 2011). Meanwhile $\mathrm{O}_{2}$ was found well above and below the WT in peats, for instance during drying and rewetting experiments in a degraded fen site with dense soil (Estop-Aragonés et al., 2012). The decoupling of redox conditions from the WT spatially and temporally in dense soils is potentially important for the partitioning of respired $\mathrm{C}$ into $\mathrm{CO}_{2}$ and $\mathrm{CH}_{4}$ during the decomposition of peat. We calculated $\mathrm{O}_{2}$ concentration in each layer to regulate energy-limited processes such as $\mathrm{CH}_{4}$ oxidation and peat decomposition. Water table, on the other hand, serves as a control on moisture-limited biological or physical processes, such as root metabolism and diffusion. The belowground controls on $\mathrm{CH}_{4}$ production and emissions and the advantages and disadvantages of our representation of oxygen and soil moisture dynamics will be further discussed in a future manuscript. 


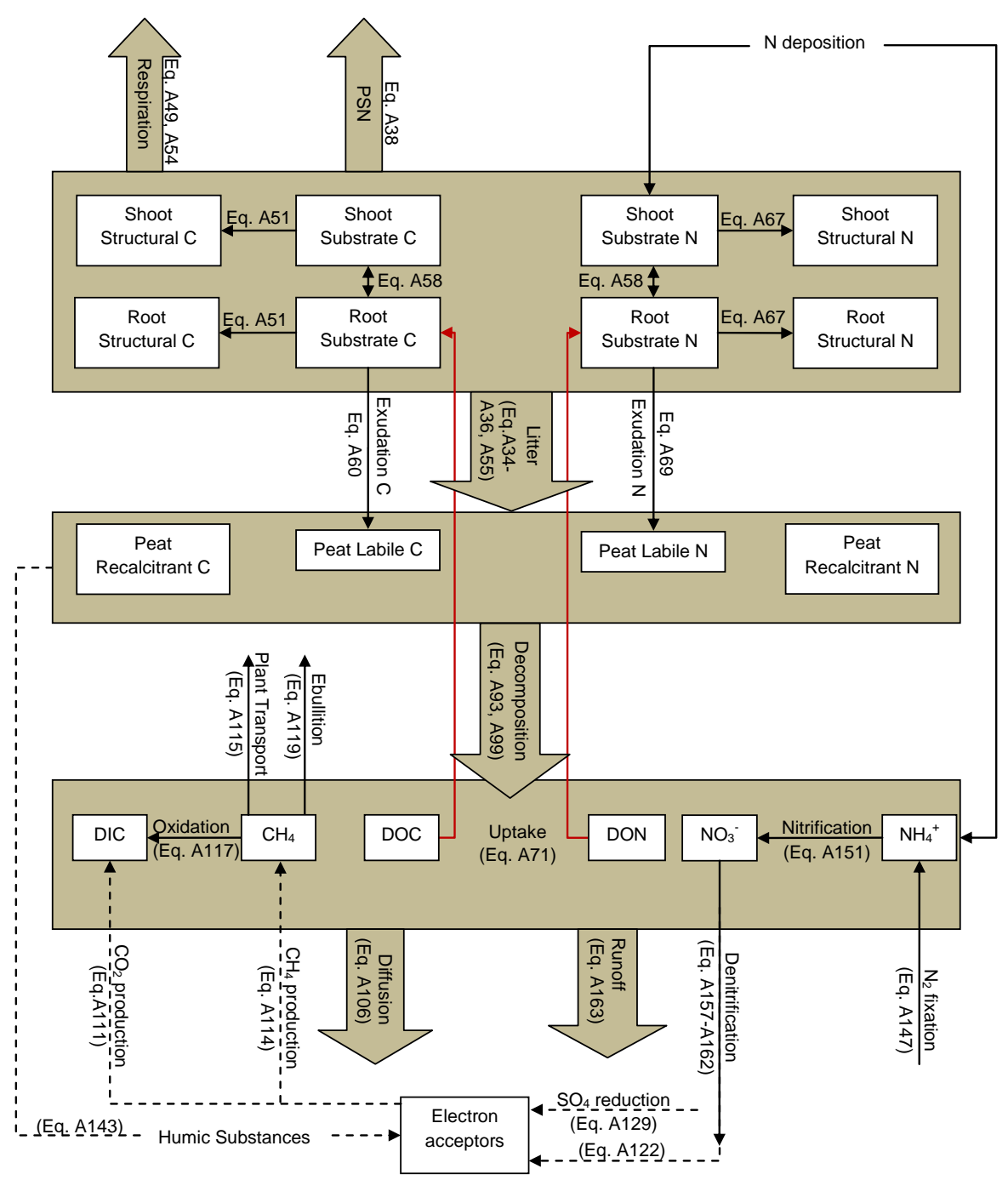

Fig. 2. Schematic $\mathrm{C} \mathrm{N}$ pools and flows. The black lines are material flows and the dotted lines are information flows. Equations are equations as listed in Appendix A.

\subsection{Submodel 1 - environmental controls}

Physical boundary conditions, such as day length, degree days, water table depth, soil moisture, temperature and depth profiles of $\mathrm{O}_{2}$, are generated by the model to control physiochemical and biological processes.

Day length (DL), which in the model controls photosynthesis, varies for geographic position of the site and day of year. The daily day length value is obtained from the angle between the setting sun and the south point, which in turn is calculated from the declination of the earth and the geographical position of the site (Brock, 1981) (Appendix A, Eqs. A14 and A15). Declination of the earth is the angular distance at solar noon between the sun and the equator and positive for the Northern Hemisphere. The value of declination is approximately calculated by Cooper (1969) using the day of the year.
Temperature is modeled by sinusoidal equations (Carslaw and Jaeger, 1959) and modified by converting a dampening depth into thermal conductivity (Appendix A, Eq. A13). Thermal conductivity ( $\left.K_{\text {thermal }}\right)$ is adjusted for each layer for peat compaction and snow coverage that delays the thermal exchange in winter and early spring (Fig. S1a, Supplement).

Degree days (DD) represent the accumulation of cold days and trigger defoliation (Frolking et al., 2002; Zhang, 2002). Similar to other models, defoliation occurs on the day when DD reaches minus 25 degrees, with accumulated temperature of lower than 0 degrees after day 181 of the year (1 July in non-leap years).

Water table (WT) depth is simulated by calculating the water table depth from the water storage of peat using a modified version of the Mixed Water and Heat model (MMWH) (Granberg et al., 1999). Precipitation and snowmelt represent water inputs, and are obtained from local meteorological 


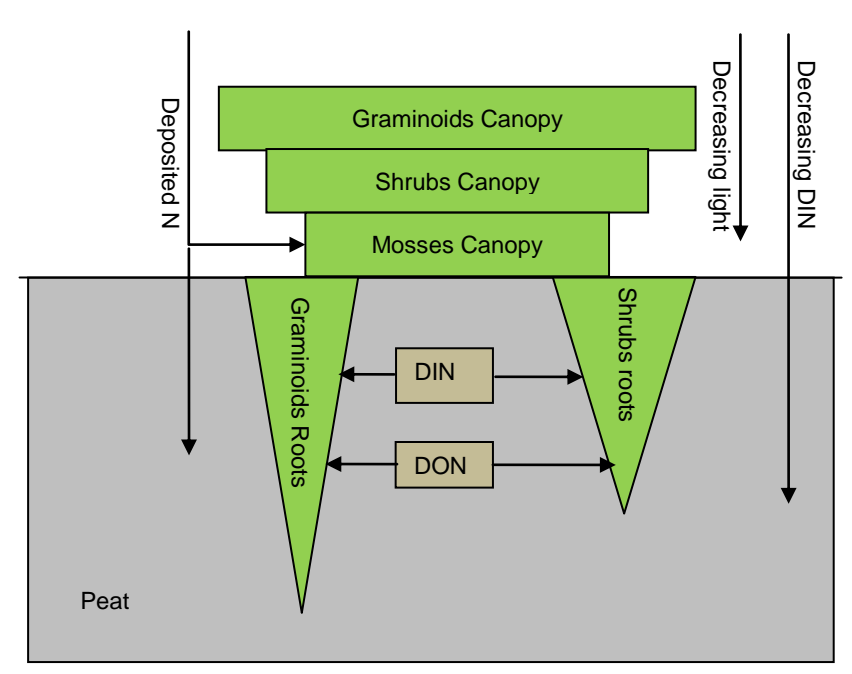

Fig. 3. Plant competition for nutrient and light.

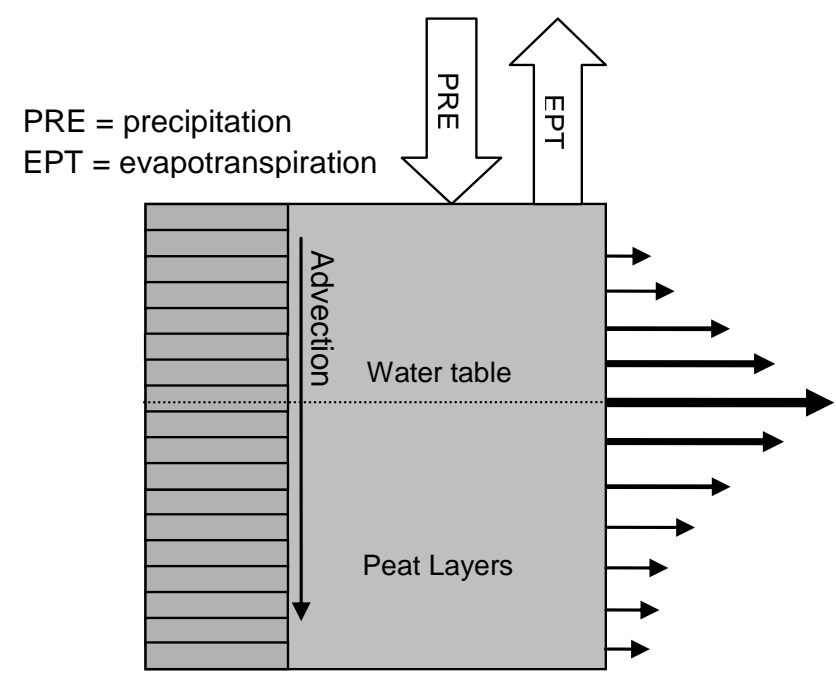

Runoff from each layer varies according to hydraulic conductivity

Fig. 4. Schematic soil water flow.

conductivity is lower when pores are unsaturated (Hemond and Fechner-Levy, 2000) (Fig. S1d).

The depth profiles of $\mathrm{O}_{2}$ concentrations are simulated to locate the oxic-anoxic interface. Oxygen diffuses from the surface to deeper soil layers and is consumed directly or indirectly by the oxidization of peat $\mathrm{C}$ to $\mathrm{CO}_{2}$ (Appendix A, Eq. A12). For the simulation of oxygen-dependent biogeochemical processes we chose a dichotomous distribution of $\mathrm{O}_{2}$, where the boundary of oxic/anoxic conditions is set at $5 \mu \mathrm{mol} \mathrm{L}^{-1}$ (Liou et al., 2008).

\subsection{Submodel 2 - vegetation}

Carbon in vascular plants is represented by four pools: shoot substrate C (sh_subsC), root substrate C (rt_subsC), shoot structural C (sh_strucC), and root substrate $\mathrm{C}$ (rt_subsC) (Fig. 2). Substrate $\mathrm{C}$ and structural $\mathrm{C}$ refer to metabolic activated $\mathrm{C}$ and recalcitrant $\mathrm{C}$, respectively. Substrate pools conduct metabolic activities (i.e. photosynthesis, respiration) and structural pools perform phenological activities (i.e. growth, litter production). The flow from substrate $\mathrm{C}$ to structural C leads to plant growth (Appendix A, Eq. A33). Each $\mathrm{C}$ pool or flow is bound to an $\mathrm{N}$ pool or flow by the $\mathrm{C} / \mathrm{N}$ ratio of the specific pool. Furthermore, shoots are divided into stems and leaves and roots into coarse and fine roots by ratios specific to the PFT. Mosses are represented by 4 aboveground pools and two compartments: capitulum and stem. The $\mathrm{C}$ and $\mathrm{N}$ contained in exudates are transferred from the vegetation into the uppermost labile $\mathrm{C}$ and $\mathrm{N}$ pools in the soil. Unlike $\mathrm{N}$ uptake by vascular plants from soil water, $\mathrm{N}$ uptake by mosses is restricted to atmospheric supply.

Most $\mathrm{C}$ and $\mathrm{N}$ material flows are driven by $\mathrm{C}$ concentration gradients except for a few processes controlled by $\mathrm{N}$ 
(i.e. $\mathrm{N}$ uptake, $\mathrm{N}$ recycling from litter production). The phenology and competing strategies of PFTs are modeled as follows: (1) considering the seasonal $\mathrm{C}$ and $\mathrm{N}$ loss in leaves of deciduous shrubs; (2) PFT-specific N flows during growth, recycling and litter production; (3) competition among PFT is implemented through shading effects, tolerance to moisture and temperature, distribution of $\mathrm{C}$ and $\mathrm{N}$ among shoots and roots, as well as turnover rates. In general, the photosynthetic nutrient-use efficiency (the ratio of photosynthesis rate and nitrogen content per leaf area) is higher in herbaceous than in evergreen woody species (Hikosaka, 2004). The growth rates in deciduous species (graminoids and deciduous shrubs) are higher than in evergreen shrubs, which in turn is higher than in mosses (Chapin III and Shaver, 1989). Graminoids are more competitive in the deep soil attributed to the longer roots (Murphy et al., 2009). Mosses have the advantage of aboveground $\mathrm{N}$ uptake and filtration. Below we discuss the modeling of these competition strategies.

\subsubsection{Photosynthesis (PSN) and competition for light}

Competition for PAR is implemented through shading effects. The light level that reaches a specific PFT after interception by a taller PFT determines the $\mathrm{C}$ assimilation of this PFT (Fig. 3). For each PFT, canopy PSN is integrated from daily leaf PSN by a light attenuation coefficient $\left(k_{\text {ext }}\right)$, leaf area index (LAI) and day length (DL) (Appendix A, Eq. A38). The coefficient $k_{\text {ext }}$ is unitless, the values are 0.5 for graminoids (Heijmans et al., 2008), 0.97 for shrubs (Aubin et al., 2000), and assumed to be 0.9 for mosses. LAI is determined by leaf structural $\mathrm{C}$ mass and specific leaf area (SLA) of the PFT. The PSN rate for the top canopy layer of each PFT (LeafPSN ${ }_{j}$ ) is calculated by a non-rectangular hyperbola (Fig. S2f, Appendix A, Eq. A40). The two parameters $\alpha_{j}$ and $\xi$ control the shape of the hyperbola curves. Parameter $\alpha_{j}$ represents the photosynthetic efficiency, which is controlled by WT depth, the air temperature $\left(T_{\text {air }}\right)$ and atmospheric $\mathrm{CO}_{2}$ level $\left(\mathrm{CO}_{2}\right.$,air $)$ (Appendix A, Eq. A42). The spring PSN of mosses starts when the snow depth falls below $0.2 \mathrm{~cm}$. The variable $\mathrm{LI}_{j}$ is the PAR incepted by the canopy of $\mathrm{PFT}_{j}$ (umol m $\mathrm{u}^{-2} \mathrm{~s}^{-1}$ ). The assumptions here were that radiation diminishes along with canopy depth and each canopy depth contains one PFT solely.

The asymptote of leaf photosynthesis rate $\left(P_{\max }\right.$ in $\mathrm{gCO}_{2} \mathrm{~m}^{-2} \mathrm{~s}^{-1}$ ) is regulated by $T_{\text {air }}, \mathrm{CO}_{2 \text {,air, WT depth, } \mathrm{N}}$ content in plant shoots and the season. The maximum PSN rate $\left(P_{\max , 20}, \mathrm{~g} \mathrm{CO}_{2} \mathrm{~m}^{-2} \mathrm{~s}^{-1}\right)$ occurs in an optimal environment, is also referred to as PSN capacity, and is often derived from measurements. The values of $P_{\max , 20}$ vary among and within growth forms and follow the general sequence of deciduous $>$ evergreens $>$ mosses (Chapin III and Shaver, 1989; Ellsworth et al., 2004). The maximum PSN rate $P_{\max , 20}$ is $0.002 \mathrm{~g} \mathrm{CO}_{2} \mathrm{~m}^{-2} \mathrm{~s}^{-1}$ for graminoids and mosses following HPM (Thornley, 1998a), and $0.005 \mathrm{~g} \mathrm{CO}_{2} \mathrm{~m}^{-2} \mathrm{~s}^{-1}$ for shrubs based on the ranges in Small (1972). The temperature dependence $\left(f_{T, P \max , j}\right)$ of $P_{\max }$ is conceptualized as sigmoidal curve with PFT-specific optimal, maximum and minimum temperature for photosynthesis and curvature $q$ (Fig. S2e, Appendix A, Eq. A43). The WT depth dependency of $P_{\max }\left(f_{\mathrm{m}, P \max , j}\right)$ for mosses follows Frolking et al. (2002) and is an exponential function with PFT-specific base $\left(a_{w, j}\right)$ for vascular plants (Fig. S2a and b). The model considers season and nutrient availability effects on $P_{\max }$. Seasonal change $\left(f_{\text {season, } P \max }\right)$ affects mosses alone between 0 to 1 and was derived from the maximum rates of carboxylation $\left(V_{\max }\right)$ in spring summer and autumn (Williams and Flanagan, 1998) (Fig. S2c).

Potential N stress on photosynthesis is modeled by using PFT-specific photosynthetic $\mathrm{N}$ use efficiencies. Although there are interacting controls on the $\mathrm{N}$ economy of plant photosynthesis, such as $\mathrm{N}$ effects on Rubisco activity, Rubisco regeneration and the distribution of $\mathrm{N}$ in leaves, there seems to be a generalized linear relation of foliar $\mathrm{N}$ content and PSN capacity across growth forms and seasons (Sage and Pearcy, 1987; Reich et al., 1995; Yasumura et al., 2006). The ratio of PSN capacity and foliar $\mathrm{N}$ concentration is defined as photosynthetic nitrogen use efficiency (PNUE) (Field and Mooney, 1986). In general, evergreens have lower PNUE and larger interception than the deciduous shrubs (Fig. S2d, Appendix A, Eq. A47) (Hikosaka, 2004). To reflect $\mathrm{N}$ use strategies of growth forms, we implemented PNUE values for PFTs following the sequence: graminoids $>$ shrubs $>$ mosses, and interception values reversely. In addition, a toxic effect $\left(f_{\mathrm{N} \text {,toxic }}\right)$ is applied with regard to mosses when the substrate $\mathrm{N}$ concentration exceeds the maximum $\mathrm{N}$ concentration at $20 \mathrm{mg} \mathrm{g}^{-1}$ (Granath et al., 2009).

\subsubsection{Competition for nutrients}

PFTs compete for $\mathrm{N}$ through two processes: filtration of deposited $\mathrm{N}$ by mosses and the uptake of $\mathrm{N}$ among vascular plants roots. Nitrogen deposited from the atmosphere is first absorbed by moss and then enters soil water to become available to vascular plants. The $\mathrm{N} / \mathrm{P}$ ratio of mosses is used as a regulator of $\mathrm{N}$ pathways and an indicator of $\mathrm{N}$ saturation in mosses. A fraction of $95 \%$ of the deposited $\mathrm{N}$ is absorbed by moss until the N/P ratio reaches 15 (Aerts et al., 1992), above which $\mathrm{N}$ absorption decreases owing to the co-limitation of $\mathrm{N}$ and $\mathrm{P}$ on PSN rates. We assume mosses become $\mathrm{N}$ saturated when the N/P ratio exceeds 30 (Bragazza et al., 2004), above which the uptake fraction declines to zero. Due to the lack of $\mathrm{P}$ pools in the current model version, the initial moss $\mathrm{N} / \mathrm{P}$ ratio is assumed to be 10 in mosses (Jauhiainen et al., 1998).

The competition for uptake of $\mathrm{N}$ among PFTs is conducted through the competitive advantages in the architecture of the roots and capabilities for uptake of three $\mathrm{N}$ sources $\left(\mathrm{NH}_{4}^{-}\right.$, $\mathrm{NO}_{3}^{-}$and DON) (Fig. 3). The root distribution in soil is modeled using a asymptotic equation (Gale and Grigal, 1987; 
Jackson et al., 1996) with a PFT-specific distribution coefficient (rt_k) (Murphy et al., 2009) (Appendix A, Eq. A27). Graminoids have a larger $\mathrm{rt} \_k$ than shrubs, indicating more roots in deeper layers that allow utilization of $\mathrm{N}$ in deeper peat. The $\mathrm{N}$ uptake rate is affected by the surface area rather than the biomass of the fine roots. Specific root lengths $L_{j}$ that vary with root diameters are used to convert the dry biomass to the surface area of roots (Kirk and Kronzucker, 2005). The diameters of the fine roots were set to be between 0.005 to $0.1 \mathrm{~cm}$ for the "true fine roots" that are responsible for $\mathrm{N}$ uptake (Valenzuela-Estrada et al., 2008).

Nitrogen uptake is modeled using Michaelis-Menten equations (Appendix A, Eq. A71-A73), controlled by the soil temperature, the root biomass of the layer and the substrate $\mathrm{C}$ and $\mathrm{N}$ concentrations in plants. Parameters $V_{\max }$ and $K_{\mathrm{m}}$ for the DIN uptake were derived from the model of Kirk and Kronzucker (2005) while those for DON uptake were calibrated based on one of the few quantitative studies for an Arctic Tundra (Kielland, 1994), where $V_{\max }$ for DON uptake was 0.0288 to $0.048 \mathrm{mmol} \mathrm{g}^{-1} \mathrm{day}^{-1}$ for shrubs (Ledum) and 0.012 to $0.096 \mathrm{mmol} \mathrm{g}^{-1} \mathrm{day}^{-1}$ for graminoids (Carex/Eriophorum). The effects of substrate $\mathrm{C}$ and $\mathrm{N}$ concentration in plants on $\mathrm{N}$ uptake rates were derived from the HPM model (Thornley and Cannell, 1992). The half saturation constant of substrate $\mathrm{N}$ was adjusted to be smaller for shrubs and mosses than for graminoids. The temperature influence on $\mathrm{N}$ uptake is modeled using $Q_{10}$ functions for active $\mathrm{NO}_{3}^{-}$uptake and linear functions for passive $\mathrm{NH}_{4}^{+}$uptake (Glass et al., 2001; Williams and Miller, 2001; Miller and Cramer, 2004). Despite the abundance of DON in soil water, which is one order of magnitude larger than the concentration of DIN in the field (Kranabetter et al., 2007; Nasholm et al., 2009), the capability of DON uptake by plants is limited to low molecular weight DON (e.g. glycine, aspartate and glutamate) (Jones et al., 2005). We assumed a fraction of 0.2 of total DON concentration to be bio-available to plants, according to reports on arctic tundra and two permafrost taiga forests (Jones and Kielland, 2002; Atkin, 2006). Pools of $\mathrm{NH}_{4}^{+}, \mathrm{NO}_{3}^{-}$, and DON are simulated in the dissolved $\mathrm{C}$ and $\mathrm{N}$ submodel.

\subsection{Submodel 3 - soil organic matter dynamics}

The soil organic matter (SOM) submodel simulates peat decomposition and accumulation using a multi-layer approach. The litter produced from the vegetation submodel is added to the topsoil layer and into the rooted layers of the peat. In each layer, $\mathrm{C}$ and $\mathrm{N}$ are present in labile $(L)$ and recalcitrant $(R)$ pools. The decomposition of each SOM pool was modeled following the single pool model of Manzoni et al. (2010). Pool $L$ and $R$ are decomposed simultaneously at rates that are determined by their $\mathrm{C} / \mathrm{N}$ ratios, an environmentally controlled decomposition rate constant $k$, and the availability of mineral N. Three fates of the decomposition products are possible: (1) leaching as dissolved organic matter
(DOM), (2) re-immobilization into microbial biomass, and (3) conversion into dissolved inorganic carbon (DIC) and dissolved inorganic nitrogen (DIN). DOM was extracted from SOM pools by a constant fraction, which is empirically related to the local precipitation level of the site (Appendix A, Eqs. A90 and A96). The value used here (0.05) is slightly smaller than the lower end (0.06) of the suggested range for ecosystems in general (Manzoni et al., 2010), owing to the small hydraulic conductivity in northern peatlands. The remaining SOM is either mineralized into dissolved inorganic matter or immobilized into microbial biomass with a microbial efficiency $(e)$, indicating the immobilized fraction of the decomposed SOM (Appendix A, Eq. A84). Parameter $e$ is empirically calculated from the initial $\mathrm{C} / \mathrm{N}$ ratios of the SOM pools, which in turn is controlled by the composition of litter produced from each PFT. For simplicity, microbial biomass is considered as a constant part of SOM. The actual $\mathrm{N}$ decomposition rate, excluding for the $\mathrm{N}$ immobilization to microbial biomass, can be either positive or negative. Positive rates reveal net mineralization from SOM N pools to dissolved $\mathrm{NH}_{4}^{+}$pools and negative rates indicate net immobilization. The "critical N level" is used as an indicator of the $\mathrm{N}$ concentration at which immobilization balances mineralization (Berg and Staaf, 1981). The "critical N level" varies according to the $\mathrm{C} / \mathrm{N}$ ratio of microorganisms, the DOM leaching fraction, $e$ and another factor representing the $\mathrm{N}$ preferences of microorganisms during decomposition $\left(\alpha_{E} \mathrm{~N}_{\text {prefer }}\right)$ (Appendix A, Eq. A86). The nitrogen preference of microorganisms $\left(\alpha_{E} \mathrm{~N}_{\text {prefer }}\right)$ is a multiplier larger than 1 and is limited by the asymptotic $\mathrm{C} / \mathrm{N}$ ratio of $\mathrm{SOM}$ at decomposition equilibrium (Appendix A, Eq. A95).

In addition to the control of $\mathrm{N}$ concentration in SOM, the availability of soil mineral $\mathrm{N}$ also affects the decomposition rates. Nitrogen addition experiments showed neutral or negative effects on the decomposition rates of SOM due to contrary effects on the decomposition of labile and recalcitrant OM: a decrease in the decomposition rates of more recalcitrant $\mathrm{OM}$ and an increase in that of more labile OM (Neff et al., 2002; Janssens et al., 2010; Currey et al., 2011). We adopted the quantitative relation from the Integrated Biosphere Simulator model (IBIS) (Liu et al., 2005), by converting mineral $\mathrm{N}$ contents to DIN concentrations in each layer (Fig. S3d). Nitrogen mineralization is inhibited while $\mathrm{N}$ immobilization is promoted by increasing DIN concentration up to $200 \mu \mathrm{mol} \mathrm{L}-1$. The decomposition rate constants $k$ are regulated by substrate quality $(q)$, soil moisture $\left(\mathrm{fm}_{\mathrm{dec}}\right)$, soil temperature ( $\left.f T_{\mathrm{dec}}\right)$ and inhibition factors accounting for the decrease in Gibbs free energy due to the accumulation of end products (i.e. $\mathrm{CO}_{2}, \mathrm{CH}_{4}$ ) in the saturated soils (Appendix A, Eq. A87). The decrease in $k$ with depth is modeled based on the "peat inactivation concept" (Blodau et al., 2011) rather than only linked to anoxia (Frolking et al., 2002) or redox potential (Zhang, 2002), as in other models. The essential idea of this concept is that the transport rate of decomposition products controls the decomposition rate in the saturated 
anoxic soils (Fig. S3). The inhibitions factors are values between 0 and 1 based on $\mathrm{CO}_{2}$ and $\mathrm{CH}_{4}$ concentrations according to the inverse modeling results in Blodau et al. (2011) (Fig. S3a and b).

The intrinsic decomposability of the substrate $(L$ or $R)$ determines the base decomposition rate constant $\left(k_{\mathrm{Cpot}}\right)$. Due to the conceptual inconsistency of $k_{\text {Cpot }}$ in experiments (Updegraff et al., 1995; Bridgham et al., 1998), we calibrated the values of $k_{\text {Cpot }}$ from the long-term simulations in the spin-up runs. The moisture and temperature effect on the decomposition is each pool is modeled similar to the PCARS model (Frolking et al., 2002), with the $Q_{10}$ value of the decomposition of $L$ pools (2.3) smaller than of that of $R$ pools (3.3) (Conant et al., 2008, 2010).

\subsection{Submodel 4 - dissolved C and N}

The model contains 3 dissolved $\mathrm{C}$ pools: $\mathrm{CH}_{4}, \mathrm{CO}_{2}$ and DOC and 4 dissolved $\mathrm{N}$ pools: $\mathrm{NH}_{4}^{+}, \mathrm{NO}_{3}^{-}, \mathrm{NO}_{2}^{-}$and $\mathrm{DON}$ in each belowground layer (Fig. 2). Because decomposition proceeds and is controlled through the SOM pools, DOC and DON are considered to be an end product, and are only removed by runoff. The production of DOC, DIC, DON and $\mathrm{NH}_{4}^{+}$are inputs from the SOM and the vegetation submodels. The production of DIC is further partitioned into the production of $\mathrm{CH}_{4}$ and $\mathrm{CO}_{2}$ in the anoxic layers.

The partitioning of respired $\mathrm{C}$ into $\mathrm{CO}_{2}$ and $\mathrm{CH}_{4}$ in the saturated layers depends on the presence of alternative electron acceptors (i.e. $\mathrm{SO}_{4}^{2-}, \mathrm{NO}_{3}^{-}$and likely humic substances) for the terminal electron accepting processes (TEAP) (Conrad, 1999; Lovley and Coates, 2000). In previous studies, the ratio of $\mathrm{CO}_{2} / \mathrm{CH}_{4}$ production and the production rates of $\mathrm{CH}_{4}$ was modeled as a function of WT depth (Potter, 1997; Zhuang, 2004), or by microbial activities using MichaelisMenten kinetics (Segers and Kengen, 1998; Lopes et al., 2011). Following the concept put forward by Blodau (2011), we modeled the $\mathrm{CH}_{4}$ production rate by an energy-limited Michaelis-Menten kinetics.

We built an equation group based on the valance balance of the overall oxidation-reduction process and the mass balance of C (Appendix A, Eq. A121). The first equation (Appendix A, Eq. A121) denotes that $\mathrm{CO}_{2}$ and $\mathrm{CH}_{4}$ are the only inorganic $\mathrm{C}$ products (DIC) from the decomposition of SOM. The second equation was deduced from the valance balance of $\mathrm{CO}_{2}(+4)$ production and $\mathrm{CH}_{4}(-4)$ production from organic $\mathrm{C}$, assuming an initial oxidation state of zero as found in carbohydrates. The production of $\mathrm{CO}_{2}\left(\mathrm{CO}_{2} \mathrm{pro}_{i}\right)$ is the result of the stoichiometric release of $\mathrm{CH}_{4}\left(\mathrm{CH}_{4} \mathrm{pro}_{i}\right)$ from fermentation and subsequent methanogenesis, and the consumption of electron acceptors $\left(\mathrm{CO}_{2}\right.$ pro $\left.\mathrm{EA}_{i} i\right)$ in units of electron equivalents. The acronym EA represents electron acceptors other than $\mathrm{CO}_{2}$, including $\mathrm{NO}_{3}^{-}, \mathrm{SO}_{4}^{2-}$, and humic substances (HS).

In anaerobic systems, electron acceptors are consumed by terminal electron accepting processes that competitively consume $\mathrm{H}_{2}$ or acetate. Individual processes predominate according to their respective Gibbs free energy gain, usually in the sequence $\mathrm{NO}_{3}^{-}, \mathrm{Fe}(\mathrm{III})$, humic substances (HS), $\mathrm{SO}_{4}^{2-}$ and $\mathrm{CO}_{2}$ (Conrad, 1999; Blodau, 2011). Owing to the extremely fast turnover of $\mathrm{H}_{2}$ pools in peat, the MichaelisMenten approach is not suitable for modeling $\mathrm{CH}_{4}$ production in models running on a daily time step when $\mathrm{H}_{2}$ is considered the substrate. To avoid modeling the pools of $\mathrm{H}_{2}$ and acetate explicitly, the current model with daily time step focuses on the electron flow from complex organic matter to all TEAPs, instead of modeling each microbial process explicitly. In ombrotrophic systems like bogs, only $\mathrm{SO}_{4}^{2-}, \mathrm{NO}_{3}^{-}$and $\mathrm{HS}$ are considered relevant electron acceptors. The $\mathrm{CO}_{2}$ production from $\mathrm{SO}_{4}^{2-}$ and $\mathrm{NO}_{3}^{-}$reduction are calculated from the valance relations (Appendix A, Eq. A122), One mole of $\mathrm{SO}_{4}^{2-}$ being reduced to $\mathrm{HS}^{-}$provides 8 mole of electrons $(\mathrm{S}(+6) \rightarrow \mathrm{S}(-2))$ and 1 mole of $\mathrm{NO}_{3}^{-}$release 5, 4 and 3 moles of electrons when being reduced to $\mathrm{NO}, \mathrm{N}_{2} \mathrm{O}$ or $\mathrm{N}_{2}$ $(\mathrm{N}(+5) \rightarrow \mathrm{N}(+3) \rightarrow \mathrm{N}(+1) \rightarrow \mathrm{N}(0))$.

Humic substances have recently also been identified as electron acceptors (Lovley et al., 1996; Heitmann et al., 2007; Keller et al., 2009) and require some consideration. Reduction of humic substances may be a significant $\mathrm{CO}_{2}$ source in anoxic peat, where a large fraction of the total $\mathrm{CO}_{2}$ production typically cannot be explained by consumption of known electron acceptors (Vile et al., 2003b). Although peat stores a large amount of organic carbon as humics, likely only a small fraction of it is redox active (Roden et al., 2010). The redox-active moieties in humics have been identified as quinones, here called DOM-Q (Scott et al., 1998). Electron accepting rate constants of HS in sediments were reported to be $0.34 \mathrm{~h}^{-1}$ and $0.68 \mathrm{~h}^{-1}$ based on two oxidized humic pools (Roden et al., 2010). Field measurements reported minimum electron transfer of $0.8 \mathrm{mmol}$ charge (eq.) $\mathrm{m}^{-2} \mathrm{day}^{-1}$ generating $\mathrm{CO}_{2}$ at $0.2 \mathrm{mmol} \mathrm{m}^{-2}$ day $^{-1}$ (Heitmann et al., 2007). This rate was similar to the small production rate of $\mathrm{CH}_{4}$ at the investigated bog site.

Based on this limited information, we conceptually modeled the reduction and oxidation of humic substances using first order kinetics (Appendix A, Eqs. A133-136). The initial values of the EA (electron acceptors) and ED (electron donors) pools in the humic substances are calculated from the SOM C pool by a ratio of 1.2 eq. $(\mathrm{mol} \mathrm{C})^{-1}$ (Roden et al., 2010). The initial electron accepting capacity used in the model was ca. $2000-4000 \mathrm{mmol}$ charge $\mathrm{m}^{-2}$ for the upper $60 \mathrm{~cm}$ of peat per $\mathrm{m}^{2}$, which is close to the capacity of $2725 \mathrm{mmol}$ charge $\mathrm{m}^{-2}$ derived from a drying and rewetting experiments in a minerotrophic fen (Knorr and Blodau, 2009).

In the model electron acceptors are renewed via two mechanisms: direct oxidation by $\mathrm{O}_{2}$ due to WT fluctuation in the only temporarily saturated layers and microbially mediated electric currents through the peat column via an extracellular electron transfer $\left(I_{\text {nanowire }}\right)$. While the first mechanism is 
well documented (Knorr and Blodau, 2009), the second is speculative. It relates to the observation that even in deeper peats, that are not affected by influx of oxygen or other inorganic electron acceptors, $\mathrm{CO}_{2}$ seems to be net released in excess of methane (Beer and Blodau, 2007). This finding has remained enigmatic because excess $\mathrm{CO}_{2}$ release would be impossible from a stoichiometric point of view when organic matter with oxidation state close to zero is respired and other, more reduced decomposition products, in particular molecular hydrogen, are not concurrently released. A relevant accumulation of molecular hydrogen has, to our knowledge, not been observed in affected peats. Anaerobic methane oxidation may appear as a way out of the dilemma; however, also this process would depend on the elusive electron acceptor (Smemo and Yavitt, 2011).

Recently an extracellular electron transfer was described that has the potential to solve this enigma. Microorganisms in soils and sediments were first detected extracellularly utilizing electrons from redox active species, such as HS, and Fe (III) (Lovley and Coates, 2000). The term "microbial nanowire" was proposed later for this extracellular electron transfer (Reguera et al., 2005). Recently the process was demonstrated to occur in marine sediments over macroscopic distances (Nielsen et al., 2010). The authors suggested that electrons can extracellularly flow in interconnected networks of "nanowires" so that oxidation and reduction process are spatially separated from each other. In our case the oxidation process releasing $\mathrm{CO}_{2}$ would proceed deeper into the peat, whereas the reduction reaction would take place near the peatland surface where oxygen is present. We suppose that this mechanism may be the reason for some of the frequently observed $\mathrm{CO}_{2}$ production that is unrelated to physical supply of an electron acceptor deeper into the peat. Not knowing about mechanistic detail in peats, we conceptualized this process by simply calculating an extracellular electron current in the peat and using Ohm's law for the anoxic layers (Appendix A, Eq. A137). Peat electron flow resistance $(R)$ is determined by inverse modeling based on the resistance constant definition and corrected for soil moisture under the assumption that air-filled pore space cannot conduct electrons (Appendix A, Eq. A142). The parameter $\widetilde{n}_{\text {peat }}(\grave{\mathrm{U}} \mathrm{m})$ is the specific resistance of the material and $l$ is the layer depth (m). Electron current in $\mathrm{mA}$ was then converted to mmol by the Avogadro constant (NA) and the Faraday constant (F) (96490 Coulombs mol-1) (Appendix A, Eq. A137). To make this process work, electrochemical potential gradients (dEh) that drive the flow between adjacent layers are needed. In absence of meaningful measurements of redox potential of peat we calculated such a gradient from a measured redox potential gradient in the Mer Bleue Bog that was given by concentration depth profiles of dissolved $\mathrm{H}_{2}, \mathrm{CO}_{2}$, and $\mathrm{CH}_{4}$. We assumed that the redox potential gradient of this redox couple represents the minimum depth gradient in electrochemical potentials being present. Using the Nernst equation for the reaction $4 \mathrm{H}_{2}(\mathrm{aq})+\mathrm{CO}_{2}(\mathrm{aq}) \rightarrow 2 \mathrm{H}_{2} \mathrm{O}(\mathrm{l})+\mathrm{CH}_{4}$ (aq) (Appendix A, Eqs. A138-A141), concentration profiles were converted into electrochemical potential gradients with depth. $\mathrm{H}_{2}$ concentration was measured by Beer and Blodau for the Mer Bleue bog (2007) (Table S4).

In the model the electron flow through the peat towards the peatland surface is used to reoxidize $\mathrm{H}_{2} \mathrm{~S}$ to sulfate and DOM- $\mathrm{QH}_{2}$ to DOM-Q at larger depths. These species are the reduced again, producing the needed "excess" $\mathrm{CO}_{2}$ in the process and lowering rates of methanogenesis, respectively (Appendix A, Eq. A136). The rate constant of sulfate reduction was adjusted to the suggested range of the $\mathrm{SO}_{4}^{2-}$ reduction rates based on the $\mathrm{S}$ deposition on the site at $0.89 \mathrm{mmol} \mathrm{S} \mathrm{m}^{-3} \mathrm{day}^{-1}$ (Vile, 2003a). The same thermodynamic inhibition concept as used to model methanogenesis was applied also to bacterial sulfate reduction (Appendix A, Eq. A129).

Both $\mathrm{CO}_{2}$ and $\mathrm{CH}_{4}$ are in equilibrium between gaseous phase and dissolved phase obeying Henry's Law (Appendix A, Eqs. A100-A103). The efflux of $\mathrm{C}$ and $\mathrm{N}$ are through runoff and advection in dissolved phase and in gaseous phase from the soil surface. Diffusion follows Fick's law with moisture-corrected coefficients in the saturated layers and was modeled as step functions in the unsaturated layers where diffusion accelerates by orders of magnitude for gases (Appendix A, Eqs. A104-A107). $\mathrm{CH}_{4}$ also escapes from the soil via ebullition and plant-mediated transportation (Appendix A, Eqs. A115-A120). Ebullition occurs in saturated layers once $\mathrm{CH}_{4}$ level exceeds the maximum concentration $\mathrm{CH}_{4, \text { max }}$. The parameter $\mathrm{CH}_{4, \max }$ is sensitive to temperature and pressure (Davie et al., 2004), with a base maximum $\mathrm{CH}_{4}$ concentration at $500 \mathrm{uM}$, which is the value for a vegetated site at $10^{\circ} \mathrm{C}$ in Walter et al. (2001). The ebullition of $\mathrm{CH}_{4}$ releases the gas to the atmosphere without it passing through the unsaturated zone. In the rooted layers, graminoids transport $\mathrm{CH}_{4}$ at rates that are determined by the biomass of the graminoid roots. A percentage of $50 \%$ of the $\mathrm{CH}_{4}$ are oxidized to $\mathrm{CO}_{2}$ during the plantmediated transportation by the $\mathrm{O}_{2}$ in plant tissues (Walter et al., 2001). The $\mathrm{CH}_{4}$ oxidation in the oxic layers was modeled using temperature-sensitive double Michaelis-Menten functions (Segers and Leffelaar, 2001) (Appendix A, Eq. A118).

The gases $\mathrm{N}_{2} \mathrm{O}$ and $\mathrm{NO}$ are byproducts of nitrification and denitrification $\left(\mathrm{NH}_{4}^{+} \rightarrow \mathrm{NO}_{2}^{-} \rightarrow \mathrm{NO}_{3}^{-} \rightarrow \mathrm{NO}_{2}^{-} \rightarrow \mathrm{NO} \rightarrow \mathrm{N}_{2} \mathrm{O} \rightarrow \mathrm{N}_{2}\right)$ in the oxic and anoxic layers, respectively. During nitrification, the fraction of $\mathrm{N}$ loss as $\mathrm{NO}\left(r \mathrm{NO}_{\text {nitri }}\right)$ is $0.1 \%-4 \%$ day $^{-1}$ with a mean value of $2 \%$ (Baumgärtner and Conrad, 1992; Parsons et al., 1996). For $\mathrm{N}_{2} \mathrm{O}\left(r \mathrm{~N}_{2} \mathrm{O}_{\text {nitri }}\right)$ this value is smaller at $0.1 \%-0.2 \%$ day $^{-1}$ (Ingwersen et al., 1999; Breuer et al., 2002; Khalil et al., 2004a). We used similar values as in the model DNDC for acid ecosystems, where $r \mathrm{~N}_{2} \mathrm{O}_{\text {nitri }}$ was $0.06 \%$ and $r \mathrm{NO}_{\text {nitri was }} 0.25 \%(\mathrm{Li}$ and Aber, 2000). Both nitrification and denitrification are regulated by temperature, moisture, and $\mathrm{pH}$. Moisture is the 
Table 1. State variables in the model.

\begin{tabular}{|c|c|c|c|c|c|c|}
\hline State Variables & Description & Units* & Eq. No. & \multicolumn{3}{|c|}{ Initial Values } \\
\hline \multicolumn{7}{|c|}{ Environment } \\
\hline WS & $\begin{array}{l}\text { Water content in the upper } 1 \mathrm{~m}^{3} \\
\text { of Peat }\end{array}$ & $\mathrm{m}^{3}$ & Eq. (A1) & \multicolumn{3}{|c|}{0.4} \\
\hline $\mathrm{O}_{2, i}$ & $\mathrm{O}_{2}$ content layer $\mathrm{i}$ & mmol & Eq. (A12) & \multicolumn{3}{|c|}{0} \\
\hline Wccap & Moss capitulum water content & $\mathrm{g} \mathrm{H}_{2} \mathrm{O}$ g dry mass ${ }^{-1}$ & Eq. (A16) & \multicolumn{3}{|c|}{5} \\
\hline \multicolumn{3}{|c|}{ Vegetation } & & Moss & Gram. & Shrub \\
\hline $\mathrm{C}_{\text {sh, struc, }, j}$ & Shoot structural C of PFT $\mathrm{j}$ & $\mathrm{gC}$ & Eq. (A33) & 70.45 & 8.05 & 121.20 \\
\hline $\mathrm{C}_{\mathrm{rt}, \text { struc }, j}$ & Root structural C of PFT j & $\mathrm{gC}$ & Eq. (A33) & 0 & 18.67 & 542.84 \\
\hline $\mathrm{N}_{\mathrm{sh}, \text { struc }, j}$ & Shoot structural $\mathrm{N}$ in PFT $\mathrm{j}$ & $\mathrm{gN}$ & Eq. (A33) & 1.44 & 0.18 & 2.45 \\
\hline $\mathrm{N}_{\mathrm{rt}, \text { struc }, j}$ & Root structural $\mathrm{N}$ in PFT j & $\mathrm{gN}$ & Eq. (A33) & 0 & 0.41 & 11.04 \\
\hline $\mathrm{C}_{\text {sh, subs, } j}$ & Shoot substrate $\mathrm{C}$ of $\mathrm{PFT} \mathrm{j}$ & $\mathrm{gC}$ & Eq. (A37) & 31.34 & 0.16 & 57.67 \\
\hline $\mathrm{C}_{\mathrm{rtsubs}, j}$ & Root substrate $\mathrm{C}$ of PFT j & $\mathrm{gC}$ & Eq. (A59) & 0 & 0.02 & 15.69 \\
\hline $\mathrm{N}_{\text {sh, subs, } j}$ & Shoot substrate $\mathrm{N}$ in PFT $\mathrm{j}$ & $\mathrm{gN}$ & Eq. (A62) & 0.1 & 0.07 & 0.07 \\
\hline $\mathrm{N}_{\mathrm{rt}, \text { subs }, j}$ & Root substrate $\mathrm{N}$ in PFT j & $\mathrm{gN}$ & Eq. (A70) & 0 & 0.2 & 0.63 \\
\hline \multicolumn{7}{|c|}{ Soil organic matter } \\
\hline $\mathrm{SOM} \mathrm{C}_{L, i}$ & SOM Labile $\mathrm{C}$ in Layer i & $\mathrm{gC}$ & Eq. (A78) & \multicolumn{3}{|c|}{ Table S4 } \\
\hline $\mathrm{SOM} \mathrm{C}_{R, i}$ & SOM recalcitrant $\mathrm{C}$ in layer $\mathrm{i}$ & $\mathrm{gC}$ & Eq. (A78) & \multicolumn{3}{|c|}{ Table S4 } \\
\hline $\operatorname{SOM~N}_{L, i}$ & SOM labile $\mathrm{N}$ in layer $\mathrm{i}$ & $\mathrm{gN}$ & Eq. (A78) & \multicolumn{3}{|c|}{ Table S4 } \\
\hline $\mathrm{SOM} \mathrm{N}_{R, i}$ & SOM recalcitrant $\mathrm{N}$ in layer i & $\mathrm{gN}$ & Eq. (A78) & \multicolumn{3}{|c|}{ Table S4 } \\
\hline \multicolumn{7}{|c|}{ Dissolved $\mathrm{C}$ and $\mathrm{N}$} \\
\hline $\mathrm{DOC}_{i}$ & DOC Content of layer i & mmol & Eq. (A108) & \multicolumn{3}{|c|}{0} \\
\hline $\mathrm{CO}_{2, i}$ & $\mathrm{CO}_{2}$ Content of layer i & mmol & Eq. (A110) & \multicolumn{3}{|c|}{ Table S4, Eq. (A23) } \\
\hline $\mathrm{CH}_{4, i}$ & $\mathrm{CH}_{4}$ Content of layer i & mmol & Eq. (A113) & \multicolumn{3}{|c|}{ Table S4, Eq. (A23) } \\
\hline $\mathrm{DON}_{i}$ & DON Content of layer i & mmol & Eq. (A144) & \multicolumn{3}{|c|}{0} \\
\hline $\mathrm{NH}_{4}^{+}$ & $\mathrm{NH}_{4}^{+}$Content of layer i & mmol & Eq. (A146) & \multicolumn{3}{|c|}{0} \\
\hline $\mathrm{NO}_{3}^{-}$ & $\mathrm{NO}_{3}^{-}$Content of layer i & mmol & Eq. (A156) & \multicolumn{3}{|c|}{0} \\
\hline $\mathrm{NO}_{2-}^{{ }_{i}}$ & $\mathrm{NO}_{2}$ Content of layer $\mathrm{i}$ & mmol & Eq. (A159) & \multicolumn{3}{|c|}{0} \\
\hline $\mathrm{SO}_{4}^{2-}$ & $\mathrm{SO}_{4}^{2-}$ Content in Peat & mmol & Eq. (A123) & \multicolumn{3}{|c|}{63.15} \\
\hline $\mathrm{H}_{2} \stackrel{+}{\mathrm{S}}$ & $\mathrm{H}_{2} \stackrel{+}{\mathrm{S}}$ Content in Peat & mmol & Eq. (A130) & \multicolumn{3}{|c|}{1.58} \\
\hline $\mathrm{EA}_{\mathrm{HS}, i}$ & $\begin{array}{l}\text { oxidized dissolved humic sub- } \\
\text { stances as electron accepter } \\
\text { (DOM-Q) of layer i }\end{array}$ & mmol (eq.) & Eq. (A133) & \multicolumn{3}{|c|}{ Eq. (A143) } \\
\hline $\mathrm{ED}_{\mathrm{HS}, i}$ & $\begin{array}{l}\text { reduced dissolved humic } \\
\text { substances as electron donor } \\
\left(\mathrm{DOM}-\mathrm{QH}_{2}\right) \text { of layer } \mathrm{i}\end{array}$ & mmol (eq.) & Eq. (A134) & \multicolumn{3}{|c|}{ Eq. (A143) } \\
\hline
\end{tabular}

* Units were standardized to $1 \mathrm{~m}^{2}$ area of Peatlands for model output.

dominant control for nitrification and an effective control for denitrification (Linn and Doran, 1984; Riedo et al., 1998). In an acidic environment, nitrification was detected to cease below $\mathrm{pH}$ of 4 and reached a maximum at a pH of 6 (Lång et al., 1993). The optimal range of $\mathrm{pH}$ for denitrification was suggested to be from 6 to 8 (Heinen, 2006). Temperature factors were empirically modeled, using the equation in DNDC (Li and Aber, 2000) for nitrification and the common formalism equation in NEMIS (Johnsson et al., 1987; Hénault and Germon, 2008) for denitrification.

\section{Model application}

\subsection{Site description}

The model was applied on the Mer Bleue (MB) Bog for a period of $6 \mathrm{yr}$ from 1999 to 2004 to evaluate the simulation performances of WT dynamics, carbon fluxes, soil water DIC and $\mathrm{CH}_{4}$ concentrations and $\mathrm{C}$ and $\mathrm{N}$ budgets against observations.

The Mer Bleue $\operatorname{Bog}\left(45.51^{\circ} \mathrm{N}, 75.48^{\circ} \mathrm{W}\right)$ is a raised acidic ombrotrophic bog of $28 \mathrm{~km}^{2}$ located $10 \mathrm{~km}$ east of Ottawa, 
Ontario. The bog was formed $8400 \mathrm{yr}$ ago as a fen and developed into a bog between 7100 and $6800 \mathrm{yr}$ BP. The peat depth varies from 5 to $6 \mathrm{~m}$ at the center to $<0.3 \mathrm{~m}$ at the margin (Roulet et al., 2007). The vegetation coverage is dominated by mosses (e.g. Sphagnum capillifolium, S. angustifolium, S. magellanicum and Polytrichum strictum) and evergreen shrubs (e.g. Ledum groenlandicum, Chamaedaphne calyculata). Some deciduous shrubs (Vaccinium myrtilloides), sedges (Eriphorum Vaginatum), black spruce (Picea marinana) and larch also appear in some areas (Moore et al., 2002). The annual mean air temperature record from the local meteorology station is 5.8 degrees and the mean precipitation is $910 \mathrm{~mm}$ (1961-1990 average; Environmental Canada). The coldest month is January $\left(-10.8^{\circ} \mathrm{C}\right)$ and the warmest month is July $\left(20.8^{\circ} \mathrm{C}\right)$ (Lafleur, 2003).

\subsection{Application data and initialization}

Inputs required are geographic location and local slope of the site, daily precipitation and PAR, daily snow-depth record, annual average and range of air temperature, atmospheric $\mathrm{CO}_{2}, \mathrm{CH}_{4}$ and $\mathrm{O}_{2}$ levels, annual $\mathrm{N}$ load and vegetation type of the site (Table 2).

Observed C fluxes, water table depth, and the depth profiles of temperature and moisture with $5 \mathrm{~s}$ to $30 \mathrm{~min}$ intervals were obtained from fluxnet Canada (http://fluxnet.ccrp.ec.gc. ca) and averaged to daily values. Fluxes were determined using micrometeorological techniques, and gaps shorter than $2 \mathrm{~h}$ were filled by linear interpolation between the nearest measured data points. Longer gaps were filled by repeating the corresponding period of time from the closest available dates. Other data sets for model evaluation were obtained from a range of the published literature. The spin-up (initiation) of the model was conducted with initial values obtained from literature (Table S4) and the meteorological and geophysical boundary conditions (Table 2) from 1999 to 2004 obtained from fluxnet Canada. The time series was repeated every $6 \mathrm{yr}$ until the model approached its steady state after a period of longer than $100 \mathrm{yr}$. The obtained values of state variables were used for the actual model application and evaluation. Most parameters were obtained from literature for bogs or peatlands in general, or calibrated for the ranges from measurements, or in line with the values used in previously published models. In total, 29 out of 140 parameters were calibrated and ranked from 3 to 1 based on their origin and descending confidence in their accuracy and correctness (Tables 3 and 4). Parameters in category 3 were calibrated with comparison to similar parameters in references; parameters in category 2 were calibrated in comparison to conceptually related parameters in references; parameters in category 1 were unavailable in literature and thus were calibrated without references (Table 4).
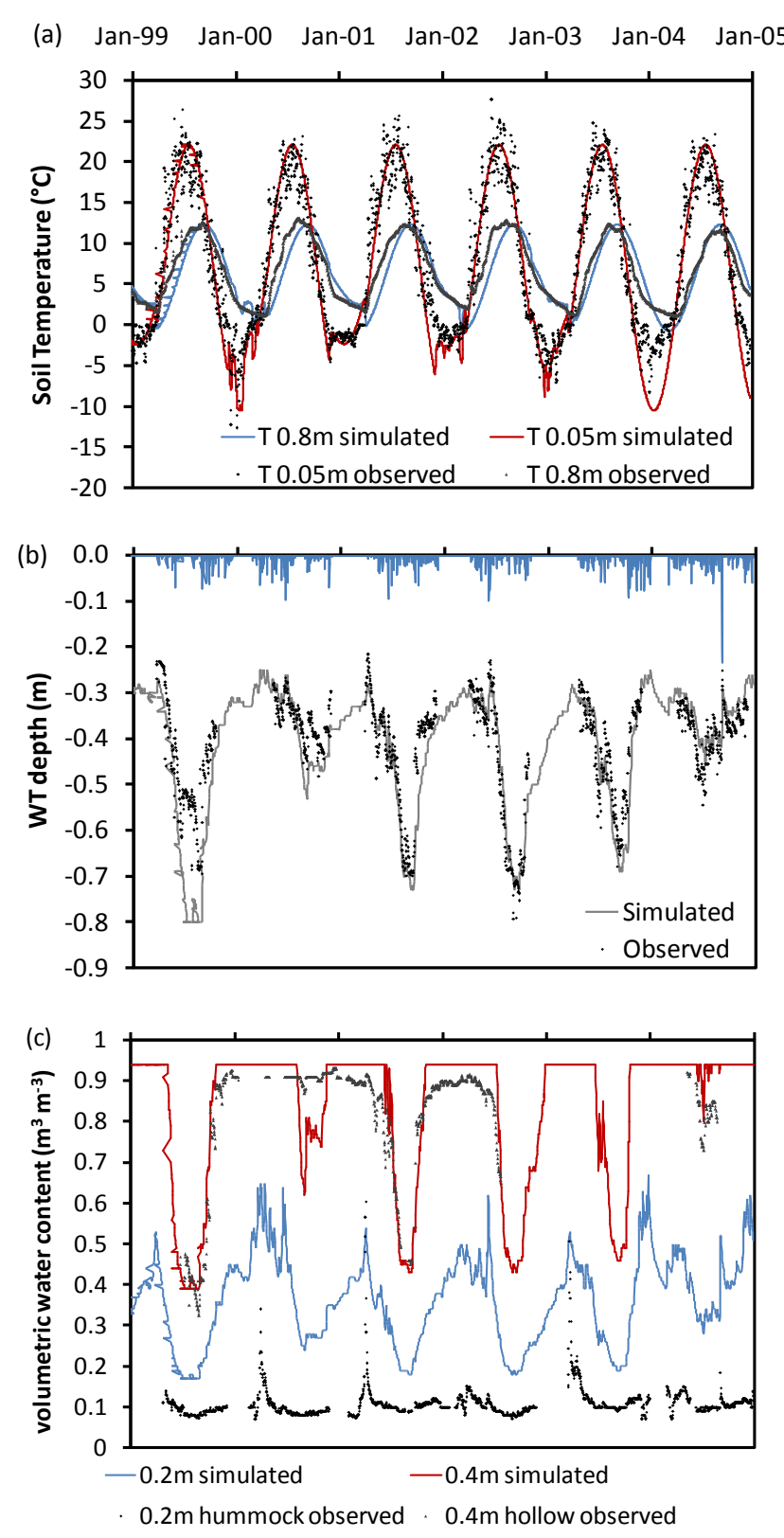

Fig. 5. Time series of observed daily average (symbols) and daily simulated (lines) of temperature (a), water table depth (b), and volumetric water content (c) for 1999-2004. The blue bars in (b) indicate observed daily precipitation records.

\section{Results}

We ran the parameterized, initiated model for $6 \mathrm{yr}$ from 1999 to 2004 and evaluated the simulation results of WT depth, and depth profiles of soil temperature, moisture and $\mathrm{O}_{2}$ to assess the ability of the model to generate environmental controls on $\mathrm{C}$ and $\mathrm{N}$ cycling. The simulated $\mathrm{C}$ and $\mathrm{N}$ pool sizes, transfer rates and fluxes were compared with six years of continuous measurements to evaluate the capability of the 
Table 2. Site-specific parameters.

\begin{tabular}{|c|c|c|c|c|}
\hline Name & Description & Value & Units & Sources \\
\hline local slope & Local slope of the site & 0.0008 & $\mathrm{~m} \mathrm{~m}^{-1}$ & Fraser et al. (2001a) \\
\hline$t_{l}$ & Day of year when the annual mean $T$ is reached & 115 & days & calculated \\
\hline$\sigma_{T}$ & Amplitude of the air $T$ sinusoidal curve & 17 & ${ }^{\circ} \mathrm{C}$ & calculated \\
\hline Latitude & Latitude of the site & $42.24^{\circ} \mathrm{N}$ & $\circ$ & - \\
\hline N load & Annual wet $\mathrm{N}$ deposition level & 0.8 & $\mathrm{gN} \mathrm{m}^{-2} \mathrm{yr}^{-1}$ & Turunen (2004) \\
\hline$r t k_{j}$ & Root distribution fraction $k$ & Gram. 0.938 Shrub 0.935 & - & Murphy et al. (2009) \\
\hline finert frac $_{j}$ & Fine root fraction of roots & Gram. 0.5 Shrub 0.2 & - & Murphy et al. (2009) \\
\hline
\end{tabular}

model in quantifying $\mathrm{C}$ and $\mathrm{N}$ pools and cycling rates. We also conducted sensitivity analysis for the key factors (e.g. temperature, precipitation, $\mathrm{N}$ deposition) and a range of uncertain calibrated parameters (e.g. potential decomposition rate of the soil organic matter). This demonstrated the sensitivity of the model to $\mathrm{N}$ availability and climate controls, which shows the potential for applying the model to longterm $\mathrm{N}$ fertilization and $\mathrm{N}$ deposition and climate change studies. As statistics for evaluation we chose the root mean square error (RMSE), linear regression coefficient $\left(r^{2}\right)$, and the index of agreement $(d)$ (Willmott, 1982).

\subsection{WT depth, soil temperature and moisture}

Simulated daily average soil temperature was plotted against measured temperatures in hummocks at $0.05 \mathrm{~m}$ and $0.8 \mathrm{~m}$ depth (Fig. 5a). The simulations agreed well with the observations and showed degrees of agreement $(d)$ of 0.97 and 0.95 , and RMSE of 3.23 and 1.70 degrees, respectively. However, the model failed to simulate the observed deviation from the sinusoidal temperature curve when snow was not present in the winter of 2003, implying other controls on soil temperature that are currently missing in the model.

In general, the simulated WT depth showed good agreement with the observed data, with a degree of agreement (d) of 0.98 and RMSE of $0.06 \mathrm{~m}$ (Fig. 5b). The largest deviation was from mid-July to early August of 1999, when the simulated WT depth for some days reached the maximum depth and was more than $20 \mathrm{~cm}$ below the observed WT depth. From 1999 to 2002, WT depth elevation was underestimated during seasonal changes from summer to fall when the deviations of more than $10 \mathrm{~cm}$ occurred for 10 to 30 days. These disparities were likely owed to the simple bucket model structure that lacks processes of water transfer that buffer variations in water content.

Considering the large variation of soil moisture between hummocks and hollows, we compared the simulation at $0.2 \mathrm{~m}$ and $0.4 \mathrm{~m}$ depth with the observations in hummock and hollows, respectively (Fig. 5c). The seasonal dynamics were well captured and the $0.4 \mathrm{~m}$ simulation agrees with the observation strongly. However, the simulated volumetric water content at $0.2 \mathrm{~m}$ was systematically overestimated by 0.1 to 0.2 in summers and up to 0.5 for the wettest year in winter.
Large spatial in situ variability of observed volumetric water content might be one of the reasons for this large discrepancy, as the simulated values are similar to other measurements in hummocks in the Mer Bleue Bog during even drier years (Wendel et al., 2011).

\subsection{Daily Carbon fluxes}

Gross ecosystem production (GEP) was calculated as the sum of simulated gross primary production (GPP) of all PFTs (Fig. 6a). The simulated ecosystem respiration (ER) was the release of $\mathrm{CO}_{2}$ gas from the peat surface, which included autotrophic respiration (AR) in shoots and roots of plants and the heterotrophic respiration (HR) of microorganisms in the soil (Fig. 6b). Net ecosystem exchange (NEE) was calculated as the difference between ER and GPP (Fig. 6c).

Overall, the simulated GPP, ER and NEE captured the seasonal dynamics and the magnitudes of the $\mathrm{C}$ fluxes. The maximum simulated daily GPP was $5.96 \mathrm{gC} \mathrm{m}^{-2}$ day $^{-1}$ and occurred in the driest year 1999, which is similar to the maximum observed $6.80 \mathrm{gC} \mathrm{m}^{-2} \mathrm{day}^{-1}$. The simulated starting dates of spring PSN ranged from day 79 (2000) to day 99 (2001), with an average date of day 90 . These values fell in the reported range from day 86 to day 101 (Moore et al., 2006). The simulated starting dates of PSN in 2001 and 2003 were at day 99 and 84, which was two days earlier than in field observations. The average difference between simulated and observed GPP was $0.43 \mathrm{gC} \mathrm{m}^{-2} \mathrm{day}^{-1}$, which was slightly larger than the calculated mean error of GPP $\left( \pm 0.11 \mathrm{gCO}_{2} \mathrm{~m}^{-2} \mathrm{day}^{-1}\right)$ in measurements (Moore et al., 2006). Statistical analysis revealed a root mean square error (RMSE) of $0.73 \mathrm{gC} \mathrm{m}^{-2} \mathrm{day}^{-1}$ and a degree of agreement (d) of 0.95 (Fig. 7a). However, there were a few days when the simulation errors were large, among which the maximum underestimation was $3.68 \mathrm{gC} \mathrm{m}^{-2}$ day $^{-1}$ on 31 July in 2000 and the maximum overestimation was $3.21 \mathrm{gC} \mathrm{m}^{-2} \mathrm{day}^{-1}$ on 23 May 2002.

ER simulation followed a seasonal trend with winter values being smaller than $1 \mathrm{gC} \mathrm{m}^{-2} \mathrm{day}^{-1}$ and summer peaks of 5 to $7 \mathrm{gC} \mathrm{m}^{-2} \mathrm{day}^{-1}$. The summer peaks were higher than the field estimates from 2.07 to $4.67 \mathrm{gC} \mathrm{m}^{-2} \mathrm{day}^{-1}$, the latter was however likely to be underestimated by $20 \%$ on average considering the measuring and calculation 
Table 3. Referenced Parameters.

\begin{tabular}{|c|c|c|c|c|c|c|}
\hline Name & Description & & Value & & Unit & Source \\
\hline \multicolumn{7}{|c|}{ Environment } \\
\hline$k_{\text {transm, } a}$ & Parameter $a$ for transmissivity & & 1.98 & & - & 1 \\
\hline$K_{\text {transm }, b}$ & Parameter $b$ for transmissivity & & 24.38 & & - & 1 \\
\hline $\mathrm{EPT} \_r_{\text {moss }}$ & $\begin{array}{l}\text { Rate constant of capitulum water Loss to evap- } \\
\text { otranspiration }\end{array}$ & & 0.24 & & day $^{-1}$ & 2 \\
\hline Plant & & Moss & Gram. & shrub & & \\
\hline$P_{\max , 20}$ & Light saturated PSN rate at $20^{\circ} \mathrm{C}$ & 2 & 2 & 5 & $\mathrm{mgCO}_{2} \mathrm{~m}^{-2} \mathrm{~s}^{-1}$ & $3,4,5$ \\
\hline$K_{\mathrm{CO} 2, P \max }$ & $\begin{array}{l}\text { Parameter of } \mathrm{CO}_{2} \text { effect on } P_{\max } \text { at } 700 \mathrm{vpm} \\
\mathrm{CO}_{2}, 20^{\circ} \mathrm{C}, 1 \mathrm{~atm}\end{array}$ & & 0.00128 & & $\mathrm{kgCO}_{2} \mathrm{~m}^{-3}$ & 6 \\
\hline $\mathrm{Na}_{\max , j}$ & Maximum $\mathrm{N}$ content in leaf & 1.5 & 3 & 3 & $\mathrm{gN} \mathrm{m}^{-2}$ & 10,11 \\
\hline$T_{\max , j}$ & Maximum temperature for PSN & 30 & 35 & 35 & ${ }^{\circ} \mathrm{C}$ & 2,6 \\
\hline$T_{\min , j}$ & Minimum temperature for PSN & -1 & -3 & -5 & ${ }^{\circ} \mathrm{C}$ & 2,6 \\
\hline$m f T$ & Multiplier of temperature effect & & 2 & & ${ }^{\circ} \mathrm{C}$ & 6 \\
\hline$T_{\text {ref }, j}$ & Temperature when $f_{T, \mathrm{PSN}}$ is 1 & 22 & 25 & 25 & ${ }^{\circ} \mathrm{C}$ & 6,12 \\
\hline$q_{f T}$ & $Q_{10}$ of temperature effect & & 2 & & & 6 \\
\hline$\alpha_{0}$ & PSN efficiency at $15^{\circ} \mathrm{C}, 1 \mathrm{~atm}$ & & 2.2 & & $\mu \mathrm{gCO}_{2} \mathrm{~m}^{-2} \mathrm{~s}^{-1}$ & 6 \\
\hline$P$ conc $_{\text {moss }}$ & Moss $P$ concentration & & 0.001 & & $\mathrm{gP} \mathrm{g}^{-1}$ & $* 13$ \\
\hline CNDOM & $\mathrm{C} / \mathrm{N}$ ratio of $\mathrm{DOM}$ & & 40 & & $\mathrm{gC} \mathrm{gN}^{-1}$ & 14 \\
\hline Cconc $_{j}$ & Structural C concentration & 0.44 & 0.46 & 0.51 & $\mathrm{gC} \mathrm{g}^{-1}$ & 15 \\
\hline$K_{\text {ext }, j}$ & Light extinction coefficient & 0.95 & 0.5 & 0.96 & - & $7,16,17$ \\
\hline $\operatorname{SLA}_{j}$ & Specific leaf area & 0.02 & 0.012 & 0.01 & $\mathrm{~m}^{2} \mathrm{~g}^{-1}$ & $18,19,20$ \\
\hline$\xi_{j}$ & Curve of PSN and PAR parameter & 0.99 & 0.9 & 0.7 & - & 7 \\
\hline$r R m_{\text {leaf }, j}$ & Leaf maintenance respiration rate constant & 12 & 5 & 5 & $\mathrm{gC} \mathrm{kgC}^{-1}$ day $^{-1}$ & $* 21$ \\
\hline$r R m_{\text {stem, } j}$ & Stem maintenance respiration rate constant & 10 & 2.5 & 2.5 & $\mathrm{gC} \mathrm{kgC}^{-1}$ day $^{-1}$ & $* 21$ \\
\hline$r R m_{\text {coarsert }, j}$ & $\begin{array}{l}\text { Coarse root maintenance respiration rate con- } \\
\text { stant }\end{array}$ & & 0.001 & & day $^{-1}$ & 21 \\
\hline$r R m_{\text {finert, } j}$ & $\begin{array}{l}\text { Fine root maintenance respiration rate con- } \\
\text { stant }\end{array}$ & & 0.0048 & & day $^{-1}$ & 22 \\
\hline$Q_{10, X, r, j}$ & $Q_{10}$ of temperature effect on respiration & 2 & 1.7 & 1.8 & - & $23,24,25$ \\
\hline $\mathrm{li}_{-} C_{-} \mathrm{frac}_{X, \mathrm{subs}, j, \min }$ & Minimum substrate $\mathrm{C}$ fraction of litter & & 0.3 & & - & 26 \\
\hline$k_{\text {li subsC }}$ & Constant for substrate $\mathrm{C}$ in litter & & 0.05 & & $\mathrm{gC} \mathrm{g}^{-1}$ & 26 \\
\hline CNratio $_{\text {rec }}$ & $\mathrm{CN}$ ratio of recycled litter & & 2.7 & & ${\mathrm{gC} \mathrm{gN}^{-1}}^{-1}$ & 8 \\
\hline CNratio $_{\text {upt }}$ & $\mathrm{CN}$ ratio of DOM uptake & & 2.7 & & ${\mathrm{gC} \mathrm{gN}^{-1}}^{-1}$ & $* * 8$ \\
\hline$k_{\text {rec_subsN }}$ & Constant of recycled substrate $\mathrm{N}$ from litter & & 0.01 & & $\mathrm{gN} \mathrm{g}^{-1}$ & 8 \\
\hline$r_{-}$growth $_{\mathrm{sh}, j}$ & Shoot growth rate constant & 0.5 & 0.5 & 0.4 & $\operatorname{day}^{-1}$ & $* 8,16$ \\
\hline$r_{-}$growth $_{\mathrm{rt}, j}$ & Root growth rate constant & & 0.2 & & day $^{-1}$ & $* 26$ \\
\hline$K_{m}$ growC $_{j}$ & $\begin{array}{l}\text { Half saturation constant for substrate } \mathrm{C} \text { in } \\
\text { biomass growth }\end{array}$ & 0.1 & 0.1 & 0.05 & $\mathrm{gC}^{-1}$ & $* 26$ \\
\hline$K_{m}$ growN $_{j}$ & $\begin{array}{l}\text { Half saturation constant for substrate } \mathrm{N} \text { in } \\
\text { biomass growth }\end{array}$ & 1 & 10 & 1 & $\mathrm{gN} \mathrm{kg}^{-1}$ & $* 26$ \\
\hline$\rho_{\mathrm{C}, j}$ & $\begin{array}{l}\text { resistance parameter for shoot root transport of } \\
\text { substrate C }\end{array}$ & - & 10 & 60 & $\mathrm{~m}^{2}$ day $\mathrm{g}^{-1}$ & $* 9$ \\
\hline$\rho_{\mathrm{N}, j}$ & $\begin{array}{l}\text { resistance parameter for shoot root transport of } \\
\text { substrate } \mathrm{N}\end{array}$ & - & 5 & 5 & $\mathrm{~m}^{2}$ day $\mathrm{g}^{-1}$ & $* 9$ \\
\hline li_rec_Nfrac $X$, subs, $j, \max$ & $\begin{array}{l}\text { Maximum recycled fraction of substrate } \mathrm{N} \\
\text { from litter }\end{array}$ & 0.5 & 0.4 & 0.8 & - & $* 8$ \\
\hline frac_li_N $\mathrm{N}_{X, \text { subs, } j, \min }$ & Minimum substrate $\mathrm{N}$ fraction of litter & 0.2 & 0.3 & 0.1 & - & $* 8$ \\
\hline$k_{\text {li_subsN }}$ & Constant of substrate $\mathrm{N}$ in litter & & 0.005 & & $\mathrm{gN} \mathrm{g}^{-1}$ & $* 8$ \\
\hline$k_{\mathrm{m}, \mathrm{NO} 3}$ & Half saturation constant of $\mathrm{NO}_{3}^{-}$uptake & & 10 & & $\mathrm{mmol} \mathrm{m}^{3}$ & 27 \\
\hline$k_{\mathrm{m}, \mathrm{NH} 4}$ & Half saturation constant of $\mathrm{NH}_{4}^{+}$uptake & & 50 & & $\mathrm{mmol} \mathrm{m} \mathrm{m}^{3}$ & 27 \\
\hline$V_{\mathrm{m}, \mathrm{NO} 3}$ & Maximum rate of $\mathrm{NO}_{3}^{-}$uptake & & 0.00221 & & $\mathrm{mmol} \mathrm{cm}^{-2}$ day $^{-1}$ & 27,28 \\
\hline $\mathrm{V}_{\mathrm{m}, \mathrm{NH} 4}$ & Maximum rate of $\mathrm{NH}_{4}^{+}$uptake & & 0.000432 & & $\mathrm{mmol} \mathrm{cm}-2$ day $^{-1}$ & 27,28 \\
\hline$Q_{10, \text { NO3upt }}$ & $Q_{10}$ for $\mathrm{NO}_{3}^{-}$uptake & & 1.86 & & - & 29 \\
\hline$k_{\mathrm{m}, \mathrm{c}, \mathrm{Nupt}}$ & $\begin{array}{l}\text { Constant of substrate } \mathrm{C} \text { concen-tration on } \mathrm{N} \\
\text { uptake in plants }\end{array}$ & & 0.1 & & $\mathrm{gC} \mathrm{g}^{-1}$ & $* 30$ \\
\hline$K_{\mathrm{m}, \mathrm{N}, \mathrm{Nupt}}$ & $\begin{array}{l}\text { Constant of substrate } \mathrm{N} \text { concen-tration on } \mathrm{N} \\
\text { uptake in plants }\end{array}$ & & 0.005 & & $\mathrm{gN} \mathrm{g}^{-1}$ & 8 \\
\hline$V_{\mathrm{m}, \mathrm{DON}, j}$ & Maximum rate of DON uptake & - & $10^{-8}$ & 0.01 & $\mathrm{mmol} \mathrm{g}^{-1}$ day $^{-1}$ & $* 30$ \\
\hline$K_{\mathrm{m}, \mathrm{DON}, j}$ & Half saturation constant of DON for uptake & - & 141 & 111 & $\mathrm{mmol} \mathrm{m}^{-3}$ & 30 \\
\hline
\end{tabular}


Table 3. Continued.

\begin{tabular}{|c|c|c|c|c|}
\hline SOM & & & & \\
\hline $\mathrm{CN}_{\mathrm{mo}}$ & Microbial $\mathrm{C} / \mathrm{N}$ ratio & 7 & $\mathrm{gC} \mathrm{gN}^{-1}$ & 31 \\
\hline$T_{\text {min,dec }}$ & $\begin{array}{l}\text { Minimum temperature for SOM } \\
\text { decomposition }\end{array}$ & -4 & ${ }^{\circ} \mathrm{C}$ & 31 \\
\hline$Q_{10, \operatorname{dec}, q}$ & $\begin{array}{l}Q_{10} \text { of temperature effects on the } \\
\text { decomposition of labile or recalcitrant SOM }\end{array}$ & $Q_{10, \mathrm{~L}}=2.3, Q_{10, \mathrm{R}}=3.3$ & & 33 \\
\hline $\mathrm{LeaDOC}_{i}$ & Fraction of SOM leach as DOC & 0.05 & - & $* 31$ \\
\hline $\mathrm{LeaDON}_{i}$ & Fraction of SOM leach as DON & 0.05 & - & $* 31$ \\
\hline $\mathrm{CN}_{\text {limit }}$ & $\begin{array}{l}\text { The asymptotic CN ratio value of SOM } \\
\text { decomposition }\end{array}$ & 20 & ${\mathrm{gC} \mathrm{gN}^{-1}}^{-1}$ & 31 \\
\hline \multicolumn{5}{|l|}{ Dissolved } \\
\hline Oxi_frac $_{i}$ & $\begin{array}{l}\text { Fraction of } \mathrm{CH}_{4} \text { oxidized during plant } \\
\text { transportation }\end{array}$ & 0.5 & - & 34 \\
\hline$V_{\mathrm{m}, \mathrm{CH} 4 \mathrm{oxi}}$ & Maximum oxidation rate of $\mathrm{CH}_{4}$ & 63.93 & $\mathrm{mmol} \mathrm{m}^{-3}$ day $^{-1}$ & 34 \\
\hline$K_{\mathrm{mCH} 4 \mathrm{oxi}}$ & Half saturation constant of $\mathrm{CH}_{4}$ oxidation & 29 & $\mathrm{mmol} \mathrm{m}^{-3}$ & 35 \\
\hline$Q_{10, \mathrm{CH} 4 \mathrm{oxi}}$ & $Q_{10}$ for $\mathrm{CH}_{4}$ oxidation & 2 & & 34 \\
\hline$k_{\mathrm{ebu}}$ & Ebullition rate constant of $\mathrm{CH}_{4}$ & 0.01 & day $^{-1}$ & $* 34$ \\
\hline DON\%dep & Fraction of DON in deposited N & 0.4 & - & $* 13$ \\
\hline$Q_{10, \mathrm{Nfix}}$ & $Q_{10}$ for $\mathrm{N}_{2}$ fixation & 3 & - & 36 \\
\hline$T \min _{\mathrm{Nfix}}$ & Minimum temperature for $\mathrm{N}_{2}$ fixation & -4 & ${ }^{\circ} \mathrm{C}$ & $* 32$ \\
\hline$V_{\mathrm{m}, \text { nitri }}$ & Maximum nitrification rate & 0.05 & day $^{-1}$ & 37 \\
\hline$K_{\mathrm{m}, \text { nitri }}$ & Half saturation constant for nitrification & 200 & $\mathrm{mmol} \mathrm{m}{ }^{-3}$ & 28 \\
\hline$r \mathrm{NO}_{\text {nitri }}$ & Fraction of NO production in nitrification & 0.002 & - & $38,39,40$ \\
\hline$r \mathrm{~N} 2 \mathrm{O}_{\text {nitri }}$ & $\begin{array}{l}\text { Fraction or } \mathrm{N}_{2} \mathrm{O} \text { production in nitrification } \\
\text { products }\end{array}$ & 0.0005 & - & $40,41,42,43$ \\
\hline$V_{\mathrm{m}, \mathrm{denitri}}$ & Maximum denitrification rate & 86.4 & $\mathrm{mmol} \mathrm{m}^{-3}$ day $^{-1}$ & 29 \\
\hline$k_{\mathrm{m}, \mathrm{denitri}}$ & Half saturation constant for denitrification & 1 & $\mathrm{mmol} \mathrm{m}^{-3}$ & 29 \\
\hline$r \mathrm{NO}_{\text {denitri }}$ & NO production rate constant in denitrification & 0.002 & $\mathrm{day}^{-1}$ & $40,42,44$ \\
\hline$r \mathrm{~N} 2 \mathrm{O}_{\text {denitri }}$ & $\mathrm{N}_{2} \mathrm{O}$ production rate constant in denitrification & 0.002 & day $^{-1}$ & 45 \\
\hline CSratiopeat & $\mathrm{C} / \mathrm{S}$ ratio in peat $\mathrm{SOM}$ & 318 & ${\mathrm{gC} \mathrm{gS}^{-1}}^{-1}$ & 14 \\
\hline SCratioplant & $\mathrm{S} / \mathrm{C}$ ratio in plants & 0.0022 & ${\mathrm{gS} \mathrm{gC}^{-1}}^{-1}$ & 46 \\
\hline
\end{tabular}

methods (Lafleur, 2003). The average difference between simulation and observation was $0.43 \mathrm{gC} \mathrm{m}^{-2} \mathrm{day}^{-1}$, which was small compared to the calculated error of GPP ( $\pm 0.42 \mathrm{gC} \mathrm{m}^{-2}$ day $\left.^{-1}\right)$ and to the potential correction factor of NEE (1.21 $\pm 0.12 \mathrm{gC} \mathrm{m}^{-2} \mathrm{day}^{-1}$ ) (Lafleur, 2003; Moore et al., 2006). Overall, ER was overestimated in dry summers, i.e. in 1999, 2001, 2002 and 2003, with a maximum discrepancy of $4.18 \mathrm{gC} \mathrm{m}^{-2} \mathrm{day}^{-1}$ in the driest and hottest summer in 2003 (Fig. 6b). The maximum underestimates of ER was $2.81 \mathrm{gC} \mathrm{m}^{-2} \mathrm{day}^{-1}$ in 22 July 2004 , during the period when the WT was underestimated most. The daily simulation has a degree of agreement of 0.92 and RMSE $0.64 \mathrm{gC} \mathrm{m}^{-2}$ day $^{-1}$ (Fig. 7a).

NEE was calculated from the simulated ER and GPP fluxes, therefore the absolute errors were enlarged in the simulation of NEE (Fig. 6c). The simulated peak uptake of NEE appeared annually during summer; during spring the bog took up carbon and in fall and winter lost it, as documented by measurements (Lafleur, 2003). The maximum simulated uptake occurred during the same period as in the observations, from June to early July, with values < $-2.5 \mathrm{gC} \mathrm{m}^{-2} \mathrm{day}^{-1}$ while the maximum loss appears mostly from September and October and was $>1 \mathrm{gC} \mathrm{m}^{-2} \mathrm{day}^{-1}$ (Roulet et al., 2007). Winter NEE was typically smaller than $1.5 \mathrm{gC} \mathrm{m}^{-2} \mathrm{day}^{-1}$, which falls in the lower range of the observations between $1.2-2.4 \mathrm{gC} \mathrm{m}^{-2} \mathrm{day}^{-1}$ (Lafleur, 2003). The dates when the bog turned from $C$ source to $\mathrm{C}$ sink in spring was 15 April ( \pm 8 days), and from $\mathrm{C}$ sink to $\mathrm{C}$ source on 30 September ( \pm 12 days). The turning point was less variable in spring than in fall, which agrees with observations, where the range was identified as 16 April \pm 5 days and 3 October \pm 17 days. The average error of daily NEE was $0.55 \mathrm{gC} \mathrm{m}^{-2} \mathrm{day}^{-1}$ during the $6 \mathrm{yr}$, with the maximum overestimation of $3.54 \mathrm{gC} \mathrm{m}^{-2} \mathrm{day}^{-1} \mathrm{oc}-$ curring on 4 August 2002, and the maximum underestimation of $3.41 \mathrm{gC} \mathrm{m}^{-2} \mathrm{day}^{-1}$ on 1 June 2002 , corresponding to the period when GPP was the most overestimated. The RMSE of the simulated NEE was $0.81 \mathrm{gC} \mathrm{m}^{-2} \mathrm{day}^{-1}$, and the degree of agreement was 0.78 (Fig. 7b). 
Table 4. Assumed and calibrated parameters.

\begin{tabular}{|c|c|c|c|c|c|c|c|}
\hline Name & Description & \multicolumn{3}{|c|}{ Value } & Unit & Source & Conf. \\
\hline \multicolumn{8}{|l|}{ Environment } \\
\hline$r \_$melting & Snow melt rate constant & \multicolumn{3}{|c|}{0.27} & $\mathrm{~m} \mathrm{~m}^{-1}$ & Calibrated & 2 \\
\hline snowmelt $_{\max }$ & Maximum snow melt rate & \multicolumn{3}{|c|}{0.007} & $\mathrm{~m} \mathrm{~m}^{-2}$ day $^{-1}$ & Assumed & 2 \\
\hline$r \_\mathrm{EPT}_{0}$ & Base evapotranspiration rate & \multicolumn{3}{|c|}{3.888} & - & Calibrated & 2 \\
\hline Plants & & Moss & Gram & Shrub & & & \\
\hline$f_{\mathrm{N}, \text { toxic }}$ & $\mathrm{N}$ effect on PSN when toxic & \multicolumn{3}{|c|}{0.01} & - & Assumed & 1 \\
\hline density $_{\text {finert, }} j$ & Fine roots density & - & 0.05 & 0.06 & $\mathrm{~g} \mathrm{~cm}^{-3}$ & ${ }^{28}$ Calibrated & 2 \\
\hline$r_{\text {cylinder }, j}$ & The radius of roots & - & 0.05 & 0.05 & $\mathrm{~cm}$ & ${ }^{28}$ Calibrated & 3 \\
\hline Li_frac $_{\mathrm{L}}$ & Fraction of labile litter quality & 0.1 & 0.3 & 0.2 & $\mathrm{~g} \mathrm{~g}^{-1}$ & ${ }^{48}$ Assumed & 2 \\
\hline$r_{\text {mort }}, \mathrm{sh}, j$ & Shoot mortality rate constant & 0.004 & 0.006 & 0.0015 & day $^{-1}$ & ${ }^{49}$ Calibrated & 3 \\
\hline$r_{\text {mort }, \mathrm{rt}, j}$ & Root mortality rate constant & - & 0.0019 & 0.0021 & day $^{-1}$ & ${ }^{49}$ Calibrated & 3 \\
\hline$r_{\text {deciduous }}$ & Deciduous rate constant & & day $^{-1}$ & ${ }^{49}$ Assumed & 2 \\
\hline$r_{-} \mathrm{exu}_{X, j}$ & Exudation rate constants & \multirow{2}{*}{\multicolumn{3}{|c|}{$0.003^{0.1}$}} & day $^{-1}$ & Assumed & 2 \\
\hline fracN $_{2}$ fix $_{\text {moss }}$ & $\mathrm{N}_{2}$ fixation fraction of mosses & & & & - & Calibrated & 1 \\
\hline \multicolumn{8}{|l|}{ SOM } \\
\hline$k \operatorname{Cpot}_{q}$ & $\begin{array}{l}\text { Inherent potential rate constant of } \\
\text { decomposition }\end{array}$ & \multicolumn{3}{|c|}{$k \operatorname{Cpot}_{R}=8 \times 10^{-6} k \mathrm{Cpot}_{\mathrm{L}}=25$} & day $^{-1}$ & Calibrated & 2 \\
\hline$k_{\text {fix }}$ & Base $\mathrm{N}_{2}$ fixation rate & 0.04 & \multicolumn{2}{|c|}{$\mathrm{gN} \mathrm{m}^{-2}$ day $^{-1}$} & \multicolumn{2}{|c|}{${ }^{50}$ Calibrated } & 2 \\
\hline \multicolumn{8}{|l|}{ Dissolved } \\
\hline$r$ red_SO ${ }_{4}^{2-}$ & $\mathrm{SO}_{4}^{2-}$ reduction rate constant & 0.1 & \multicolumn{2}{|c|}{$\mathrm{day}^{-1}$} & \multicolumn{2}{|c|}{${ }^{51}$ Calibrated $^{\$}$} & 2 \\
\hline $\mathrm{e}^{-}$fraction $_{s}$ & $\begin{array}{l}\text { fraction of nanowire pathway } \\
\text { contribute to } \mathrm{SO}_{4}^{2-} \text { reduction }\end{array}$ & 0.4 & \multicolumn{2}{|c|}{-} & \multicolumn{2}{|c|}{${ }^{52}$ Calibrated $^{\$}$} & 2 \\
\hline$r \_$red_HS ${ }_{i}$ & $\begin{array}{l}\text { Humic substances reduction rate } \\
\text { constant of layer I }\end{array}$ & 0.0001 & \multicolumn{2}{|c|}{ day $^{-1}$} & \multicolumn{2}{|c|}{${ }^{53}$ Calibrated $^{\$}$} & 2 \\
\hline$r_{-}$oxi_HS ${ }_{i}$ & $\begin{array}{l}\text { humic substances oxidation rate } \\
\text { constant }\end{array}$ & 0.05 & \multicolumn{2}{|c|}{ day $^{-1}$} & \multicolumn{2}{|c|}{ Assumed } & 1 \\
\hline specific_resistance & specific electron resistance of peat & 1 & \multicolumn{2}{|l|}{$\Omega \mathrm{m}$} & \multicolumn{2}{|c|}{ Assumed } & 1 \\
\hline
\end{tabular}

$M=\mathrm{C}, \mathrm{N} ; q=$ labile, recalcitrant; $Q=$ substrate, structural, $X=$ shoots, roots, leaves, stems, fine roots, coarse roots, $\mathrm{DM}_{\mathrm{g}}=\mathrm{CO}_{2}, \mathrm{CH}_{4}, \mathrm{O}_{2}, \mathrm{DM}_{\mathrm{s}}=\mathrm{NH}_{4}^{+}, \mathrm{NO}_{3}^{-}, \mathrm{DOM}$ $i=$ layer $i, j=$ Plant functional type $j$. * values were calculated for the reference or modified according to PFTs, ${ }^{* *}$ assumed to be the same as the $\mathrm{C} / \mathrm{N}$ ratio of the recycled litter, which is similar to the $\mathrm{C} / \mathrm{N}$ ratio of the smallest DON Glycine. ${ }^{\$}$ values were calibrated in a compounded way. Conf.: confidence of the calibrated or assumed parameter values. $1=$ low confidence, $2=$ intermediate confidence, $3=$ high confidence. ${ }^{1}$ Ivanov (1981), ${ }^{2}$ Frolking et al. (1996), ${ }^{3}$ Small (1972), ${ }^{4}$ Chapin III and Shaver (1989),

${ }^{5}$ Ellsworth et al. (2004), ${ }^{6}$ Cannell and Thornley (1998), ${ }^{7}$ Thornley (1998b), ${ }^{8}$ Thornley and Cannell (1992), ${ }^{9}$ Reynolds and Thornley (1982), ${ }^{10}$ Bragazza et al. (2005),

${ }^{11}$ Bragazza et al. (2012), ${ }^{12}$ Frolking et al. (2001), ${ }^{13}$ Bartsch and Moore (1985), ${ }^{14}$ Moore et al. (2005), ${ }^{15}$ Aerts et al. (1992), ${ }^{16}$ Heijmans et al. (2008), ${ }^{17}$ Aubin et al. (2000), ${ }^{18}$ Bond-Lamberty and Gower (2007), ${ }^{19}$ Güsewell (2005), ${ }^{20}$ Bubier et al. (2011), ${ }^{21}$ Kimball et al. (1997), ${ }^{22}$ Frolking et al. (2002), ${ }^{23}$ Aber and Federer (1992),

24 Ryan (1995), ${ }^{25}$ Ryan (1991), ${ }^{26}$ Thornley et al. (1995), ${ }^{27}$ Kronzucker et al. (1999), ${ }^{28}$ Kirk and Kronzucker (2005), ${ }^{29}$ Smart and Bloom (1991), ${ }^{30}$ Kielland (1994),

31 Manzoni et al. (2010), ${ }^{32}$ Clein and Schimel (1995), ${ }^{33}$ Conant et al. (2010), ${ }^{34}$ Walter et al. (2001), ${ }^{35}$ Nedwell and Watson (1995), ${ }^{36}$ Granhall and Selander (1973),

37 Reddy et al. (1984), ${ }^{38}$ Baumgärtner and Conrad (1992), ${ }^{39}$ Parsons et al. (1996), ${ }^{40}$ Xu and Prentice (2008), ${ }^{41}$ Breuer et al. (2002), ${ }^{42}$ Khalil et al. (2004), ${ }^{43}$ Ingwersen et al. (1999), ${ }^{44}$ Well et al. (2003), ${ }^{45}$ Murray and Knowles (2003), ${ }^{46}$ Novak and Wieder (1992).

Daily $\mathrm{CH}_{4}$ flux was simulated from 1999 to 2009 in order to compare with the observations from 2004 to 2008. Simulated daily $\mathrm{CH}_{4}$ flux covered a wide range from 0 to ca. $170 \mathrm{mg} \mathrm{m}^{-2} \mathrm{day}^{-1}$. Seasonal patterns were stronger in wet years, such as 2004 and 2006, when the fluxes reached a maximum in mid-summer. In the dry years (e.g. 2005, 2008), summer peaks were lacking and the maximum fluxes occurred during one day in late spring and early summer due to degassing when the water table quickly declined (Fig. 8a and b). The instantaneous degassing in the model was caused by the release of $\mathrm{CH}_{4}$ stored in each $5 \mathrm{~cm}$ layer that entered the unsaturated zone. Subsequently the $\mathrm{CH}_{4}$ fluxes fell to very small values due to limited production and increased methane oxidation during summer. The simulated $\mathrm{CH}_{4}$ flux agreed with the observed range from April to mid-May and was underestimated in summer (Fig. 8b).

\subsection{Dissolved $\mathrm{CH}_{4} \mathrm{CO}_{2}$ and $\mathrm{O}_{2}$ concentration}

The simulated daily concentration of dissolved $\mathrm{CH}_{4}$ and $\mathrm{CO}_{2}$ was plotted against depth for 2002 to evaluate the model output of belowground respiration (Fig. 9a and b). Both dissolved $\mathrm{CH}_{4}$ and $\mathrm{CO}_{2}$ accumulated with depth and showed clear seasonal dynamics with the seasonal WT fluctuation. Concentration of dissolved $\mathrm{CH}_{4}$ increased from $<0.1 \mathrm{mmol} \mathrm{L}^{-1}$ around the WT at $0.35 \mathrm{~cm}$ 

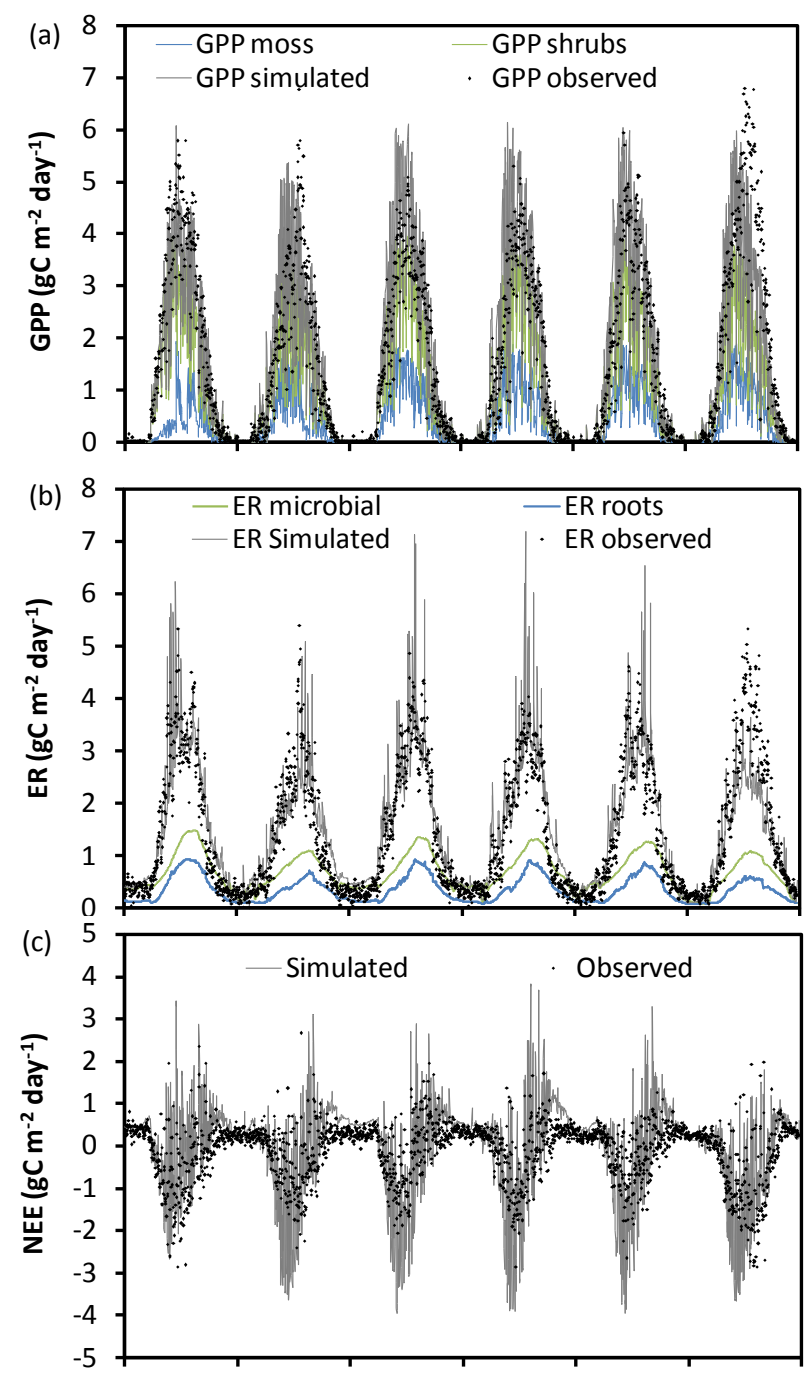

Jan-99 Jan-00 Jan-01 Jan-02 Jan-03 Jan-04 Jan-05

Fig. 6. Time series of daily observed average (symbols) and daily simulated (line) GPP and components (a), ER and its components (b), and NEE (c) for 1999-2004

to ca. $0.6 \mathrm{mmol} \mathrm{L}^{-1}$ at $80 \mathrm{~cm}$ depth in January and to ca. $0.5 \mathrm{mmol} \mathrm{L}^{-1}$ at $90 \mathrm{~cm}$ in October. Concentration of dissolved $\mathrm{CO}_{2}$ increased from $<0.1 \mathrm{mmol} \mathrm{L}^{-1}$ around the WT to ca. $3.5 \mathrm{mmol} \mathrm{L}^{-1}$ at $70 \mathrm{~cm}$ depth in January and to over $6 \mathrm{mmol} \mathrm{L}^{-1}$ in October. The maximum concentration in deep layers was ca. $7 \mathrm{mmol} \mathrm{L}^{-1}$ dissolved $\mathrm{CO}_{2}$ and $0.6 \mathrm{mmol} \mathrm{L}^{-1}$ dissolved $\mathrm{CH}_{4}$, respectively, close to the observed ranges (Beer and Blodau, 2007; Beer et al., 2008).

Figure $9 \mathrm{c}$ illustrates the profile of dissolved $\mathrm{O}_{2}$ concentration for the year 2002. The dissolved $\mathrm{O}_{2}$ was depleted rapidly below the WT, where concentration decreased from ca. $0.3 \mathrm{mmol} \mathrm{L}^{-1}$ at around the WT in January to ca. $0.1 \mathrm{mmol} \mathrm{L}^{-1}$ in October. Summer $\mathrm{O}_{2}$ concentration around the WT was lower than the rest of the year, due to the alteration of Henry's law constant of $\mathrm{O}_{2}$ by the increased summer

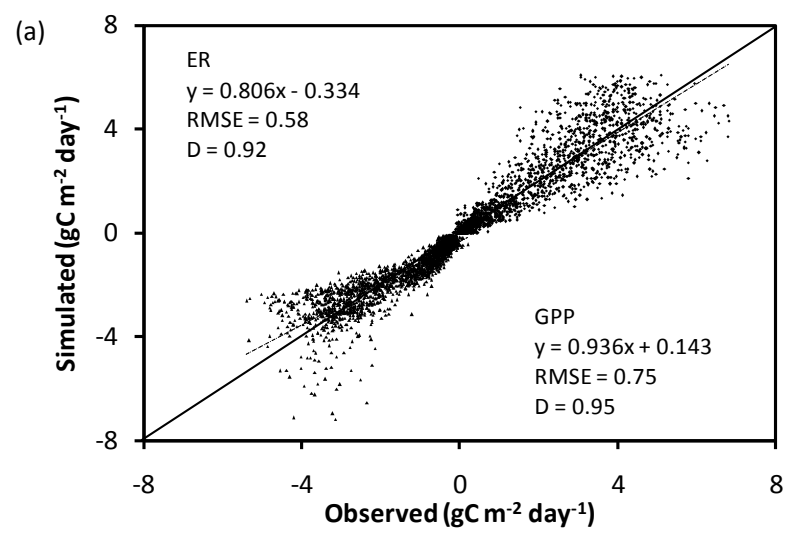

(b)

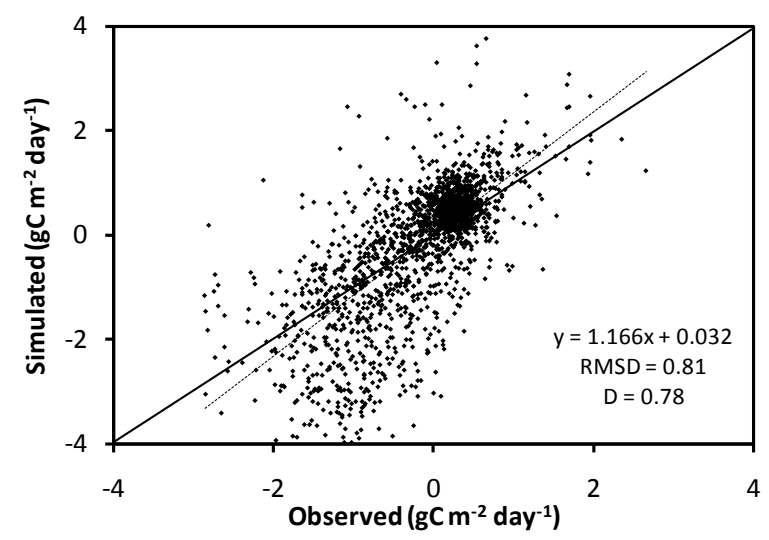

Fig. 7. The scatter plot of observed and simulated daily GPP and ER (a) and NEE (b) for 1999-2004, with the best fit relationship (dashed line) and the $1: 1$ line (solid black line).

temperature. Oxygen in soil was consumed by two processes in the model: organic $\mathrm{C}$ oxidation and methane oxidation. The annual consumption of $\mathrm{O}_{2}$ in methane oxidation was between $5 \%$ and $7 \%$ of the annual input of $\mathrm{O}_{2}$ from the atmosphere that diffused into the soil during the simulation period. Therefore methane oxidation was not an insignificant sink of oxygen, yet it was not highly important either.

\subsection{Annual $\mathrm{C}$ budget}

We calculated an annual C budget (Fig. 10a) based on the $6 \mathrm{yr}$ mean of annual simulated pool and flow rates (Table S1). Annual GPP ranged from $513 \mathrm{gC} \mathrm{m}^{-2} \mathrm{yr}^{-1}$ in the second wettest year 2000 to $609 \mathrm{gC} \mathrm{m}^{-2} \mathrm{yr}^{-1}$ in one of the dry years 2001 . Similar to the $550 \mathrm{gC} \mathrm{m}^{-2} \mathrm{yr}^{-1}$ of GPP in the conceptual C budget model for the Mer Bleue Bog (Moore et al., 2002), the average annual GPP was $555 \mathrm{gC} \mathrm{m}^{-2} \mathrm{yr}^{-1}$, of which $70 \%$ was contributed by shrubs and $26 \%$ by mosses. Average annual ER was $526 \mathrm{gC} \mathrm{m}^{-2} \mathrm{yr}^{-1}, 73 \%$ of which was emitted from the soil surface produced in HR of microorganisms and AR in roots. The difference of GPP and ER resulted in $286 \mathrm{gC} \mathrm{m}^{-2} \mathrm{yr}^{-1}$ of NPP of plants on average, whereas the 

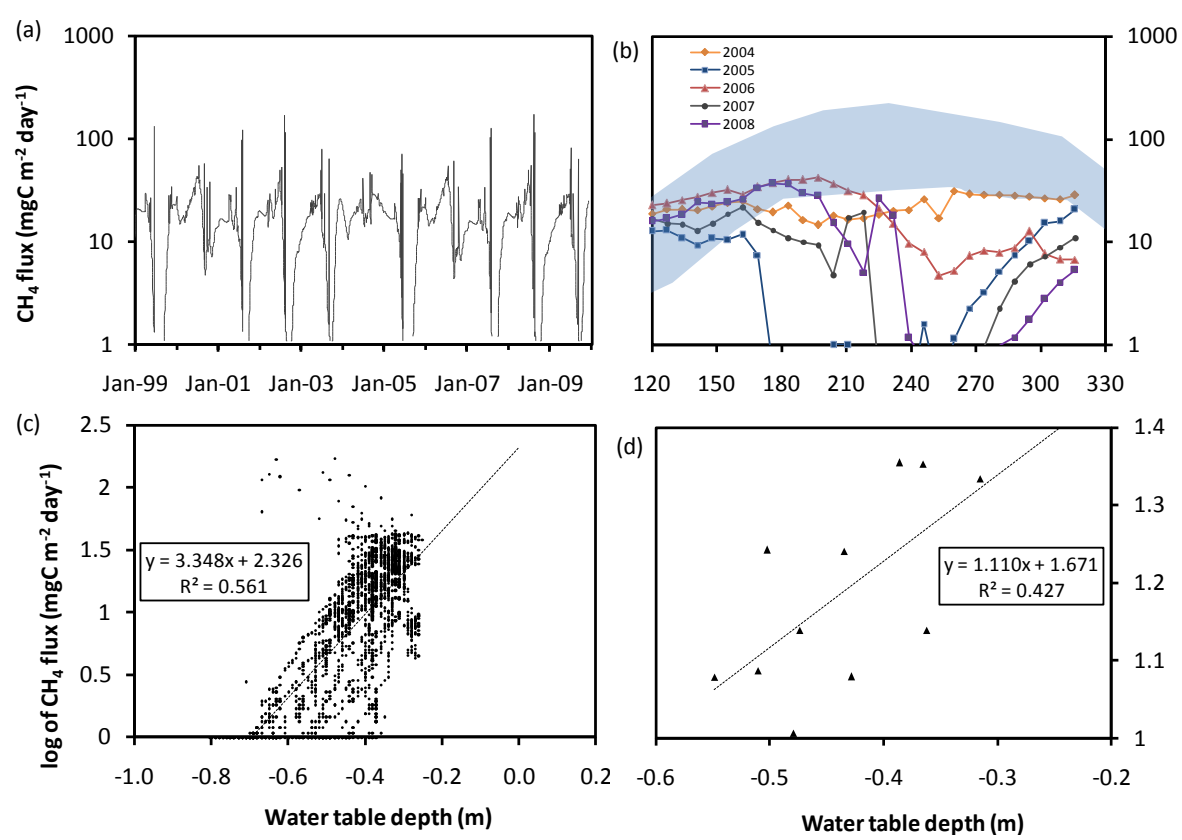

Fig. 8. Time series of (a) simulated daily CH4 flux $\left(\mathrm{mg} \mathrm{C} \mathrm{m}^{-2}\right.$ day $\left.^{-1}\right)$ from 1999 to 2009 , (b) simulated growing season (day of year 120 to 330) daily $\mathrm{CH} 4$ flux $\left(\mathrm{mg} \mathrm{C} \mathrm{m}^{-2} \mathrm{day}^{-1}\right.$ ) from 2004 to 2008 (blue area indicates the variation range as recorded for the Mer Bleue Bog averaged from 12 collars (Moore et al., 2011, Fig. 2), (c) relationship between the simulated growing season daily, and (d) annual average CH4 flux (mg C m${ }^{-2}$ day $\left.^{-1}\right)$ in $\log _{10}$ scale and the simulated daily water table depth (m) from 1999 to 2009.

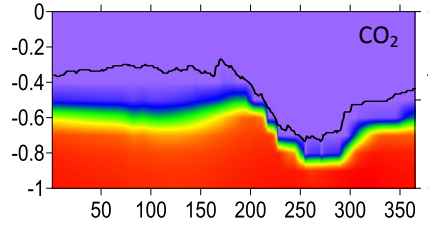

(a)

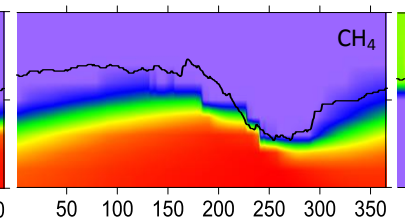

(b)

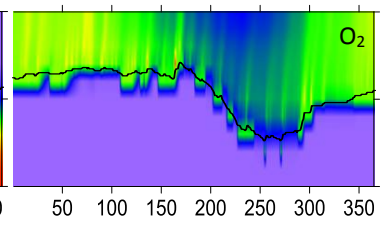

(c)

$\begin{array}{lllll}500 & 2000 & 3500 & 5000 \quad 6500\end{array}$

Fig. 9. Simulated profiles of dissolved $\mathrm{CO}_{2}(\mathbf{a})$, dissolved $\mathrm{CH}_{4}(\mathbf{b})$, and dissolved $\mathrm{O}_{2}(\mathbf{c})$ concentration (units: (umol $\left.\mathrm{L}^{-1}\right)$ in soil pore water in the year 2002. The black lines indicate water table depth (m).

average loss of $\mathrm{C}$ from the plants due to litter production and exudation was $296 \mathrm{C} \mathrm{m}^{-2} \mathrm{yr}^{-1}$. The difference of $10 \mathrm{gC}$ between NPP and the sum of litter production and exudation corresponded to the changes of biomass in the plants. Annual net ecosystem production (NEP) was $29 \mathrm{gC} \mathrm{m}^{-2} \mathrm{yr}^{-1}$, close to the low end of the estimated $40.2( \pm 40.5) \mathrm{gC} \mathrm{m}^{-2} \mathrm{yr}^{-1}$ (Roulet et al., 2007), which was based on 8 yr of observations from 1999 onwards. The model simulated an annual $\mathrm{CH}_{4}$ emission of $4 \mathrm{gC} \mathrm{m}^{-2} \mathrm{yr}^{-1}$ of which $83 \%$ stemmed from graminoid mediated emission. Emission of $\mathrm{CH}_{4}$ during the wet years of 2002 and 2004 were higher than in the dry years, as is the general trend observed in the Mer Bleue Bog and in other peatlands (Roulet et al., 2007). The simulated DOC export was $15 \mathrm{gC} \mathrm{m}^{-2} \mathrm{yr}^{-1}$, which was in agreement with the estimated $14.9( \pm 3.1) \mathrm{gC} \mathrm{m}^{-2} \mathrm{yr}^{-1}$ from $5 \mathrm{yr}$ of runoff and $3 \mathrm{yr}$ of DOC concentration measurements at the site.
The model suggested dissolved $\mathrm{CO}_{2}$ and $\mathrm{CH}_{4}$ loss in runoff was 0.29 and $0.01 \mathrm{gC} \mathrm{m}^{-2} \mathrm{yr}^{-1}$. These values were smaller than the estimated and variable $1.77 \mathrm{gC} \mathrm{m}^{-2} \mathrm{yr}^{-1}\left(\mathrm{CO}_{2}\right)$ and $0.05 \mathrm{gC} \mathrm{m}^{-2} \mathrm{yr}^{-1}\left(\mathrm{CH}_{4}\right)$ from the annual runoff in the Mer Bleue Bog drainage system (Billett and Moore, 2007). Finally, the net ecosystem carbon balance (NECB $=$ GPP-ER$\mathrm{CH}_{4}$-DOC-DIC) was obtained as $10( \pm 60) \mathrm{gC} \mathrm{m}^{-2} \mathrm{yr}^{-1}$. This value was smaller and more variable than field estimates of $21.5( \pm 39) \mathrm{gC} \mathrm{m}^{-2} \mathrm{yr}^{-1}$, although it fell within the possible range of -105 to $50 \mathrm{gC} \mathrm{m}^{-2} \mathrm{yr}^{-1}$ (Roulet et al., 2007).

\subsection{Annual N budget}

An annual $\mathrm{N}$ budget for the Mer Bleue Bog is illustrated based on the $6 \mathrm{yr}$ average of simulated values (Fig. 10b, Table S2). The wet annual $\mathrm{N}$ deposited from the atmosphere was $0.81 \mathrm{gN} \mathrm{m}^{-2} \mathrm{yr}^{-1}$ onto the 


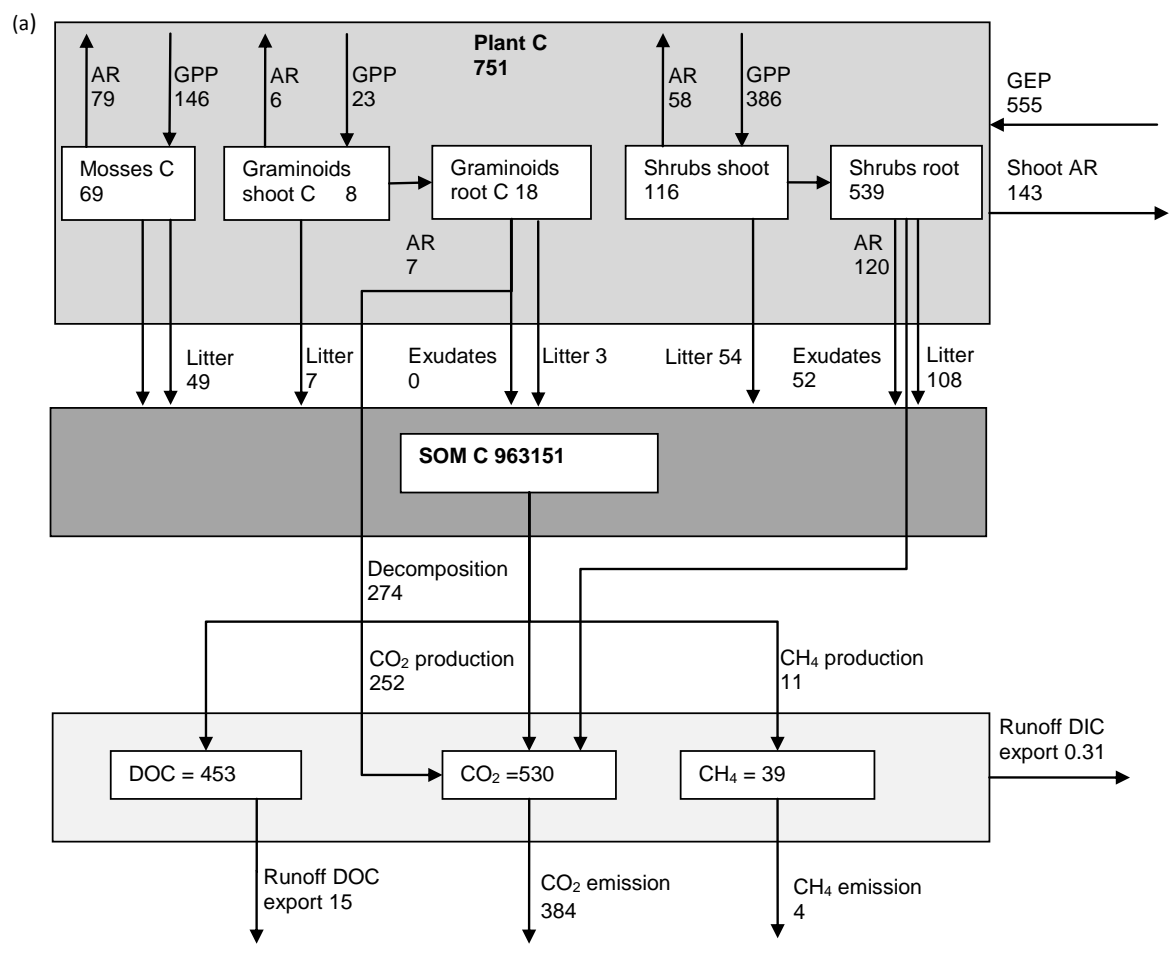

Fig. 10. Carbon budget (a) and nitrogen budget (b) for the Mer Bleue peatland based on simulated averages from 1999 to 2004 . Pools are in $\mathrm{g} \mathrm{m}^{-2}$ and fluxes are in $\mathrm{g} \mathrm{m}^{-2} \mathrm{yr}^{-1}$.

peatland. About $95 \%$ of the deposited $\mathrm{N}$ was absorbed by mosses right away. Nitrogen in the plants was associated with the plant biomass and composition, which both changed little over the $6 \mathrm{yr}$. Annually, mosses exported $0.82 \mathrm{gN} \mathrm{m}^{-2} \mathrm{yr}^{-1}$ in litter and $0.02 \mathrm{gN} \mathrm{m}^{-2} \mathrm{yr}^{-1}$ in exudates to the soil $\mathrm{N}$ pools. For vascular plants these fluxes were $2.97 \mathrm{gN} \mathrm{m}^{-2} \mathrm{yr}^{-1}$ and $0.02 \mathrm{gN} \mathrm{m}^{-2} \mathrm{yr}^{-1}$, respectively. $\mathrm{N}$ uptake was $1.68 \mathrm{gN} \mathrm{m}^{-2} \mathrm{yr}^{-1}$, mostly by shrubs as $\mathrm{NH}_{4}^{+}$, and only $0.3 \%$ of $\mathrm{N}$ uptake occurred in form of DON. $\mathrm{N}_{2}$ fixation was $0.96 \mathrm{gN} \mathrm{m}^{-2} \mathrm{yr}^{-1}$. Considering $\mathrm{N}$ uptake, $\mathrm{N}$ litterfall and $\mathrm{N}$ exudation, vegetation thus lost $0.38 \mathrm{gN} \mathrm{m}^{-2} \mathrm{yr}^{-1}$, which represents $2.5 \%$ per year over the simulation period. $\mathrm{The} \mathrm{NH}_{4}^{+}$pool was smaller than the annual production and uptake, implying a fast turnover of $\mathrm{NH}_{4}^{+}$in the soil. Other dissolved $\mathrm{N}$ pools $\left(\mathrm{NO}_{3}^{-}, \mathrm{N}_{2} \mathrm{O}\right.$ and $\left.\mathrm{NO}\right)$ were 3 to 8 magnitudes smaller than the $\mathrm{NH}_{4}^{+}$pool in the model, and $\mathrm{N}_{2} \mathrm{O}$ emission was negligible. Export of DON and DIN through water runoff was also very small and occurred at rates of $0.04 \mathrm{gN} \mathrm{m}^{-2} \mathrm{yr}^{-1}$ and $0.01 \mathrm{gN} \mathrm{m}^{-2} \mathrm{yr}^{-1}$, respectively. Overall, the $\mathrm{OM}$ pools received ca. $3.83 \mathrm{gN}$ from plant litter production and exudation and lost $1.91 \mathrm{gN}$ and $0.05 \mathrm{gN}$ by mineralization and runoff annually, which lead to an overall accumulation of $1.43 \mathrm{gN} \mathrm{m}^{-2} \mathrm{yr}^{-1}$ in the peat.

\subsection{Sensitivity analysis}

Sensitivity analysis is useful in quantifying the model responses to changes in environmental drivers and other parameters. We ran a series of simulations by adjusting key environmental variables, such as precipitation, air temperature and $\mathrm{N}$ deposition. Variations of these parameters were chosen to be within the possible range of variability in temperateboreal peatland ecosystems. We also adjusted parameters that are most uncertain and potentially influence $\mathrm{C}$ and $\mathrm{N}$ cycling in peatlands, such as $Q_{10}$ values and the rate constants of the decomposition of SOM. The sensitivity of key $\mathrm{C}$ and $\mathrm{N}$ fluxes, pools, and cycling rates, including GPP, AR, ER, HR, NEE, NECB, and $\mathrm{C}$ and $\mathrm{N}$ sequestration rates in the soil organic matter, were examined. The sensitivity was tested by imposing changes in air temperature between -1 and +5 with increments of $2{ }^{\circ} \mathrm{C}$, and changes in precipitation between $-30 \%$ and $+30 \%$ with increments of $15 \%$, which were in line with the scenario predictions of future climate (IPCC, 2007). The sensitivity to $\mathrm{N}$ deposition that covered the $\mathrm{N}$ deposition range in Europe was tested by imposing $\mathrm{N}$ input at $0.2,1.4,2,2.5$ and $3.2 \mathrm{gN} \mathrm{m}^{-2} \mathrm{yr}^{-1}$. The sensitivity to $Q_{10}$ of labile $\left(Q_{10, L}\right)$ and recalcitrant $\left(Q_{10, R}\right)$ soil organic matter were tested for $-40 \%$ and $+40 \%$ of the ambient value, respectively. The potential decomposition constant $k$ was tested with $-25 \%$ and $+25 \%$ of the ambient $k$ for labile $\left(k \operatorname{pot}_{L}\right)$ and recalcitrant $\left(k \operatorname{pot}_{L}\right)$ in the sensitivity tests. 
The simulations were conducted for six years and averaged to compare with the baseline simulations (Table 5).

The sensitivity analysis showed that heterotrophic respiration was the most sensitive process in $\mathrm{C}$ cycling with regard to air temperature. Temperature increase had a negative effect on the production of moss and a positive effect on the production of vascular plants, suggesting a favoring of vascular species in a warmer environment. The increase in AR in vascular plants with increasing $T$ was greater than the increase in production of vascular plants, which led to a negative effect on NPP. In the model, the $Q_{10}$ of respiration in plants was smaller than the $Q_{10}$ of photosynthesis, suggesting that other controls constrain primary production apart from temperature, such as $\mathrm{N}$ availability and soil moisture. The sensitivity of HR to temperature was greater than that of AR, resulting in preferential C loss from peat rather than from plant respiration with increasing temperature. The impact of temperature on ER was larger than on GPP and entailed a higher sensitivity of NEE to temperature as well. Although less $\mathrm{CH}_{4}$, DOC and DIC was exported when temperature was increased, NECB declined due to the greater change in NEE. Carbon sequestration was very sensitive to temperature in the model, and an increase of 1 degree in air temperature would turn the modeled peatland from a $\mathrm{C}$ sink into a $\mathrm{C}$ source. Nitrogen sequestration was also negatively affected by temperature, but to a lesser extent.

The processes GPP, AR, HR were less sensitive to precipitation than to temperature. This was not the case for the export of dissolved $\mathrm{C}$ and $\mathrm{CH}_{4}$ fluxes. Decreasing precipitation promoted primary production and autotrophic respiration in vascular plants, while inhibiting the production of mosses. Increasing precipitation more strongly raised NPP in shrubs than in mosses and had a negative effect on graminoids, suggesting vice versa that graminoids were more tolerant to dryness than shrubs and mosses. The increased NPP in shrubs resulted mostly from changing respiration rather than from gross primary production. Respiration in the model has a stronger dependency on soil moisture than GPP. In the analyses, HR was more sensitive to temperature and precipitation than AR and NPP, and it was more sensitive to temperature than to precipitation (Table 5). A decrease in precipitation by $30 \%$, corresponding to a decline of annual mean WT depth by $7 \mathrm{~cm}$, led to an HR increase of $11 \%$. In contrast DIC and DOC export declined by $36 \%$ and $66 \%$, respectively. The decrease of dissolved $\mathrm{C}$ exports was owed to the diminished runoff at lower WT position, despite more production of dissolved $\mathrm{C}$ with raised HR. As expected, $\mathrm{CH}_{4}$ flux was strongly positively related to precipitation. In contrast, elevated temperature decreased $\mathrm{CH}_{4}$ emission in the model through the lowered WT depth (Table 5).

Interestingly, the sequestration rate of $\mathrm{C}$ was similarly sensitive to precipitation and to temperature, while the $\mathrm{N}$ sequestration rate was much more sensitive to precipitation than to temperature. A decrease in precipitation by $30 \%$ caused a decrease in $\mathrm{C}$ sequestration rate by $19 \%$, which is compara- ble to the effect of an increase in temperature by 3 degrees. Meanwhile, the $\mathrm{N}$ sequestration rate decreased by $46 \%$ with the change in precipitation and by $10 \%$ with the change in temperature. This outcome resulted from the different mechanisms by which precipitation and temperature control the decomposition of soil organic matter. In the model, lowering the WT position via precipitation stimulated the decomposition rate of labile and recalcitrant soil equally. On the other hand, the temperature increases primarily the decomposition of recalcitrant $\mathrm{OM}$ due to a larger decomposition $Q_{10}$ of this pool. As recalcitrant soil is present mostly in the deeper layers and contains less $\mathrm{N}$, the temperature effect on $\mathrm{N}$ sequestration was weakened. Therefore, if recalcitrant SOM is more sensitive to temperature than labile SOM, as suggested by many (Davidson and Janssens, 2006; Conant et al., 2008; Craine et al., 2010; Karhu et al., 2010), the function of peatlands as $\mathrm{N}$ sinks will be more impaired than in predictions on models with equal $Q_{10}$ values for labile and recalcitrant SOM.

Nitrogen deposition levels affect mostly plant related C fluxes rather than soil derived fluxes. The sensitivity of GPP to $\mathrm{N}$ deposition was greater than to precipitation and temperature. Overall, the model suggests a strong promotion of graminoids over shrubs and mosses when the $\mathrm{N}$ deposition increases. The effect of N on both GPP and NPP was stronger in graminoids than in shrubs and mosses, due to the different $\mathrm{N}$ use strategy of the PFTs in the model (Table 5). Graminoids have advantages because faster turnover rates allow for instantaneous response to changes in $\mathrm{N}$ availability in the plant-soil system. In comparison, shrubs and mosses cycle $\mathrm{N}$ in a more conservative manner and need lower levels of $\mathrm{N}$ to keep photosynthesizing, hence these PFTs react more slowly to increases in N availability. The NPP of graminoids increased non-linearly with the $\mathrm{N}$ deposition level, by $70 \%$ with a $150 \%$ increase and $560 \%$ by a $300 \%$ increase in annual $\mathrm{N}$ deposition (Table S3). This finding implies other constraints on the NPP of graminoids at low N deposition levels. The main constraint was very likely $\mathrm{N}$ filtration by mosses, which was alleviated when mosses became $\mathrm{N}$ saturated at higher $\mathrm{N}$ deposition levels.

The NPP of shrubs was highest at moderate $\mathrm{N}$ deposition level of $2.6 \mathrm{gN} \mathrm{m}^{-2} \mathrm{yr}^{-1}$, probably due to increased shading effects from the faster expansion of graminoids with more $\mathrm{N}$ deposition (Table S3). The NPP of mosses was negatively affected by $\mathrm{N}$ deposition, and only a slight promotion of GPP occurred when $\mathrm{N}$ deposition was slightly raised. Very different from the effects of the climatic drivers, $\mathrm{N}$ deposition levels had hardly an effect on HR. Other $\mathrm{C}$ effluxes, including dissolved $\mathrm{C}$ export, $\mathrm{CH}_{4}$ flux and $\mathrm{AR}$ were also less sensitive to $\mathrm{N}$ deposition than to temperature and precipitation. As GPP and ER were both positively affected by increasing $\mathrm{N}$, the NEE, NECB and C sequestration rate of peat were not very sensitive to $\mathrm{N}$ deposition. In contrast, $\mathrm{N}$ sequestration in soil organic matter showed a strong positive relation to $\mathrm{N}$ deposition level. 
Table 5. Results of sensitivity analyses. The values shown are the average relative changes in model output per change of parameter (Jørgensen and Bendoricchio, 2001). Annual C fluxes (unit: $\mathrm{gC} \mathrm{m}^{-2} \mathrm{yr}^{-1}$ ) averaged over 6 yr from 1999 to 2004 were compared per change of air temperature (unit: ${ }^{\circ} \mathrm{C}$ ), precipitation (unit: $\left.\mathrm{m} \mathrm{day}^{-1}\right), \mathrm{N}$ deposition level $\left(\mathrm{gN} \mathrm{m}^{-2} \mathrm{yr}^{-1}\right), Q_{10}$ (no unit) and kpot (potential decomposition constant, unit: day ${ }^{-1}$ ) of the labile and recalcitrant Peat. $(+)$ indicates a positive relation between the change in the parameter and the change $\mathrm{C}$ and $\mathrm{N}$ pools or fluxes. (-) indicates an inverse relation between the change in parameter and the change in $\mathrm{C}$ and $\mathrm{N}$ pools or fluxes.

\begin{tabular}{lrrrrrrr}
\hline Parameters & Air Temperature & Precipitation & $\mathrm{N}$ deposition & $Q_{10, R}$ & $Q_{10, L}$ & $K_{\text {pot } R}$ & $K_{\text {pot } L}$ \\
\hline GPP & +0.08 & -0.04 & +0.12 & +0.02 & 0.00 & +0.06 & +0.01 \\
PSN moss & -0.05 & +0.01 & +0.01 & -0.03 & 0.00 & -0.09 & -0.02 \\
PSN gram & +0.03 & -0.16 & +0.69 & +0.08 & +0.01 & +0.26 & +0.05 \\
PSN shrub & +0.13 & -0.05 & +0.13 & +0.04 & +0.01 & +0.11 & +0.02 \\
AR & +0.25 & -0.17 & +0.19 & +0.03 & 0.00 & +0.08 & +0.02 \\
AR moss & +0.08 & 0.00 & +0.15 & 0.00 & 0.00 & 0.00 & 0.00 \\
AR gram & +0.09 & -0.12 & +0.53 & +0.06 & +0.01 & +0.20 & +0.04 \\
AR shrub & +0.34 & -0.25 & +0.19 & +0.04 & +0.01 & +0.11 & +0.02 \\
NPP moss & -0.22 & +0.03 & -0.18 & -0.06 & -0.19 & -0.20 & -0.04 \\
NPP gram & -0.02 & -0.19 & +0.85 & +0.10 & +0.31 & +0.32 & +0.06 \\
NPP shrub & -0.01 & +0.85 & +0.08 & +0.03 & +0.10 & +0.11 & +0.02 \\
HR & +0.39 & -0.30 & +0.01 & +0.35 & +0.13 & +0.83 & +0.26 \\
ER & +0.33 & -0.25 & +0.10 & +0.20 & +0.07 & +0.47 & +0.14 \\
CH $H_{4}$ flux & -0.30 & +0.75 & +0.07 & +0.32 & 0.00 & +1.03 & +0.05 \\
DOC export & -0.08 & +0.80 & -0.04 & +0.21 & +0.10 & +0.55 & +0.20 \\
NEE & -4.43 & +3.72 & +0.39 & -3.24 & -1.16 & -7.22 & -2.24 \\
DIC export & -0.73 & +2.95 & -0.19 & +0.10 & -0.02 & +0.49 & 0.00 \\
NECB & -15.47 & +11.28 & +1.05 & -12.18 & -4.35 & -27.47 & -0.98 \\
C sequestration rate & -5.09 & +6.13 & +0.02 & -7.02 & -2.54 & -16.57 & -4.93 \\
N sequestration rate & -0.15 & +1.17 & +0.77 & -0.80 & -0.26 & -1.78 & -0.44 \\
\hline
\end{tabular}

Processes in the model were generally more sensitive to changes in parameters related to the recalcitrant $\mathrm{OM}$ fractions (Table 5). Plant-derived C fluxes were little sensitive to $Q_{10, L}, Q_{10, R}$ and $k \operatorname{pot}_{L}$, but moderately sensitive to $k \operatorname{pot}_{L}$. The effects of $k \operatorname{pot}_{L}$ on GPP occur through changes in N availability in the peat, which varies according to the decomposition rate of the recalcitrant soil. The processes HR, NEE, NECB and the sequestration rates of $\mathrm{C}$ and $\mathrm{N}$ in soil showed greater and significant sensitivity to $k \operatorname{pot}_{L}$ and $Q_{10, \mathrm{R}}$ than to $k \operatorname{pot}_{L}$ and $Q_{10, L}$, showing the importance of the recalcitrant SOM pool for HR. In the short term, the process most sensitive to all varied factors other than $k \operatorname{pot}_{L}$ was the net ecosystem carbon balance (NECB).

\subsection{Nitrogen saturation}

Increased $\mathrm{N}$ deposition has been observed to change vegetation composition and the $\mathrm{C}$ and $\mathrm{N}$ retention in mosses, vascular species, and peat (Lamers et al., 2001; Xing et al., 2010; Bragazza et al., 2012). The model was in part designed for quantifying changes in PFTs and for identifying the threshold of $\mathrm{N}$ deposition level where $\mathrm{N}$ saturation occurs in mosses. To study the plausibility of the model behavior we carried out a $40 \mathrm{yr}$ simulation with raised atmospheric $\mathrm{N}$ input (Fig. 11). We adjusted the $\mathrm{N}$ deposition to $1.5 \mathrm{gN} \mathrm{m}^{-2} \mathrm{yr}^{-1}$, which is the intermediate $\mathrm{N}$ deposition in the sensitivity analysis and has been suggested to be the critical load of $\mathrm{N}$ for mosses
(Vitt et al., 2003). The $\mathrm{C}$ and $\mathrm{N}$ pools in PFTs showed a delay in responses to elevated $\mathrm{N}$ deposition (Fig. 11a and b). The fraction of deposited $\mathrm{N}$ absorbed by mosses remained steady for the first $12 \mathrm{yr}$ until the $\mathrm{N}$ content reached $0.02 \mathrm{gN} \mathrm{g}^{-1}$ biomass (Fig. 11d). Above this content level, the fraction of $\mathrm{N}$ retained by mosses declined rapidly and excess $\mathrm{N}$ entered the pore water. As a result, only then did the fraction of deposited $\mathrm{N}$ retained in vascular plants and peat increase and peaked after ca. $20 \mathrm{yr}$ (Fig. 11c).

Nitrogen mineralization rates increased immediately after raising $\mathrm{N}$ deposition, because of the elevated litter production in plants and exudation of mosses (Fig. 11f). Output of $\mathrm{N}$ from the model ecosystem was about $5 \%$ of the total $\mathrm{N}$ input from deposition and $\mathrm{N}_{2}$ fixation, and was continuously increasing after moss filtration of $\mathrm{N}$ became less effective (Fig. 11f).

One of the important findings of this exercise was that total biomass and total NPP remained comparatively stable, while the plant composition of biomass and NPP changed greatly (Fig. 11a and e).The moss cover was completely diminished, while graminoids started to expand with higher $\mathrm{N}$ availability in the soil water and eventually became the dominant PFT. An increase in the labile fraction of SOM was a further consequence because invading vascular plants produce more labile litter in the model. Owing to both the increased litter inputs from the vegetation and raised litter decomposability, 

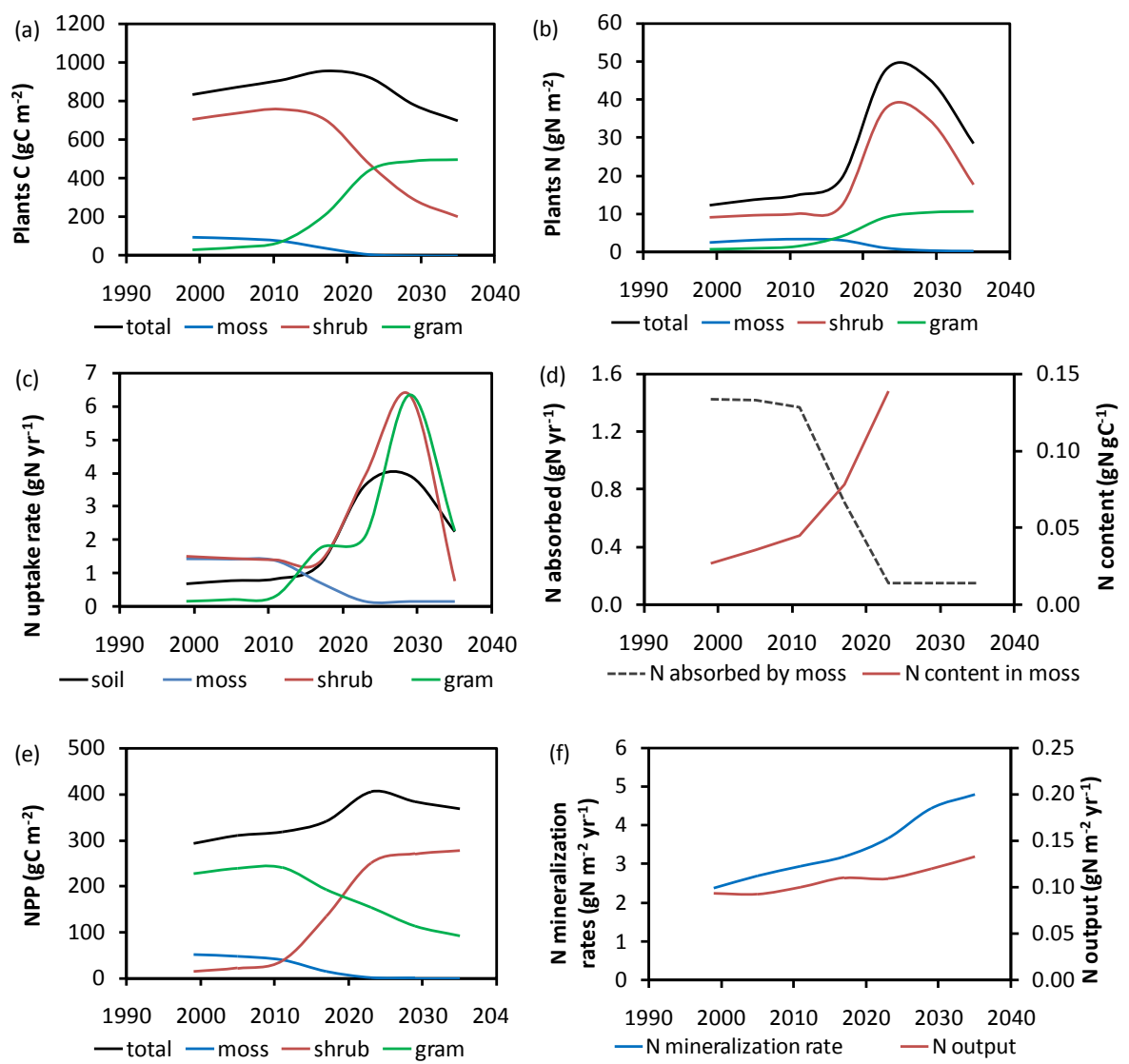

Fig. 11. Simulated C pools (a), N pools (b) and NPP (e) in plants and PFTs, N uptake rate by in plants and sequestration rate in peat (c), $\mathrm{N}$ absorbed by moss and $\mathrm{N}$ content in mosses (d), $\mathrm{N}$ mineralization rate and $\mathrm{N}$ output from peat (f) at annual wet $\mathrm{N}$ deposition of $1.5 \mathrm{~g} \mathrm{~N} \mathrm{~m}^{-2} \mathrm{yr}^{-1}$ from 1999 to 2039 .

the sequestration rate of $\mathrm{C}$ in soil first accelerated but then slowed after the NPP had peaked (Fig. 11e).

\section{Discussion}

\subsection{Carbon fluxes and environmental controls}

The fluxes GPP, ER and NEE are the essential components in $\mathrm{C}$ cycling that express the ability of peatland ecosystems in assimilating and dissimilating $\mathrm{C}$ and exchange the element with the atmosphere. Overall, the model simulations showed good agreement in daily $\mathrm{C}$ fluxes, belowground $\mathrm{C}$ concentration and annual $\mathrm{C}$ and $\mathrm{N}$ budgets with empirical data. However, a bias occurred towards underestimating simulated GPP (i.e. slope $=0.936$ ), underestimating simulated ER (i.e. slope $=0.806$ ) and overestimating simulated NEE (i.e. slope $=1.166$ ). These biases are within the bias range of the other models that primarily focus on C cycling (e.g. MWM, PCARS). The model performance differed in that in MWM and PCARS the simulated ER was overestimated, while it was underestimated in the PEATBOG model.
The $6 \mathrm{yr}$ averaged annual GPP demonstrates the ability of the model in simulating overall productivity, as only a small deviation of $5 \mathrm{gC} \mathrm{m}^{-2}$ was recorded against an empirically determined large average GPP of $550 \mathrm{gC} \mathrm{m}^{-2}$ at the site (Moore et al., 2002). Also the trends in interannual variation of GPP with precipitation and temperature were largely met. Noteworthy is for example the decline in GPP in the extremely dry year 1999, when dryness had a large impact on the GPP of mosses, and the high GPP in the warm and wet year of 2001 (Figs. 5b and 6a). While overall model performance was good some deviation from empirical measurements were illustrated by the analysis as well. Annual GPP was overestimated by 32 to $85 \mathrm{gC} \mathrm{m}^{-2} \mathrm{yr}^{-1}$ from year 2000 to 2003 and underestimated by 70 to $123 \mathrm{gC} \mathrm{m}^{-2} \mathrm{yr}^{-1}$ for the remaining years by the model simulations (Table 6). The discrepancy of annual GPP simulations ranged from $7 \%$ to $18 \%$ and was not significant ( $P=0.737, n=2192)$. The simulated GPP fraction of shrubs was $70 \%$, ranging from $66 \%$ in the simulated wettest year of 2004 and $78 \%$ in the driest year 1999. This range was similar to the model output of MWM that ranged from $61 \%$ to $67 \%$ (St-Hilaire et al., 2010) and smaller than the shrub related fraction of GPP 
of $80 \%$ to $85 \%$ reported from the PCARS model (Frolking et al., 2002). Inter-annual variation of GPP for PFTs was corroborated by observation (Bubier et al., 2003): GPP of mosses increased from dry to wet years from $4 \%$ to $48 \%$, whereas GPP of shrubs was at its lowest levels in the wet years. In comparison to other models (St-Hilaire et al., 2010; Dimitrov et al., 2011), the inhibition of GPP of shrubs due to dryness is less effective in our model.

On the daily timescale some weakness of the model in responding to weather conditions became visible. In general, the simulated GPP was deficient in capturing short-term extreme fluxes. All large underestimates $\left(>2 \mathrm{gC} \mathrm{m}^{-2} \mathrm{day}^{-1}\right)$ in the GPP simulation occurred during mid-summer in the two wet years 2000 and 2005, when GPP in the peatland was larger than $5 \mathrm{gC} \mathrm{m}^{-2} \mathrm{day}^{-1}$, except for two days in late summer. The likely reason for the lack of adequate model performance during this time are the maximum photosynthesis rates that are set for each PFT and the impossibility to cover the daily observed extreme values that were averaged from half hour records in the measurements. This disadvantage also occurred in other models with maximum rate settings that are based on the Farquhar photosynthesis model (e.g. MWM). We also noticed that most of the underestimates that occurred in 2004 were associated with frequent heavy precipitation that raised production instantly. In the model, the production of mosses is the only PFT that reacts to precipitation directly through the water content in the capitulum of mosses. The indirect controls of precipitation on the production of vascular plants via WT depth is likely the reason of the underestimated promotion of photosynthesis by frequent precipitation, especially when other controlling factors (i.e. temperature, light) are within the optimal range. For example, a peak of measured daily GPP was observed during late July 2004, during one of the periods that underestimated GPP. At this time precipitation was continuous at $>10 \mathrm{~mm} \mathrm{day}^{-1}$ and temperature was within an optimal range $\left(20 \pm 3^{\circ} \mathrm{C}\right)$.

The overestimation of GPP mainly occurred during late May to early June in the dry years (2001 to 2003) when PAR was comparably strong ( $>600 \mathrm{umol} \mathrm{m}^{-2} \mathrm{~s}^{-1}$ ). During those days, the model predicted GPP of mosses and shrubs to reach a level above $1.2 \mathrm{gC} \mathrm{m}^{-2} \mathrm{day}^{-1}$ and $2 \mathrm{gC} \mathrm{m}^{-2} \mathrm{day}^{-1}$, respectively. Daily measured GPP in the Mer Bleue Bog was found to be significantly albeit weakly related to PAR $\left(P<0.001 ; r^{2}=0.19\right)$ (Moore et al., 2006). In the model, this relationship is significantly stronger $\left(r^{2}=0.75\right)$, due to neglecting the non-linearity of leaf response to light in the integration of canopy photosynthesis using just Beer's law. The non-linearity of leaf response to light is related to the diurnal effects on the canopy. It includes for example optimized nitrogen distribution in plant canopies, different responses to light in sun and shade leaves, and variation of stomatal conductance with light levels (Thornley, 2002; Hikosaka, 2003). Late May to early June was also the period when new biomass is built up, which affects the distribution of
$\mathrm{N}$ within the plants. For example, both total $\mathrm{N}$ content and chlorophyll-a concentration in evergreen shrub foliage were low in spring and increased steadily to early June, as shown in measurements (Moore et al., 2006). The model lacks separated $\mathrm{N}$ pools in foliage and stems, where $\mathrm{N}$ content could show great variations due to phenology, which might be the reason of the overestimation of GPP in late spring.

The fluxes ER and NEE represent the gross and net release of $\mathrm{CO}_{2}$ from peatlands, and largely determine the $\mathrm{C}$ balance of the ecosystem. The model reproduced the composition of ER, where HR contributed half of the total ER, while the other half was almost equally shared by AR in shoots and AR in roots, as approximately suggested by field measurements (Moore et al., 2002). However, the standard deviation of the simulated annual ER and NEE was larger than that in field estimates (50\% and $40 \%$ ), suggesting a larger inter-annual variation than measured in the field. The modeled annual ER ranged from $430 \mathrm{gC} \mathrm{m}^{-2} \mathrm{yr}^{-1}$ to $573 \mathrm{gC} \mathrm{m}^{-2} \mathrm{yr}^{-1}$, with an average of $526 \mathrm{gC} \mathrm{m}^{-2} \mathrm{yr}^{-1}$ (Table $\mathrm{S} 1$ ), which is close to the flux quantified as $461 \mathrm{gC} \mathrm{m}^{-2} \mathrm{yr}^{-1}$ (Lafleur et al., 2001). The annual discrepancy ranged from $3 \%$ to $17 \%$, with an exception of $25 \%$ in 2004, when the highest summer WT occurred (Table 6). The underestimation of ER was probably caused by the simulated WT depth (Fig. 5b) that was 5 to $10 \mathrm{~cm}$ higher than measured in summer when both autotrophic respiration (AR) and heterotrophic respiration (HR) were potentially high. The modeled NEE showed similar interannual patterns to ER with the annual error being between $35 \mathrm{gC} \mathrm{m}^{-2} \mathrm{yr}^{-1}$ to $18 \mathrm{gC} \mathrm{m}^{-2} \mathrm{yr}^{-1}$. The largest deviation of simulated NEE from measurements was $106 \mathrm{gC} \mathrm{m}^{-2} \mathrm{yr}^{-1}$ in 1999, when GPP was under- and ER overestimated.

The ER was also overestimated from 1999 and 2003 (Fig. 6b). To identify the reasons, we calculated the deviation between measured and model daily ER, and regressed it against the deviation of measured and modeled daily temperature. According to this approach the overestimate of ER from 1999 to 2003 could be explained by an overestimate of soil temperature $\left(r^{2}=0.26\right)$, especially during summer $\left(r^{2}=0.68\right)$. Both ER and HR were strongly correlated to soil temperature at $0.2 \mathrm{~cm}$ depth with $r^{2}$ of 0.88 and 0.83 , respectively $(n=2193)$. The strong temperature dependence of ER and HR was associated with the $Q_{10}$ values used in the model for the temperature effects on HR rates. Different from other models, where $Q_{10}$ values were set to 2 for microbial respiration in soil, $Q_{10}$ value for the decomposition of recalcitrant $\mathrm{OM}$ (3.3) was set to be larger than for labile OM (2.3). These $Q_{10}$ values were in line with some of the most recent results (Davidson and Janssens, 2006; Conant et al., 2008, 2010; Karhu et al., 2010), their application implies a stronger increase in $\mathrm{C}$ loss from peatlands in a warmer climate. It has to be noted that some have assumed the value of $Q_{10}$ for labile OM to be larger (Liski et al., 1999; Giardina and Ryan, 2000; Thornley and Cannell, 2001) than or similar to (Fang et al., 2005) that of recalcitrant OM; in this case climate change effect on NEE may not be as extraordinary as 
Table 6. Observed (Obs.), simulated (Sim.), and the difference (D) between observed and simulated annual GPP, ER and NEE (units: $\mathrm{gC} \mathrm{m}^{-2} \mathrm{yr}^{-1}$ ) and summer average water table depth (unit: $\mathrm{m}$ ) from 1 May to 30 October for $6 \mathrm{yr}$ for the Mer Bleue Peatland.

\begin{tabular}{rrrrrrrrrrrrr}
\hline \multicolumn{3}{c}{ GPP } & \multicolumn{3}{c}{ ER } & \multicolumn{3}{c}{ NEE } & \multicolumn{3}{c}{ WTD } \\
\hline Year & Obs. & Sim. & D & Obs. & Sim. & D & Obs. & Sim. & D & Obs. & Sim. & D \\
1999 & 593 & 523 & -70 & 537 & 573 & 36 & -56 & 42 & 99 & -0.49 & -0.61 & -0.12 \\
2000 & 481 & 513 & 32 & 456 & 470 & 14 & -25 & -47 & -22 & -0.34 & -0.33 & 0.01 \\
2001 & 524 & 609 & 85 & 532 & 581 & 49 & 8 & -33 & -41 & -0.48 & -0.52 & -0.04 \\
2002 & 495 & 560 & 65 & 487 & 570 & 83 & -9 & 4 & 13 & -0.51 & -0.50 & 0.01 \\
2003 & 513 & 562 & 49 & 498 & 533 & 35 & -15 & -32 & -17 & -0.46 & -0.49 & -0.03 \\
2004 & 686 & 563 & -123 & 574 & 431 & -143 & -112 & -134 & -22 & -0.40 & -0.37 & 0.03 \\
\hline
\end{tabular}

has been anticipated otherwise. The sensitivity analysis on $Q_{10}$ and potential decomposition rates for our model highlighted the importance of the recalcitrant OM over the labile $\mathrm{OM}$ for the $\mathrm{C}$ cycling in peatlands (Table 5).

The $Q_{10}$ values derived from the first order exponential equations of the simulated ER and HR were only 2.56 and 1.97, respectively. The $Q_{10}$ for $\mathrm{HR}$ was thus smaller than either of the $Q_{10}$ for labile or recalcitrant OM, revealing the importance of other factors that confound the temperature response of HR. The WT depth was the most important factor affecting the calculated $Q_{10}$ values with $r^{2}$ of 0.75 between the average summer WT depth and the calculated $Q_{10}$ values. In summer, the low soil moisture in the most upper peat layers counteracted the potential enhancement of respiration by temperature. Nevertheless, the sensitivity analysis suggested a lesser effect of WT depth than of soil temperature on $\mathrm{CO}_{2}$ fluxes (Table 5). The daily simulated WT depth moderately correlated with ER $\left(r^{2}=0.51, n=2192\right)$, with $r^{2}$ ranging from 0.19 in the wet year 2000 to 0.79 in the dry years. Although stronger than reported from empirical studies, this relationship was in a broad agreement with field results as far as the trend of tighter correlation in dry years goes (Bubier, 2003; Lafleur et al., 2005b; Blodau et al., 2007).

The $\mathrm{CH}_{4}$ fluxes modeled with our novel thermodynamickinetic approach were in a reasonable range but smaller and their seasonal pattern less pronounced than obtained with chamber measurements at the Mer Bleue Bog (Moore et al., 2011). We attribute this difference to the variability of in situ plant cover and a higher mean water table position of the 12 gas flux collars of the field study. The collars were not only located in hummocks and lawns but also in hollows. The observed average WT depth was $-35( \pm 8.4 \mathrm{~cm})$ for the 12 collars from 2004 to 2008, whereas the simulated average WT depth was $-41 \mathrm{~cm}$ for the same time period. Due to the generally observed exponential increase in emissions with raising water table (Moore et al., 1998), even a small number of sampled wet locations may lead to much larger emissions than simulated in the model, which represents a hummock situation. The large discrepancy after summer was very likely due to the effects of vegetation transport on $\mathrm{CH}_{4}$ flux, which was the most important control on the $\mathrm{CH}_{4}$ flux from September to November over $5 \mathrm{yr}$ (Moore et al., 2011). In the model, graminoid cover was less than $1 \%$ during the simulation period, whereas the graminoid cover ranged from 0 to $100 \%$ in the 12 collars. Comparing model output to one of the gas flux collars similar in water table and graminoid cover (collar 8, Table 2, Moore et al., 2011) with daily $\mathrm{CH}_{4}$ flux between 10 to $100 \mathrm{mg} \mathrm{m}^{-2} \mathrm{day}^{-1}$, a closer model fit was obtained. In this collar, as in our model, $\mathrm{CH}_{4}$ emission increased less in summer than in the more grass-rich collars (Moore et al., 2011).

The growing season $\log _{10}$ values of both daily and annual $\mathrm{CH}_{4}$ fluxes showed moderately strong relations with WT depth $\left(r^{2}=0.56, n=2119\right.$ and $\left.r^{2}=0.45, n=11\right)$ (Fig. 8c and $\mathrm{d}$ ). The outliners were the degassing events, which occurred when water table was crossing the boundaries of peat layers in the model. The WT depth during the growing season showed differing effects on $\mathrm{CH}_{4}$ fluxes in dry years and wet years, as was also found in the field (Moore et al., 2011). According to the model results, the lowest dependence of $\mathrm{CH}_{4}$ flux on the WT depth occurred in the dry years and the highest dependence in the wetter years. This finding is in conflict with relations obtained from field data, where $\mathrm{CH}_{4}$ emissions were less related to summer WT depth in wetter years. The annual variation in $\mathrm{CH}_{4}$ production is less pronounced than in $\mathrm{CH}_{4}$ fluxes (Table $\mathrm{S} 1$ ); this implies that changes in the transport mode of $\mathrm{CH}_{4}$ might offset the well-known WT control on methanogenesis. For example, the root biomass of graminoids, that provide conduits for $\mathrm{CH}_{4}$ transport, was negatively correlated with WT depth and $\mathrm{CH}_{4}$ fluxes. In the dry years, graminoid root biomass increased with declining WT in the model, due to more reallocation of newly produced biomass to roots for accessing soil water. This adaptation also increased the transport of $\mathrm{CH}_{4}$ from the deeper peat. Overall, the model was able to simulate the variation of $\mathrm{CH}_{4}$ fluxes with the change of environmental controls, and revealed some interesting dynamic interactions with ecosystem structure that warrant further analysis in the future. 


\section{$5.2 \quad \mathrm{~N}$ budget and $\mathrm{N}$ saturation}

The simulated $\mathrm{N}$ budget identified the Mer Bleue Bog as a currently N-limited ecosystem and sink for the element. The immobilization of deposited $\mathrm{N}$ by mosses was at a maximum level of $95 \%$, including both the retention of $\mathrm{N}$ in the capitulum of Sphagnum mosses and indirect retention via their stems. In the simulation of $\mathrm{N}$ saturation, the model was able to track the effect of $\mathrm{N}$ deposition in different compartments of the ecosystem. The $\mathrm{N}$ content in mosses peaked at $0.02 \mathrm{gN} \mathrm{g}^{-1}$ biomass, similar to the field observations of 0.015 to $0.024 \mathrm{~g} \mathrm{~g} \mathrm{~g}^{-1}$ biomass (Heijmans et al., 2001; Granath et al., 2009; Xing et al., 2010). The simulated increase in soil organic matter mineralization was in agreement with most fertilization experiments (Bragazza et al., 2006; Breeuwer et al., 2008). It was closely related to a change in peat chemistry, such as reflected in the size of the labile $\mathrm{OM}$ fraction in peat and its $\mathrm{C} / \mathrm{N}$ ratio, as observed in a 7-year fertilization experiment (Bragazza et al., 2012). The model also successfully simulated the maintenance of total PFT biomass and production with dramatic changes in the PFT composition, as observed in many $\mathrm{N}$ fertilization experiments (Bubier et al., 2007; Juutinen et al., 2010).

Uptake of DON, which has not been considered in peatland models previously, represented a negligible fraction (ca. $0.2 \%$ ) of the total $\mathrm{N}$ uptake by the roots of vascular plants. However, the turnover rate of DON was extremely high, revealing the strong demand and potential uptake of DON by the roots of vascular plants. The fast turnover rate (Kielland et al., 2007) and the large potential uptake of DON (Kahmen et al., 2009) were previously reported from field experiments on boreal forest and three intermediate $\mathrm{N}$ available systems, respectively. The model showed that the primary limitation on the uptake of DON was the DON concentration in the soil water, which was also suggested for boreal forest (Kielland et al., 2006) and for Anthoxanthum odoratum in a fertilized experimental site (Sauheitl et al., 2009). Consequently, DON uptake will be more important when there is more bio-available DON in the soil. Although not shown here, the DON uptake accounted for $16 \%$ of the total $\mathrm{N}$ uptake of shrubs after $40 \mathrm{yr}$ of $\mathrm{N}$ deposition of $1.5 \mathrm{gN} \mathrm{m}^{-2} \mathrm{yr}^{-1}$ in the $\mathrm{N}$ saturation simulation.

The nitrogen saturation simulation further showed that the impact of $\mathrm{N}$ deposition developed only after a considerable time lag (Fig. 11). Except for mineralization and $\mathrm{N}$ output, the $\mathrm{C}$ and $\mathrm{N}$ pools and fluxes remained stable in the first 12 simulation years until $\mathrm{N}$ became saturated in mosses. Only after that point, the $\mathrm{N}$ retention in vascular plants and peat increased dramatically and changed the peatland into grass dominated within $8 \mathrm{yr}$. A delay of $12 \mathrm{yr}$ in the occurrence of effects of $\mathrm{N}$ fertilization reveals the importance of accumulated $\mathrm{N}$ deposition rather than annual $\mathrm{N}$ deposition.

\section{Conclusions}

The PEATBOG model has been developed for the purpose of analyzing coupled $\mathrm{C}$ and $\mathrm{N}$ cycling on a process-level and a daily to multi-year timescale. Our objective was to conceptually consistently integrate vegetation, soil biogeochemistry and soil water dynamics. The model was further designed to be sensitive to changes in $\mathrm{N}$ deposition, temperature and precipitation. PEATBOG thus integrates a vegetation submodel comprising three PFTs with a soil and water biogeochemical model providing high spatial and process resolution. It consistently emphasizes mass balance principles and the dynamic interplay of production, consumption and translocation of materials throughout the ecosystem. PEATBOG is able to generate soil physical conditions and plant composition internally and thus requires only a few site specific parameters on geological location, local climate and initial vegetation composition for simulations. The PEATBOG model was effective in reproducing current $\mathrm{C}$ and $\mathrm{N}$ cycles in a northern peatland with some weaknesses in displaying correct short-term dynamics of $\mathrm{C}$ cycling during extreme meteorological periods. It was adequately sensitive to broader changes in climate and $\mathrm{N}$ deposition and reproduced a considerable range of empirical findings related to effects of inter annual meteorological variability and $\mathrm{N}$ deposition (e.g. the temperature control on soil respiration, change in PFT composition while total C pool and NPP in plants remained robust).

In this paper we presented the components and structure of the model and evaluated the general model performance and sensitivity. The sensitivity analyses and the simulation of increased $\mathrm{N}$ deposition demonstrated the model's utility in analyzing the effects of climate change and $\mathrm{N}$ deposition on the $\mathrm{C}$ and $\mathrm{N}$ cycles of peatlands. The analyses further illustrated its usefulness in hypothesis-building that could assist in designing empirical studies examining ecosystem changes over the long term.

In terms of application, the model is suitable for investigating the mechanisms of observed changes in peatland $\mathrm{C}$ and $\mathrm{N}$ fluxes due to changes in meteorological drivers and $\mathrm{N}$ input. Alternatively, the model could be a tool for assessing long-term scenarios of global change. The multi-layer structure of the soil submodel also allows for the integration of other belowground processes in the future, such as $\mathrm{SO}_{4}^{2-}$ reduction, to explicitly model $\mathrm{CH}_{4}$ production on account of the competition among electron acceptors. Although the $\mathrm{CH}_{4}$ production was modeled conceptually from an electron competition perspective, which we did not detail in this paper, it also produced reasonable annual fluxes and depth profiles of $\mathrm{CH}_{4}$ concentration, which hold promise for future analyses of $\mathrm{CH}_{4}$ dynamics. 


\section{Appendix A}

\section{Equations}

\section{A1 Environment submodel}

$d_{i}=$ distance between the adjacent layers $(\mathrm{m}), i=$ layer number, $f=$ factors, frac $=$ fraction, $\mathrm{PAI}=$ plant leaf area index $\left(\mathrm{m}^{2}\right), V_{i}=$ volume of layer $i\left(\mathrm{~m}^{3}\right)$, VWC $=$ volumetric water content $\left(\mathrm{m}^{3} \mathrm{~m}^{-3}\right), z_{i}=$ depth of layer $i(\mathrm{~m})$.

$\mathrm{WS}(t)=$ Pre + Snow - EPT - Runoff

$\mathrm{EPT}=f_{\mathrm{WT}, \mathrm{EPT}} \cdot f_{\mathrm{PAI}, \mathrm{EPT}} \cdot f_{T, \mathrm{EPT}} \cdot \mathrm{PAR} \cdot r$ _EPT ${ }_{0}$

$f_{\text {PAI_EPT }}=1-e^{-\mathrm{PAI}}$

Runoff $=$

$\left\{\right.$ Transmissivity $\cdot$ local_slope $\cdot(\mathrm{WT}-0.75)$ if Pre + Snow $+\mathrm{WS}<\mathrm{WS}_{\max }$

Advection $=$ Advection_frac $\cdot$ Runoff

runoff $_{L, i}=($ Runoff - Advection $) \cdot \mathrm{Kh}_{i} / \sum_{i} \mathrm{Kh}_{i}$

$\mathrm{Kh}_{i}=10^{f \text { saturated_Kh }_{i}+f \mathrm{VWC} \__{-} \mathrm{Kh}_{i}}$

$\mathrm{WT}=\left\{\begin{array}{cl}2 \cdot \mathrm{WS}-0.8 & \text { if } \quad \mathrm{WS}<0.2 \\ \mathrm{WS}-0.6 & \text { if } 0.2<\mathrm{WS}<0.6 \\ 0 & \text { if } \quad \mathrm{WS} \geq 0.6\end{array}\right.$

$\mathrm{VWC}_{i}=\mathrm{VWC}_{\min , i}+\left(\right.$ porosity $\left._{i}-\mathrm{VWC}_{\min , i}\right) /$

$\left(1+\alpha \mid \text { suction }\left.\right|^{n}\right)^{(1-1 / n)}$

Suction $_{i}=\left\{\begin{array}{cc}\left(z_{i}-\mathrm{WT}\right)+\text { Suction_saturated }_{i} & \text { if } z_{i}>\mathrm{WT} \\ \text { Suction_saturated } & \text { else }\end{array}\right.$

Porosity $_{i}=\left(1-0.0107 \cdot\left(-z_{i} \cdot 100\right)^{0.507}\right) / 1.5$

$\mathrm{O}_{2, i}(t)=\mathrm{O}_{2} \operatorname{diff}_{\text {top }, i}-\mathrm{O}_{2} \operatorname{diff}_{\text {bot }, i}-\mathrm{CO}_{2}$ pro $_{i}$

$-2 \cdot \mathrm{CH}_{4}$ oxi_ $\mathrm{O}_{2, i}$

$T(z, t)=\mu_{T}+\sigma_{T} f_{\text {snow }}$

$\exp \left(\sqrt{\frac{\pi z_{i}^{2}}{\Omega K_{\text {thermal }, i}}}\right) \sin \left(\frac{2 \pi\left(t-t_{l}\right)}{\Omega}+\sqrt{\frac{\pi z_{i}^{2}}{\Omega K_{\text {thermal }, i}}}\right)$

$\mathrm{DL}=360 \cdot \arccos (-\tan ($ Latitude $\cdot \pi / 180)$

$\cdot \tan ($ declination $\cdot \pi / 180)) / 15 \pi$

declination $=23.45 \cdot \sin (2 \pi \cdot(284+$ doy $) / 365)$

$\mathrm{WC}_{\text {cap }}(t)=$ rain_incepted moss $_{-}-\mathrm{EPT}_{\text {moss }}$

rain_incepted moss $_{\text {in }}=\min \left(\left(\mathrm{WC}_{\text {cap } \max }-\mathrm{WC}_{\text {capitulum }}\right)\right.$,

Pre $\left.\cdot \mathrm{LAI}_{\text {moss }} \cdot d_{\text {rain }} / B_{\text {sh,moss }}\right)$

$\mathrm{EPT}_{\text {moss }}=\left\{\begin{array}{cc}\mathrm{WC}_{\mathrm{cap}} \cdot \mathrm{EPT}_{2} r_{\mathrm{moss}} & \text { if Pre }=0 \\ 0 & \text { else }\end{array}\right.$

$\mathrm{WC}_{\text {moss }}=\mathrm{WC}_{\text {cap }}+$ capillary_rise

capillary rise $=$

$\max \left(\right.$ WCcap $_{\min }, \min \left(\right.$ WCcap $\left.\left._{\max }, 22 \cdot \exp ^{6.5 \cdot W T}\right)\right)$
$\mathrm{BD}_{i}=0.0107 \cdot\left(-100 \cdot d_{i}\right)^{0.567}$

PeatC $_{i}=\mathrm{BD}_{i} \cdot V_{i} \cdot 100^{3}$

DMinitial $_{i}=$ DMconc_initial $_{i} \cdot \mathrm{VWC}_{i} \cdot V_{i}$

Nabsorbed_moss $=$ Nload $\cdot r_{\_} \mathrm{N}_{\text {absorb }} / 365$

\section{A2 Vegetation}

$B=$ biomass,$\quad$ conc $=$ concentration, $\quad$ DIC $=\mathrm{CO}_{2} \mathrm{CH}_{4}$, $\mathrm{DIN}=\mathrm{NO}_{3}^{-}, \mathrm{NH}_{4}^{+}, j=$ plant functional type $j(1=$ mosses, $2=$ graminoids, $3=$ shrubs), $\quad \mathrm{li}=$ litter, $M=$ carbon or nitrogen, $\mathrm{Na}=$ area based nitrogen content $\left(\mathrm{gN} \mathrm{m}^{-2}\right)$, $Q=$ substrate or structural, reallo $=$ reallocation of carbon or nitrogen, $\mathrm{rec}=$ recycle, $\mathrm{Rm}=$ maintenance respiration, $\mathrm{Rg}=$ growth respiration, upt $=$ uptake, $X=\mathrm{sh}$, rt, stem, leaf, fineroot, coarse root.

$B_{X, j}=X$ strucC $_{j} /$ Cconc $_{j}$

$M \operatorname{conc}_{X, Q, j}=M_{X, Q, j} / B_{X, j}$

$\mathrm{rt} \_d i s t r i b_{i, j}=\left\{\begin{array}{cc}\mathrm{rt} \_k_{j}^{-100 \cdot z_{i-1}}-\mathrm{rt} \_k_{j}^{-100 \cdot z_{i}} & \text { if } i<i_{\text {rooting, }, j} \\ \mathrm{rt} \_k_{j}^{-100 \cdot z_{i}}-\mathrm{rt} \_k_{j}^{-100 \cdot z_{20} 0} & \text { if } i=i_{\text {rooting, }, j} \\ 0 & \text { else }\end{array}\right.$

$B_{\mathrm{rt}, i, j}=B_{\mathrm{rt}, j} \cdot$ rt_distrib ${ }_{i, j}$

$f B_{\mathrm{rt}, i, j}=B_{\mathrm{rt}, j} \cdot \mathrm{rt}_{-} \operatorname{distrib}_{i, j} / \sum_{j} B_{\mathrm{rt}, j}$

li_ $M_{\mathrm{rt}, q, i}=\mathrm{Li}_{-} \operatorname{frac}_{q} \cdot \sum_{j}\left(\mathrm{li}_{-} M_{\mathrm{rt}, j} \cdot \mathrm{rt} \_\operatorname{distrib}_{i, j}\right)$

finertS $_{i, j}=0.01 \cdot$ finert $_{i, j} \cdot \mathrm{PI} \cdot \mathrm{LV}_{j} /$ density $_{\text {finert }_{j}}$

$\mathrm{LV}_{j}=1 / \pi r_{\text {cylinder }, j}^{2}$

$M_{X, Q, j}(t)=\operatorname{growth} M_{X, j}-$ li_ $M_{X, j}$

li_C $\mathrm{C}_{\mathrm{sh}, \text { struc }, j}=\mathrm{C}_{\mathrm{sh}, \mathrm{struc}, j} \cdot r_{\text {mort }, \mathrm{sh}, j}$

$\cdot f_{T, \mathrm{sh}, j}+r_{\text {deciduous }} \cdot C_{\text {leaf }, \text { struc }, j}$

li_C $\mathrm{Crt}_{\mathrm{rt} \text { struc }, j}=\mathrm{C}_{\mathrm{rt}, \mathrm{struc}, j} \cdot r_{\mathrm{mort}, \mathrm{rt}, j} \cdot f_{T, \mathrm{rt}, j}$

li_ $\mathrm{N}_{X, \text { struc }, j}=\mathrm{li}_{-} \mathrm{C}_{X, \text { struc }, j} / \mathrm{CNratio}_{X, \text { struc }, j}$

$\mathrm{C}_{\mathrm{sh}, \text { subs }, j}(t)=$ CanopyPSN_C $_{j}+$ li_rec_C $\mathrm{C}_{\mathrm{sh}, j}$

- growthC $_{\mathrm{sh}, j}-$ li_C $_{-}$sh,subs, $j-\mathrm{Rm}_{\mathrm{sh}, j}$

$-\mathrm{Rg}_{\mathrm{sh}, j}-$ realloC $_{j}-\mathrm{exuC}_{\mathrm{sh}, j}$

CanopyPSN_C ${ }_{j}=$ leafPSN $_{j} \cdot$ DayLength

$\cdot\left(1-e^{-k_{\mathrm{ext}, j} \mathrm{LAI}_{j}}\right) / k_{\mathrm{ext}, j}$

$\mathrm{LAI}_{j}=\mathrm{SLA}_{j} \cdot \mathrm{C}_{\text {leaf, struc }, j}$

leafPSN $_{j}=$

$\left\{\alpha_{j} k_{\mathrm{ext}, i} \mathrm{LI}_{i}+P_{\max , j}=\right.$

$\left.\sqrt{\left[\left(\alpha_{j} k_{\mathrm{ext}, j} \mathrm{LI}_{j} P_{\max , j}\right)^{2}-4 \xi \alpha_{j} k_{\mathrm{ext}, j} \mathrm{LI}_{j} P_{\max , j}\right]}\right\}$

$\mathrm{LI}_{j}=$ 


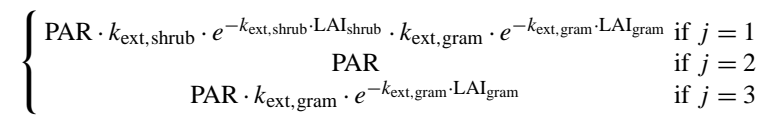

$\alpha_{j}=\alpha_{0} f_{\mathrm{CO}_{2}, \alpha, j} f_{T, \alpha, j} f_{m, \alpha, j}$

$f_{T, \alpha, j}=\left\{\begin{array}{cc}0 & \text { if } \\ \min \left(1-0.001125 \cdot\left(T_{\text {air }}-14\right), 1\right) & \text { else }\end{array}\right.$

$f_{\mathrm{CO}_{2}, \alpha}=1-0.3 \times 10^{-6} / 0.0015 \cdot \mathrm{CO}_{2, \text { air }}$

$f_{m, \alpha, j}=f_{M, P_{\max }, j}=\left\{\begin{array}{c}a_{m, \mathrm{sh}, j}^{2} \text { if } j>1 \\ f_{\mathrm{moss}, \mathrm{PSN}} \text { else }\end{array}\right.$

$P_{\max , j}=P_{\max , 20, j} f_{\mathrm{CO}_{2}, P_{\max }, j} f_{T, P_{\max }, j} f_{M, P_{\max }, j}$

$f_{\mathrm{gs}, P_{\max }} f_{\text {season, } P_{\max }} f_{\mathrm{N}, P \max , j}$

$f_{\mathrm{N}, P_{\max }, j}=$

$\int \max \left(0, \min \left(1, a_{\mathrm{PNUE}, j} \cdot \mathrm{Na}_{j}+b_{\mathrm{PNUE}, j}\right)\right)$ if

$j>1$

$\left\{\begin{array}{cl}\max \left(0, \min \left(1, a_{\mathrm{PNUE}, j} \cdot \mathrm{Na}_{j}+b_{\mathrm{PNUE}, j}\right)\right) & \text { if } \\ \max \left(0, \min \left(1, a_{\mathrm{PNUE}, j} \cdot \mathrm{Na}_{j}+b_{\mathrm{PNUE}, j}\right)\right) & \text { if } j=1 \cap \mathrm{Na}_{\mathrm{moss}}<\mathrm{Na}_{\text {max }} \text { moss } \\ f_{\mathrm{N}, \text { toxic }} & \text { else }\end{array}\right.$

$\mathrm{Na}_{j}=\mathrm{N}_{\mathrm{sh}, \text { subs }, j} / \mathrm{SLA}_{j}$

$\operatorname{Rm}_{X, j}=r \operatorname{Rm}_{X, j} \cdot \mathrm{C}_{X, \text { struc }, j} \cdot f_{m, X, j} \cdot f_{T, X, r, j}$

$f_{T, X, r, j}=Q_{10, X, r, j}^{\left(T_{\text {air }}-25\right) / 10}$

growthC $_{X, j}=\mathrm{C}_{X, \text { struc }, j} \cdot r_{-}$growth $_{X, j} \cdot f T_{X, j} \cdot \mathrm{fm}_{X, j} \cdot$

$k_{-}$growth $_{X, j}$.

Cconc $_{X, \text { subs, } j}$

Nconc $_{X, \text { subs, } j}$

$\overline{k_{m} \text { growthC }_{j}+\text { Cconc }_{X, \text { subs }, j}} \cdot \overline{k_{m} \text { growthN }_{j}+\text { Nconc }_{X, \text { subs }, j}}$ $f_{m, X, j}= \begin{cases}a_{m, X, j}^{20} & \text { if } j=2 \\ a_{m, X, j}^{10} \text { if } j=3\end{cases}$

$f_{T, j}=\left\{\begin{array}{cl}T_{j}^{q}\left(45-T_{j}\right) / T_{\text {ref }}(45-20) & \text { if } 0<T_{j}<45 \\ 0 & \text { else }\end{array}\right.$

$\operatorname{Rg}_{X, j}=$ growthC $_{X, j} \cdot\left(1-k_{\text {_growth }}, j\right) / k_{\text {_growth }}, j$

li_ $M_{X, \operatorname{subs}, j}=\operatorname{li} \__{-} B_{X, j} \cdot M \operatorname{conc}_{X, \operatorname{subs}, j} \cdot \operatorname{li} \__{-} M_{-} \operatorname{frac}_{X, \operatorname{subs}, j}$

li_C_frac $X$, subs, $j=$

$\left(\mathrm{li}_{-} \mathrm{C}_{-} \operatorname{frac}_{X, \operatorname{subs}, j, \min } k_{\mathrm{li}, \operatorname{subsC}}+\mathrm{Cconc}_{X, \operatorname{subs}, j}\right) /$

$\left(k_{\mathrm{li}, \text { subsC }}+\operatorname{Cconc}_{X, \text { subs }, j}\right)$

li_rec_C $\mathrm{C}_{X, \text { subs }, j}=$ li_recN $\mathrm{N}_{X \text {,subs, } j} \cdot \mathrm{CNratio}_{\mathrm{rec}}$

reallo $M_{j}=\mid M$ conc $_{\mathrm{sh}, \text { subs }, j}-M$ conc $_{\mathrm{rt}, \mathrm{subs}, j} \mid$

$/\left(\rho_{M, j} / B_{\mathrm{sh}, j}+\rho_{M, j} / B_{\mathrm{rt}, j}\right)$

$\mathrm{C}_{\mathrm{rt}, \text { subs, } j}(t)=$ realloC ${ }_{j}+$ li_rec_C $\mathrm{C}_{\mathrm{rt}, \text { subs }, j}$

$+\mathrm{Cupt}_{j}-\mathrm{li}_{-} \mathrm{C}_{\mathrm{rt}, \text { subs }, j}-$ growthC $_{\mathrm{rt}, j}-\mathrm{Rm}_{\mathrm{rt}, j}$

$-\mathrm{Rg}_{\mathrm{rt}, j}-\mathrm{exuC}_{\mathrm{rt}, j}$

$\operatorname{exuC}_{X, j}=r_{-} \operatorname{exu}_{X, j} \cdot \mathrm{fm}_{X, j} \cdot f T_{X, j} \cdot \mathrm{C}_{X, \mathrm{subs}, j}$

$\mathrm{Cupt}_{j}=\mathrm{Nupt}_{j} \cdot \mathrm{CNratio}_{\text {uptake }}$

$\mathrm{N}_{\mathrm{sh}, \operatorname{subs}, j}(t)=$

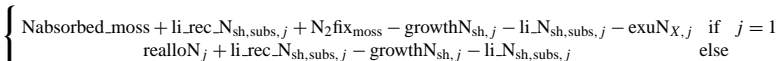

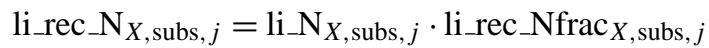

li_rec_Nfrac ${ }_{X, \operatorname{subs}, j}=$ li_rec_Nfrac $X, \operatorname{subs}, j,{ }_{\max } k_{\text {rec_subsN }}$ $/\left(\right.$ Nconc $\left._{X, \text { subs, } j}+k_{\text {rec_subsN }}\right)$

li_ $\mathrm{N}_{X, \text { subs }, j}=$ frac_li_ $\mathrm{N}_{X, \text { subs }, j} \cdot \mathrm{N}_{X, \text { subs }, j} \cdot \mathrm{li}_{-} B_{X, j}$

frac_li_ $\mathrm{N}_{X, \text { subs, } j}=$ frac_li_ $\mathrm{N}_{X, \text { subs }, j, \min } \cdot k_{\text {li_subsN }} /$

$\left(k_{\text {li_subsN }}+\right.$ Nconc $\left._{X, \text { subs }, j}\right)$

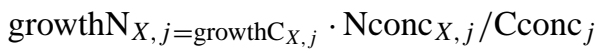

(A66)

$\mathrm{N}_{2} \mathrm{fix}_{\text {moss }}=$ fracN $_{2} \mathrm{fix}_{\text {moss }} \cdot$ TotalN $_{2}$ fix

$\operatorname{exuN}_{X, j}=\operatorname{exuC}_{X, j} / \mathrm{CNratio}_{X, \text { subs }, j}$

$\mathrm{N}_{\mathrm{rt}, \operatorname{subs}, j}(t)=$ li_rec_$\_\mathrm{N}_{\mathrm{rt}, \text { subs }, j}+\mathrm{Nupt}_{j}$

- realloN $_{j}-$ growthN $_{\mathrm{rt}, j}$

- li_N $\mathrm{N}_{\mathrm{rt}, \mathrm{subs}, j}-\mathrm{exuN}_{\mathrm{rt}, j}$

$\mathrm{Nupt}_{j}=$

$\left\{\left(\sum_{i}\right.\right.$ DONupt $_{i, j}+\sum_{i} \mathrm{NH}_{4}^{+} \mathrm{upt}_{i, j}+\sum_{i} \mathrm{NO}_{3}^{-}$upt $\left._{i, j}\right) \cdot 14 / 1000 \quad \begin{array}{l}\text { if } j=1 \\ \text { else }\end{array}$

DINupt $_{i, j}=$ DINupt_pot $_{i, j} \cdot f T_{\text {DINupt }, i} / f \mathrm{CN}_{\text {subs }, j}$

DINupt_pot ${ }_{i, j}=$

$\left\{\begin{array}{cc}0 & \text { if } i>i_{\text {rooting, }, j} \\ \mathrm{~V}_{\mathrm{m}, \mathrm{DIN}} \cdot \text { DINconc }_{i} \cdot \text { finertS }_{i, j} /\left(\mathrm{k}_{\mathrm{m}, \mathrm{DIN}}+\text { DINconc }_{i}\right) \text { else }\end{array}\right.$

$f T_{\mathrm{NH}_{4}^{+} \text {upt }, i, j}=\left\{\begin{array}{ccc}0 & \text { if } & T_{\text {soil }, i}<-5 \\ 0.2 T_{\text {soil }, i}+1 & \text { if } & -5<T_{\text {soil }, i}<0 \\ 1 & \text { if } & T_{\text {soil }, i}>0\end{array}\right.$

$f T_{\mathrm{NO}_{3}^{-} \text {upt }, i, j}=Q_{10, \mathrm{NO}_{3}^{-} \text {upt }}^{(T \text { soil },-10) / 10}$

$f \mathrm{CN}_{\text {subs }, j}=1+\mathrm{k}_{\mathrm{m}, \mathrm{C}, \mathrm{Nupt}} \cdot\left(1+\mathrm{Nconc}_{\mathrm{rt}, \text { subs }, j} / \mathrm{k}_{\mathrm{m}, \mathrm{N}, \mathrm{Nupt}}\right)$

$/$ Cconc $_{\mathrm{rt}, \text { subs, } j}$

(A76)

DONupt $_{j}=$

$\left\{\begin{array}{cc}0 & \text { if } i>i_{\text {rooting, } j}\end{array}\right.$

\section{A3 Soil organic matter}

act $=$ actual,$\quad$ avail $=$ available,$\quad \operatorname{dec}=$ decomposition, min $\_$immo $=$mineralization or immobilization, pot $=$ potential, trans $=$ transfer, $q=$ labile or recalcitrant.

$\operatorname{SOM} X_{q, i}(t)=\operatorname{li} X_{\mathrm{rt}, q, i}+X \operatorname{trans}_{\mathrm{top}, q, i}$

$-X$ trans $_{\text {bot }, q, i}-\operatorname{decXact}_{q, i}$

Ctrans $_{\text {top }, q, i}=\left\{\begin{array}{cc}\text { li_. }_{\mathrm{sh}, q} & \text { if } i=1 \\ \text { Ctrans }_{\text {bot }, q, i-1} & \text { else }\end{array}\right.$

Ntrans $_{\text {top }, q, i}=\left\{\begin{array}{cl}\mathrm{li}_{-} \mathrm{N}_{\mathrm{sh}, q} & \text { if } \quad i=1 \\ \mathrm{Ctrans}_{\mathrm{top}, q, i} / \mathrm{CNratio}_{q, i} & \text { if } \operatorname{Ctrans}_{\mathrm{top}, q, i}>0 \\ \mathrm{Ctrans}_{\mathrm{top}, q, i} / \mathrm{CNratio}_{q, i+1} & \text { if } \mathrm{Ctrans}_{\mathrm{top}, q, i} \leq 0\end{array}\right.$

Ctrans $_{\text {bot }, q, i}=\left\{\begin{array}{c}\operatorname{Ctrans}_{i} \cdot \text { SOM_frac }_{q, i} \quad \text { if } \text { Ctransfer }_{i}>0 \\ \operatorname{Ctrans}_{i} \cdot \text { SOM_frac }_{q, i+1} \text { else }\end{array}\right.$

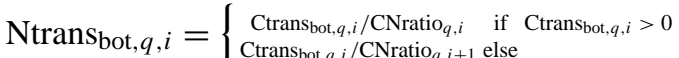

Ctransfer $_{i}=\mathrm{SOMCL}_{i}+\mathrm{SOMCR}_{i}-\mathrm{PeatC}_{i}$

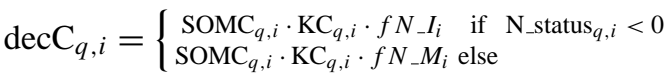


N_status $_{q, i}=1 /$ CNratio $_{q, i}-1 / \mathrm{CNcritical}_{q, i}$

(A85)

$\mathrm{CNcritical}_{q, i}=\mathrm{CN}_{\mathrm{mo}} \cdot \alpha_{E} \operatorname{Nprefer}_{q, i} / e_{q}$

$/(1-\mathrm{LeaDOC} \%)$

$\mathrm{KC}_{q, i}=\mathrm{KCpot}_{q} \cdot f T \operatorname{decC}_{q, i} \cdot f M \operatorname{decC}_{q, i}$

- finhibi_ $\mathrm{CO}_{2, i} \cdot$ finhibi_ $\mathrm{CH}_{4, i}$

finhibi $_{\text {DIC } i}=\left\{\begin{array}{cl}\text { finhibi } \text { DIC }_{\text {pot }_{i}} & \text { if } i>i_{\mathrm{WT}} \\ 1 & \text { else }\end{array}\right.$

Navail $_{i}=\left(\mathrm{NH}_{4, i}^{+}+\mathrm{NO}_{3, i}^{-}\right) \cdot 14 / 1000$

$\operatorname{decDOC}_{q, i}=\operatorname{decC}_{q, i} *$ LeaDOC\%

decCmicro_growth ${ }_{q, i}=\operatorname{decC}_{q, i} \cdot(1-\mathrm{LeaDOC} \%) \cdot e_{q}$

$e_{q}=6.25 \cdot$ Li_CNratio $_{q}^{-0.77}$

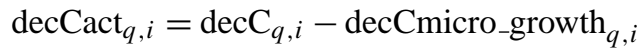

$\operatorname{decN}_{q, i}=\operatorname{decC}_{q, i} \cdot \alpha_{E}$ Nprefer $_{q, i} / \mathrm{CNratio}_{q, i}$

$\alpha_{E}$ Nprefer $_{q, i}=$ LeaDOC $\%$

$+(1-\mathrm{LeaDOC} \%)$

$\cdot\left(1+e_{q} \cdot\left(\mathrm{CN}_{\text {limit }} / \mathrm{CN}_{\mathrm{mo}}-1\right)\right)$

$\operatorname{decDON}_{q, i}=$

$\operatorname{decC}_{q, i} \cdot \alpha_{E}$ Nprefer $_{q, i} \cdot{\text { LeaDON} \% / \text { Nratio }_{q, i}}$

decNmicro_growth ${ }_{q, i}=$ decCmicro_growth $_{q, i} / \mathrm{CN}_{m o}$

$\mathrm{Nmin} \_\operatorname{immo}_{q, i}=\operatorname{dec}_{q, i}-\operatorname{decDON} \mathrm{N}_{q, i}$

- decNmicro_growth ${ }_{q, i}$

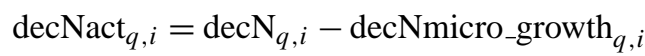

\section{A4 Dissolved C and N}

$\operatorname{adv}=$ advection, afp $=$ air filled porosity $\left(\mathrm{m}^{3} \mathrm{~m}^{-3}\right)$, $\mathrm{aq}=$ aquatic phase, $g=$ gaseous phase, $\mathrm{dep}=$ deposition, diff = diffusion, $\quad \mathrm{DM}_{\mathrm{g}}=$ dissolved gases $\left(\mathrm{CO}_{2}, \mathrm{CH}_{4}\right.$, $\mathrm{O}_{2}$ ), $\mathrm{DM}_{\mathrm{s}}=$ dissolved solutes (dissolved organic matter, $\left.\mathrm{NO}_{3}^{-}, \mathrm{NH}_{4}^{+}\right), \mathrm{SO}_{4}^{2-}\left(\mathrm{mmol} \mathrm{m}^{-2}\right)=\mathrm{SO}_{4}^{2-}$ in $1 \mathrm{~m}^{2}$ of Peat, $\mathrm{H}_{2} \mathrm{~S}\left(\mathrm{mmol} \mathrm{m}^{-2}\right)=\mathrm{H}_{2} \mathrm{~S}$ in $1 \mathrm{~m}^{2}$ of Peat, $\mathrm{EA}_{\mathrm{HS}, i}$ eq. $(\mathrm{mmolm})^{-2}=$ the oxidized dissolved humic substances serving as electron accepter (DOM-Q) in layer $i, \mathrm{ED}_{\mathrm{HS}, i}$ $(\mathrm{mmolm})^{-2}=$ the reduced dissolved humic substance that serves as electron donor (DOM-QH2) in layer $i$, doy $=$ day of year.

$\mathrm{DM}_{g}$ conc $_{\mathrm{aq}}=$

$\mathrm{DM}_{\mathrm{g}}$ conc $_{i} \cdot$ ratio $_{a q, g} \mathrm{DM}_{\mathrm{g}, i} /\left(1+\right.$ ratio $\left._{\mathrm{aq}, \mathrm{g}} \mathrm{DM}_{\mathrm{g}, i}\right)$

$\mathrm{DM}_{\mathrm{g}} \operatorname{conc}_{\mathrm{g}, i}=\mathrm{DM}_{\mathrm{g}}$ conc $_{i} / 1+$ ratio $_{\mathrm{aq}, \mathrm{g}} \mathrm{DM}_{\mathrm{g}, i}$

ratio $_{\text {aq, }} \mathrm{DM}_{\mathrm{g}, i}=K_{H, \mathrm{DM}_{\mathrm{g}, i}} \mathrm{rt} \cdot \mathrm{VWC}_{i} / \mathrm{afp}_{i}$

$K_{H, \mathrm{DM}_{\mathrm{g}}, i}=K_{H, \mathrm{DM}_{\mathrm{g}}, i}^{0}$.

$e^{-\mathrm{C}_{H, \text { inv, } \mathrm{DMg}}\left(1 / T-1 / T_{25}\right)} / 101.325$

(A103) $\left\{\begin{array}{clc}0 & \text { if } \quad i=20 \\ \mathrm{DM}_{s, i-1} \cdot\left(\mathrm{DM}_{\mathrm{s}} \operatorname{conc}_{i-1}-\mathrm{DM}_{\mathrm{s}} \operatorname{conc}_{i}\right) / d_{i} & \text { if } i<20 \cap \mathrm{DM}_{\mathrm{s}} \operatorname{conc}_{i-1}<\mathrm{DM}_{\mathrm{s}} \operatorname{conc}_{i} \\ \mathrm{DM}_{\mathrm{s}, i-1} \cdot\left(\mathrm{DM}_{\mathrm{s}} \operatorname{conc}_{i-1}-\mathrm{DM}_{\mathrm{s}} \operatorname{conc}_{i}\right) / d_{i-1} & \text { if } i<20 \cap \mathrm{DM}_{\mathrm{s}} \operatorname{conc}_{i-1} \geq \mathrm{DM}_{\mathrm{s}} \operatorname{conc}_{i}\end{array}\right.$

(A104)

$D_{\mathrm{DM}_{\mathrm{s}, i}}=D_{\mathrm{DM}_{0}} * \mathrm{VWC}_{i}^{2}$

DMgdiff_sat $u_{i}=$

$\int \max \left(0,\left(\mathrm{DM}_{\mathrm{g}} \operatorname{conc}_{i}-\mathrm{DM}_{\mathrm{g}} \operatorname{conc}_{\mathrm{atm}}\right) \cdot D_{\mathrm{DM}_{\mathrm{g}, i} / d_{i} \text { if }} \quad i=1\right.$

$\left(\mathrm{DM}_{\mathrm{g}} \mathrm{conc}_{i}-\mathrm{DM}_{\mathrm{g}} \mathrm{conc}_{i-1}\right) \cdot D_{\mathrm{DM}_{\mathrm{g}, i} / d_{i}}$ if $i>1 \cap \mathrm{DMg}_{\mathrm{g}} \operatorname{conc}_{i} \geq \mathrm{DM}_{\mathrm{g}} \operatorname{conc}_{i-1}$

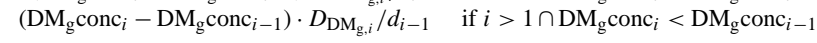

$D_{\mathrm{DM}_{\mathrm{g}, i}}=D_{\mathrm{DM}_{\mathrm{g}, \mathrm{aq} 0}} \cdot$ porosity $^{2}$

(A107)

$\operatorname{DOC}_{i}(t)=$ DOCpro $_{i}+$ DOCadv $_{\text {top }, i}+$ DOCdiff $_{\text {top }, i}$

- DOCadv $_{\text {bot }, i}-$ DOCdiff $_{\text {bot }, i}-$ DOCrunoff $_{h, i}$

- DOCupt $_{i}$

DOCupt $_{i}=\sum_{j}$ DONupt $_{j, i} \cdot \mathrm{CN}_{\text {DOM }}$

$\mathrm{CO}_{2, i}(t)=\mathrm{CO}_{2}$ pro $_{i}+\mathrm{CO}_{2}$ oxiCH $_{4, i}+\mathrm{CO}_{2}$ diff top,$i$

$+\mathrm{CO}_{2} \operatorname{adv}_{\text {top }, i}-\mathrm{CO}_{2} \operatorname{diff}_{\text {bot }, i}-\mathrm{CO}_{2} \operatorname{diff}_{\text {bot }, i}$

$-\mathrm{CO}_{2}$ runoff $_{h, i}$

$\mathrm{CO}_{2} \mathrm{pro}_{i}=\left\{\begin{array}{cc}R_{\mathrm{rt}, i}+\sum_{q} \operatorname{decDIC}_{q, i} & \text { if } \mathrm{O}_{2} \text { status }=1 \\ R_{\mathrm{r}, i}+\left(\sum_{q} \operatorname{dec}_{q} C_{q, i}+\mathrm{EACO}_{2} \mathrm{pro}_{i}\right) / 2 & \text { else }\end{array}\right.$

$R_{\mathrm{rt}, i}=\sum_{j}\left(\left(\operatorname{Rg}_{\mathrm{rt}, j}+\mathrm{Rm}_{\mathrm{rt}, j}\right) \cdot \mathrm{rt}_{-} \operatorname{distri}_{i, j}\right) \cdot 1000 / 12$

$\mathrm{CH}_{4, i}(t)=\mathrm{CH}_{4} \mathrm{pro}_{i}-\mathrm{CH}_{4}$ Planttrans $_{i}-\mathrm{CH}_{4} \mathrm{Oxi}_{i}$

$+\mathrm{CH}_{4} \operatorname{diff}_{\text {top }, i}+\mathrm{CH}_{4} \operatorname{adv}_{\text {top }, i}-\mathrm{CH}_{4} \operatorname{diff}_{\text {bot }, i}$

$-\mathrm{CH}_{4} \mathrm{adv}_{\mathrm{bot}, i}-\mathrm{CH}_{4} \mathrm{runoff}_{h, i}-\mathrm{CH}_{4} \mathrm{ebu}_{i}$

$\mathrm{CH}_{4} \mathrm{pro}_{i}=\left(\right.$ DecDIC $\left._{i}-\mathrm{EACO}_{2} \mathrm{pro}_{i}\right) \cdot\left(1-\mathrm{O}_{2}\right.$ status $\left._{i}\right) / 2$

$\mathrm{CH}_{4}$ Planttrans $_{i}=\mathrm{CH}_{4, i} \cdot k_{\text {Planttrans }} \cdot$ ffinert $B_{i, \text { gram }}$

. $\left(1-\right.$ Oxi_frac_trans $\left._{i}\right)$

(A115)

$k_{\text {Planttrans }, i}=\max \left(1,1.2 \cdot\right.$ ffinert $\left.B_{i, \text { gram }}\right)$

$\mathrm{CH}_{4} \mathrm{Oxi}_{i}=$ oxi_frac_trans ${ }_{i}$

- $\mathrm{CH}_{4}$ Planttrans $_{i}+\mathrm{CH}_{4} \mathrm{OxiO}_{2, i}$

$\mathrm{CH}_{4} \mathrm{OxiO}_{2, i}=V_{\mathrm{m}, \mathrm{CH}_{4} \mathrm{Oxi}} \cdot \mathrm{CH}_{4}$ conc $_{i} \cdot \mathrm{O}_{2}$ conc $_{i}$

- $Q_{10, \mathrm{CH}_{4} \text { oxi }}^{\left(T_{i}-4\right) / 10} \cdot \mathrm{O}_{2}$ status $_{i} /\left(\mathrm{CH}_{4}\right.$ conc $\left._{i}+\mathrm{K}_{\mathrm{m}, \mathrm{CH}_{4} \text { oxi }}\right)$

$/\left(\mathrm{O}_{2}\right.$ conc $\left._{i}+\mathrm{K}_{\mathrm{m}, \mathrm{O}_{2} \text { oxi }}\right)$

$\mathrm{CH}_{4} \mathrm{ebu}_{i}=k_{\mathrm{ebu}} \cdot \max \left(0,\left(\mathrm{CH}_{4} \mathrm{Conc}_{i}-\mathrm{CH}_{4} \mathrm{conc}_{\max }\right)\right) \cdot V_{i}$

$\mathrm{CH}_{4, \text { max }, i}=\mathrm{CH}_{4, \text { max }, i}(T) \cdot P_{i}$

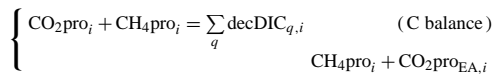

OtherEA $_{i}=5 \cdot \mathrm{N}_{2}$ denitri $_{i}+4 \cdot \mathrm{N}_{2}$ Odenitri $_{i}$

$+3 \cdot \mathrm{NO}_{\text {denitri }}+8 \cdot \mathrm{SO}_{4}^{2-}$ reduction

$\mathrm{SO}_{4}^{2-}(t)=S$ depo $-\mathrm{S}_{\text {runoff }}-\mathrm{S}_{\text {Peat }}-\mathrm{S}_{\text {plants }}$

- Sreduction $+\mathrm{H}_{2} \mathrm{~S} \_$oxidation

$\mathrm{S}_{\text {runoff }}=$ runoff $\cdot S$ conc

$S$ conc $=\mathrm{SO}_{4}^{2-} / \sum_{i} \mathrm{WC}_{i}$

$S_{\text {Peat }}=\Delta$ PeatC $\cdot 1000 /$ CSratio $_{\text {Peat }} / 32$

(A126)

$\mathrm{DM}_{s} \operatorname{diff}_{\mathrm{bot}, i}=$ 
$\mathrm{S}_{\text {plants }}=\Delta$ PlantC $\cdot \mathrm{SCratio}_{\text {plant }} \cdot 1000 / 32$

(A127)

$\mathrm{H}_{2} \mathrm{~S} \_$oxidation $=\mathrm{SO}_{4}^{2-}$

$\cdot e^{-}$faction $_{\mathrm{S}} \cdot \sum_{i} I_{\text {nanowire }, i} / 8+\mathrm{H}_{2} \mathrm{~S} \cdot r_{-}$oxi_SO $\mathrm{SO}_{4}^{2-}$

Sreduction $=$

$r$ red_SO $\mathrm{SO}_{4}^{2-} \cdot \mathrm{SO}_{4}^{2-} \cdot$ finhibi_ $\mathrm{CO}_{2, i}$

$\mathrm{H}_{2} \mathrm{~S}(t)=$ Sreduction $-\mathrm{H}_{2}$ Srelease

$\mathrm{H}_{2} \mathrm{Sconc}=\mathrm{H}_{2} \mathrm{~S} / \sum_{i} \mathrm{WC}_{i}$

$\mathrm{H}_{2}$ Srelease $=\mathrm{H}_{2} \mathrm{~S} \cdot r \mathrm{H}_{2} \mathrm{~S} \_$release

$\mathrm{EA}_{\mathrm{HS}, i}(t)=$ oxidation $_{i}-$ reduction $_{i}$

$\mathrm{ED}_{\mathrm{HS}, i}(t)=$ reduction $_{i}-$ oxidation $_{i}$

reduction $_{i}=r$ red_HS

$\cdot$ EA $_{\mathrm{HS}, i} \cdot$ finhibi $_{\mathrm{CO}_{2} i} \cdot\left(1-\mathrm{O}_{2}\right.$ status $\left._{i}\right)$

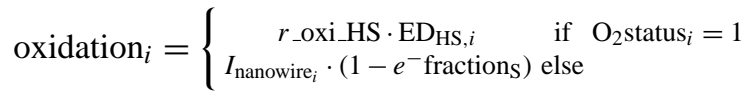

$I_{\text {nanowire }, i}=\operatorname{frac} 3600 \cdot 24 \cdot \mathrm{CN}_{A}$

- fracd $E h_{i} R_{i} \cdot\left(1-\mathrm{O}_{2}\right.$ Status $\left._{i}\right)$

$d E h_{i}=E h_{i}-E h_{i-1}$

$E h_{i}=$ frac $-\Delta G_{r, i} \cdot 1000 n \cdot F$

$\Delta G_{r, i}=\Delta G_{r, i}^{0}+\mathrm{rt}_{i} \ln K_{\mathrm{HM}, i}$

$K_{\mathrm{HM}, i}=\left\{\begin{array}{cc}0 & \text { if } H_{2} \text { conc }_{i}=0 \\ \text { fracCH}_{4} \operatorname{conc}_{i} \mathrm{CO}_{2} \text { conc }_{i} \cdot H_{2} \text { conc }_{i}^{4} \text { else }\end{array}\right.$

$R_{i}=\left|z_{i}\right| \cdot \mathrm{VWC}_{i} \cdot$ specific_resistance

$\mathrm{EA}_{\mathrm{HS}, i}$ initial $=\mathrm{ED}_{\mathrm{HS}, i}$ initial $=1.2 \cdot \sum_{q} \mathrm{SOMC}_{i} / 12$

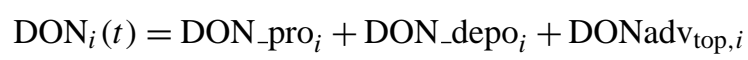

+ DONdiff $_{\text {top }, i}-$ DONadv $_{\mathrm{bot}, i}-$ DONdiff $_{\mathrm{bot}, i}$

- DONrunoff $_{h, i}-$ DONupt $_{i}$

$\mathrm{DONpro}_{i}=\sum_{q} \operatorname{decDON}_{q, i} * 1000 / 14$

$\mathrm{NH}_{4_{i}^{+}}(t)=\mathrm{NH}_{4}^{+} \mathrm{depo}_{i}+\sum_{q} \mathrm{Nmin} \_\mathrm{immo}_{q, i}$

$+\mathrm{DIN}_{-} \mathrm{fix}_{i}+\mathrm{NH}_{4}^{+} \operatorname{diff}_{\text {top }, i}+\mathrm{NH}_{4}^{+} \mathrm{adv}_{\text {top }, i}$

$-\mathrm{NH}_{4}^{+}$diff $\mathrm{bot}, i-\mathrm{NH}_{4}^{+} \mathrm{adv}_{\mathrm{bot}, i}$

$-\mathrm{NH}_{4}^{+}$upt $_{i}-\mathrm{NO}_{3}^{-} \mathrm{Nitri}_{i}-\mathrm{N}_{2}$ Onitri $_{i}-\mathrm{NOnitri}_{i}-$ $\mathrm{NH}_{4}^{+} \operatorname{runoff}_{h, i}$

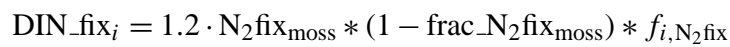

$\mathrm{N}_{2} \mathrm{fix}_{\text {moss }, i}=k_{\mathrm{fix}} * f T_{\mathrm{fix}, i} * f$ season $_{\mathrm{N}_{2} \mathrm{fix}} * f N_{\mathrm{N}_{2} \text { fix }}$

$f T$ fix $_{i}=\left\{\begin{array}{cc}0 & \text { if } \\ Q_{\text {moss }}<T_{\min , \text { fix }} \\ \left.Q_{10, \text { fix }}-21\right) / 10 & \text { else }\end{array}\right.$

$f$ season $\mathrm{N}_{2}$ fix $=15-0.1377 *$ doy $+0.0003264 *$ doy $^{2}$

$\mathrm{NO}_{3}^{-}$nitri $_{i}=\mathrm{NH}_{4}^{-}$conc $_{i} * V_{\mathrm{m}, \text { nitri }}$

$* \mathrm{NH}_{4_{i}^{-}} * f M_{\text {nitri }, i} * f T_{\text {nitri }, i} * f p \mathrm{H}_{\text {nitri }, i} * \mathrm{O}_{2}$ status $_{i}$
$/\left(\mathrm{NH}_{4}^{-}\right.$conc $\left._{i}+\mathrm{K}_{\mathrm{m}, \text { nitri }}\right)$

$(\mathrm{A} 151)$

$f T_{\text {nitri }, i}=\left(\text { frac } 60-T_{i} 25.78\right)^{3.503}$

. $\exp \left(3.503 * \operatorname{frac} T_{i}-34.2225 .78\right)$

(A152)

$f p \mathrm{H}_{\text {nitri, } i}=0.5 p H_{i}-2$

$\mathrm{NOnitri}_{i}=\mathrm{NO}_{3}^{-}$nitri $_{i} \cdot r \mathrm{NO}_{\text {nitri }} * f T_{\text {nitri, } i} * f M_{\text {nitri, }, i}$

$\mathrm{N}_{2}$ Onitri $_{i}=\mathrm{NO}_{3}^{-}$nitri $_{i} \cdot r \mathrm{~N}_{2} \mathrm{O}_{\text {nitri }} * f T_{\text {nitri }, i} * f M_{\text {nitri }, i}$

$\mathrm{NO}_{3, i}^{-}(t)=\mathrm{NO}_{3}^{-} \mathrm{depo}_{i}+\mathrm{NO}_{3}^{-}$nitri $_{i}+\mathrm{NO}_{3}^{-} \mathrm{adv}_{\text {top }, i}$

$+\mathrm{NO}_{3}^{-} \operatorname{diff}_{\mathrm{top}, i}-\mathrm{NO}_{3}^{-} \operatorname{adv}_{\mathrm{bot}, i}-\mathrm{NO}_{3}^{-} \operatorname{diff}_{\mathrm{bot}, i}$

$-\mathrm{NO}_{3}^{-}$upt $_{i}-\mathrm{N}_{2}$ Odenitri $_{i}-\mathrm{NO}_{3}^{-} \operatorname{runoff}_{h, i}$

$\mathrm{NO}_{3}^{-}$denitri $_{i}=V_{\mathrm{m} \text {,denitri }} \cdot \mathrm{NO}_{3}^{-} \operatorname{conc}_{i} \cdot f p \mathrm{H}_{\text {denitri }, i}$

$\cdot f T_{\text {denitri, } i} \cdot f M_{\text {denitri, } i} \cdot\left(1-\mathrm{O}_{2}\right.$ status $\left._{i}\right)$

$/\left(\mathrm{NO}_{3}^{-}\right.$conc $\left._{i}+k_{m, \text { denitri }}\right)$

$f T_{\text {denitri, } i}=\left\{\begin{array}{c}2^{\left(T_{i}-20\right) / 10} \text { if } T_{i}>10 \\ 0.5 \cdot 50^{\left(T_{i}-10\right) / 10} \text { else }\end{array}\right.$

$\mathrm{NO}_{2_{i}^{-}}(t)=\mathrm{NO}_{2}^{-}$denitri $_{i}-$ NOdenitri $_{i}$

$-\mathrm{N}_{2}$ Odenitri $_{i}-\mathrm{N}_{2}$ denitri $_{i}$

$\mathrm{N}_{2}$ denitri $_{i}=0.5 \cdot f T_{\text {denitri, } i} \cdot\left(1-\mathrm{O}_{2}\right.$ status $\left._{i}\right)$

$\cdot \mathrm{NO}_{2}^{-}$conc $_{i} /\left(\mathrm{NO}_{2}^{-}\right.$conc $\left._{i}+K_{m, \text { denitri }}\right)$

NOdenitri $_{i}=\mathrm{N}_{2}$ denitri $_{i} \cdot f T_{\text {denitri, } i} \cdot r \mathrm{NO}_{\text {denitri }}$

$\mathrm{N}_{2}$ Odenitri $_{i}=0.5 \cdot \mathrm{N}_{2}$ denitri $\cdot f T_{\text {denitri }, i}$

$\cdot r \mathrm{~N}_{2} \mathrm{O}_{\text {denitri }}$

(A162)

DMrunoff $_{\mathrm{h}, i}=$ DMconc $_{\mathrm{aq}, i} * \operatorname{runoff}_{i}$

\section{Supplementary material related to this article is available online at: http://www.geosci-model-dev.net/6/ 1173/2013/gmd-6-1173-2013-supplement.pdf.}

Acknowledgements. We greatly acknowledge useful discussions with J. Verhoeven, N. Dise, B. Svensson, B. Robroek, L. Bragazza and P. E. Lindgren that helped clarify concepts in the model development. We further thank T. R. Moore, P. Lafleur, N. T. Roulet and J. Bubier, S. Juutinen, E. R. Humphreys for facilitating access to data related to the Mer Bleue Peatland. This study is part of the BiodivERsA-PeatBOG project whose German subproject was funded by the German Ministry of Education and Research (BMBF) grant 01LC0819A to C. Blodau through ERA-net (European Union's 6thFramework).

For the model codes and the boundary condition files, please contact the corresponding author.

Edited by: A. Ridgwell

\section{References}

Aber, J. D. and Federer, C. A.: A generalized, lumped-parameter model of photosynthesis, evapotranspiration and net primary production in temperate and boreal forest ecosystems, Oecologia, 92, 463-474, 1992. 
Aber, J. D., Ollinger, S. V., and Driscoll, C. T.: Modeling nitrogen saturation in forest ecosystems in response to land use and atmospheric deposition, Ecol. Model., 101, 61-78, 1997.

Aerts, R., Wallen, B., and Malmer, N.: Growth-limiting nutrients in Sphagnum-dominated bogs subject to low and high atmospheric nitrogen supply, J. Ecol., 80, 131-140, 1992.

Aldous, A. R.: Nitrogen retention by Sphagnum mosses: Responses to atmospheric nitrogen deposition and drought, Can. J. Botany, 80, 721-731, doi:10.1139/b02-054, 2002.

Atkin, O.: Reassessing the nitrogen relations of arctic plants: A mini-review, Plant Cell Environ., 19, 695-704, 2006.

Aubin, I., Beaudet, M., and Messier, C.: Light extinction coefficients specific to the understory vegetation of the southern boreal forest, quebec, Can. J. Forest Res., 30, 168-177, 2000.

Bartsch, I. and Moore, T. R.: A preliminary investigation of primary production and decomposition in four Peatlands near Schefferville, Quebec, Can. J. Botany, 63, 1241-1248, 1985.

Baumgärtner, M. and Conrad, R.: Role of nitrate and nitrite for production and consumption of nitric oxide during denitrification in soil, FEMS Microbiol. Lett., 101, 59-65, 1992.

Bayley, S. E., Thormann, M. N., and Szumigalski, A. R.: Nitrogen mineralization and decomposition in western boreal bog and fen Peat, Ecoscience, 12, 455-465, doi:10.2980/i1195-6860-124-455.1, 2005.

Beer, J. and Blodau, C.: transport and thermodynamics constrain belowground carbon turnover in a northern Peatland, Geochim. Cosmochim. Acta, 71, 2989-3002, doi:10.1016/j.gca.2007.03.010, 2007.

Beer, J., Lee, K., Whiticar, M., and Blodau, C.: Geochemical controls on anaerobic organic matter decomposition in a northern Peatland, Limnol. Oceanogr., 53, 1393-1407, 2008.

Berendse, F., Van Breemen, N., Rydin, H. Å., Buttler, A., Heijmans, M., Hoosbeek, M. R., Lee, J. A., Mitchell, E., Saarinen, T., and Vasander, H.: Raised atmospheric $\mathrm{CO}_{2}$ levels and increased $\mathrm{N}$ deposition cause shifts in plant species composition and production in Sphagnum bogs, Glob. Change Biol., 7, 591-598, 2001.

Berg, B. and Staaf, H.: leaching, accumulation and release of nitrogen in decomposing forest litter, Ecological Bulletins, 163-178, 1981.

Billett, M. and Moore, T. R.: Supersaturation and evasion of $\mathrm{CO}_{2}$ and $\mathrm{CH}_{4}$ in surface waters at Mer Bleue Peatland, Canada, Hydrol. Process., 22, 2044-2054, 2007.

Blodau, C.: Thermodynamic control on terminal electron transfer and methanogenesis, ACS Symposium Series, 1071, 65-83, doi:10.1021/bk-2011-1071.ch004, 2011.

Blodau, C. and Moore, T. R.: Macroporosity affects water movement and pore water sampling in Peat soils, Soil Science, 167, 98-109, 2002.

Blodau, C., Roulet, N. T., Heitmann, T., Stewart, H., Beer, J., Lafleur, P., and Moore, T. R.: Belowground carbon turnover in a temperate ombrotrophic bog, Global Biogeochem. Cy., 21, GB1021, doi:10.1029/2005gb002659, 2007.

Blodau, C., Siems, M., and Beer, J.: Experimental burial inhibits methanogenesis and anaerobic decomposition in watersaturated Peats, Environ. Sci. Technol., 45, 9984-9989, doi:10.1021/es201777u, 2011.

Bond-Lamberty, B. and Gower, S. T.: Estimation of stand-level leaf area for boreal bryophytes, Oecologia, 151, 584-592, 2007.
Bragazza, L., Tahvanainen, T., Kutnar, L., Rydin, H., Limpens, J., Hajek, M., Grosvernier, P., Hajek, T., Hajkova, P., Hansen, I., Iacumin, P., and Gerdol, R.: Nutritional constraints in ombrotrophic Sphagnum plants under increasing atmospheric nitrogen deposition in Europe, New Phytologist, 163, 609-616, doi:10.1111/j.1469-8137.2004.01154.x, 2004.

Bragazza, L., Limpens, J., Gerdol, R., Grosvernier, P., Hájek, M., Hájek, T., Hajkova, P., Hansen, I., Iacumin, P., Kutnar, L., Rydin, H.. and Tahvanainen, T.: Nitrogen concentration and $\delta^{15} \mathrm{~N}$ signature of ombrotrophic Sphagnum mosses at different $\mathrm{N}$ deposition levels in Europe, Glob. Change Biol., 11, 106-114, 2005.

Bragazza, L., Freeman, C., Jones, T., Rydin, H., Limpens, J., Fenner, N., Ellis, T., Gerdol, R., Hajek, M., Hajek, T., Iacumin, P., Kutnar, L., Tahvanainen, T., and Toberman, H.: Atmospheric nitrogen deposition promotes carbon loss from Peat bogs, Proc. Natl. Aca. Sci. USA, 103, 19386-19389, doi:10.1073/pnas.0606629104, 2006.

Bragazza, L., Buttler, A., Siegenthaler, A., and Mitchell, E. A. D.: Plant litter decomposition and nutrient release in Peatlands, Geophys. Monogr. Ser., 184, 99-110, 2009.

Bragazza, L., Buttler, A., Habermacher, J., Brancaleoni, L., Gerdol, R., Fritze, H., Hanajík, P., Laiho, R., and Johnson, D.: High nitrogen deposition alters the decomposition of bog plant litter and reduces carbon accumulation, Glob. Change Biol., 18, 1163-1172, doi:10.1111/j.1365-2486.2011.02585.x, 2012.

Breeuwer, A., Heijmans, M., Robroek, B. J. M., Limpens, J., and Berendse, F.: The effect of increased temperature and nitrogen deposition on decomposition in bogs, Oikos, 117, 1258-1268, 2008.

Breuer, L., Kiese, R., and Butterbach-Bahl, K.: Temperature and moisture effects on nitrification rates in tropical rain-forest soils, Soil Sci. Soc. Am. J., 66, 834-844, 2002.

Bridgham, S. D., Updegraff, K., and Pastor, J.: Carbon, nitrogen, and phosphorus mineralization in northern wetlands, Ecology, 79, 1545-1561, 1998.

Brock, T. D.: Calculating solar radiation for ecological studies, Ecol. Model., 14, 1-19, 1981.

Bubier, J., Crill, P., Mosedale, A., Frolking, S. and Linder, E.: Peatland responses to varying interannual moisture conditions as measured by automatic $\mathrm{CO}_{2}$ chambers, Global Biogeochem. $\mathrm{Cy}$., 17, 1066, doi:10.1029/2002GB001946, 2003.

Bubier, J. L., Moore, T. R., and Bledzki, L. A.: Effects of nutrient addition on vegetation and carbon cycling in an ombrotrophic bog, Glob. Change Biol., 13, 1168-1186, doi:10.1111/j.13652486.2007.01346.x, 2007.

Bubier, J. L., Smith, R., Juutinen, S., Moore, T. R., Minocha, R., Long, S., and Minocha, S.: Effects of nutrient addition on leaf chemistry, morphology, and photosynthetic capacity of three bog shrubs, Oecologia, 167, 355-368, doi:10.1007/s00442-0111998-9, 2011.

Cannell, M. G. R. and Thornley, J. H. M.: N-poor ecosystems may respond more to elevated $\left[\mathrm{CO}_{2}\right]$ than $\mathrm{N}$-rich ones in the long term. A model analysis of grassland, Glob. Change Biol., 4, 431442, 1998.

Carslaw, H. S. and Jaeger, J. C.: Conduction of heat in solids, Oxford, Clarendon Press, 1959, 2nd Edn., 1, 510 pp., 1959.

Chapin III, F. and Shaver, G.: Differences in growth and nutrient use among arctic plant growth forms, Functional Ecol., 3, 73-80, 1989. 
Clein, J. S. and Schimel, J. P.: Microbial activity of tundra and taiga soils at sub-zero temperatures, Soil Biol. Biochem., 27, 12311234, 1995.

Clymo, R.: The limits to Peat bog growth, Philos Trans. Roy. Soc. London. B, 303, 605-654, 1984.

Conant, R. T., Drijber, R. A., Haddix, M. L., Parton, W. J., Paul, E. A., Plante, A. F., Six, J., and Steinweg, J. M.: Sensitivity of organic matter decomposition to warming varies with its quality, Glob. Change Biol., 14, 868-877, doi:10.1111/j.13652486.2008.01541.x, 2008.

Conant, R. T., Haddix, M., and Paustian, K.: Partitioning soil carbon responses to warming: Model-derived guidance for data interpretation, Soil Biol. Biochem., 42, 2034-2036, 2010.

Conrad, R.: Contribution of hydrogen to methane production and control of hydrogen concentrations in methanogenic soils and sediments, FEMS Microbiol Ecol., 28, 193-202, doi:10.1111/j.1574-6941.1999.tb00575.x, 1999.

Cooper, P.: The absorption of radiation in solar stills, Solar Energy, 12, 333-346, 1969.

Coulson, J. and Butterfield, J.: An investigation of the biotic factors determining the rates of plant decomposition on blanket bog, J. Ecol., 66, 631-650, 1978.

Craine, J. M., Fierer, N., and McLauchlan, K. K.: Widespread coupling between the rate and temperature sensitivity of organic matter decay, Nat. Geosci., 3, 854-857, 2010.

Currey, P. M., Johnson, D., Sheppard, L. J., Leith, I. D., Toberman, H., Van Der WAL, R., Dawson, L. A., and Artz, R. R. E.: Turnover of labile and recalcitrant soil carbon differ in response to nitrate and ammonium deposition in an ombrotrophic Peatland, Glob. Change Biol., 16, 2307-2321, 2010.

Currey, P. M., Johnson, D., Dawson, L. A., van der Wal, R., Thornton, B., Sheppard, L. J., Leith, I. D., and Artz, R. R. E.: Five years of simulated atmospheric nitrogen deposition have only subtle effects on the fate of newly synthesized carbon in Calluna vulgaris and Eriophorum vaginatum, Soil Biol. Biochem., 43, 495-502, doi:10.1016/j.soilbio.2010.11.003, 2011.

Damman, A. W. H.: Regulation of nitrogen removal and retention in Sphagnum bogs and other Peatlands, Oikos, 291-305, 1988.

Davidson, E. A. and Janssens, I. A.: Temperature sensitivity of soil carbon decomposition and feedbacks to climate change, Nature, 440, 165-173, doi:10.1038/nature04514, 2006.

Davie, M. K., Zatsepina, O. Y., and Buffett, B. A.: Methane solubility in marine hydrate environments, Mar. Geol., 203, 177-184, doi:10.1016/s0025-3227(03)00331-1, 2004.

Dimitrov, D. D., Grant, R. F., Lafleur, P. M., and Humphreys, E. R.: Modeling the effects of hydrology on gross primary productivity and net ecosystem productivity at Mer Bleue Bog, J. Geophys. Res., 116, G04010, doi:10.1029/2010jg001586, 2011.

Ellsworth, D. S., Reich, P. B., Naumburg, E. S., Koch, G. W., Kubiske, M. E., and Smith, S. D.: Photosynthesis, carboxylation and leaf nitrogen responses of 16 species to elevated $\mathrm{pCO}_{2}$ across four free-air $\mathrm{CO}_{2}$ enrichment experiments in forest, grassland and desert, Glob. Change Biol., 10, 2121-2138, doi:10.1111/j.1365-2486.2004.00867.x, 2004.

Estop-Aragonés, C., Knorr, K.-H., and Blodau, C.: Controls on in situ oxygen and dissolved inorganic carbon dynamics in Peats of a temperate fen, J. Geophys. Res., 117, G02002, doi:10.1029/2011jg001888, 2012.
Fang, C., Smith, P., Moncrieff, J. B., and Smith, J. U.: Similar response of labile and resistant soil organic matter pools to changes in temperature, Nature, 433, 57-59, 2005.

Field, C. and Mooney, H. A.: The photosynthesis-nitrogen relationship in wild plants, Givnish, 25-56, 1986.

Fraser, C. J. D., Roulet, N. T., and Lafleur, P. M.: Groundwater flow patterns in a large Peatland, J. Hydrol., 246, 142-154, 2001 a.

Fraser, C. J. D., Roulet, N. T., and Moore, T. R.: Hydrology and dissolved organic carbon biogeochemistry in an ombrotrophic bog, Hydrol. Process., 15, 3151-3166, doi:10.1002/hyp.322, 2001b.

Frolking, S., Goulden, M. L., Wofsy, S. C., Fan, S.-M., Sutton, D. J., Munger, J. W., Bazzaz, A. M., Daube, B. C., Crill, P. M., Aber, J. D., Band, L. E., Wang, X., Savage, K., Moore, T., and Harriss, R. C.: Modelling temporal variability in the carbon balance of a spruce/moss boreal forest, Glob. Change Biol., 2, 343-366, 1996.

Frolking, S., Roulet, N. T., Moore, T. R., Richard, P. J., Lavoie, M., and Muller, S. D.: Modeling northern Peatland decomposition and Peat accumulation, Ecosystems, 4, 479-498, 2001.

Frolking, S., Roulet, N. T., Moore, T. R., Lafleur, P. M., Bubier, J. L., and Crill, P. M.: Modeling seasonal to annual carbon balance of Mer Bleue Bog, Ontario, Canada, Global Biogeochem. Cy., 16, 1030, doi:10.1029/2001GB001457, 2002.

Gale, M. and Grigal, D.: Vertical root distributions of northern tree species in relation to successional status, Can. J. Forest Res., 17, 829-834, 1987.

Giardina, C. P. and Ryan, M. G.: Evidence that decomposition rates of organic carbon in mineral soil do not vary with temperature, Nature, 404, 858-861, 2000.

Glass, A. D. M., Brito, D. T., Kaiser, B. N., Kronzucker, H. J., Kumar, A., Okamoto, M., Rawat, S., Siddiqi, M. Y., Silim, S. M., and Vidmar, J. J.: Nitrogen transport in plants, with an emphasis on the regulations of fluxes to match plant demand, J. Plant Nutrition Soil Sci., 164, 199-207, 2001.

Granath, G., Strengbom, J., Breeuwer, A., Heijmans, M. M., Berendse, F., and Rydin, H.: Photosynthetic performance in Sphagnum transplanted along a latitudinal nitrogen deposition gradient, Oecologia, 159, 705-715, doi:10.1007/s00442-0081261-1, 2009.

Granberg, G., Grip, H., Löfvenius, M. O., Sundh, I., Svensson, B., and Nilsson, M.: A simple model for simulation of water content, soil frost, and soil temperatures in boreal mixed mires, Water Resour. Res., 35, 3771-3782, 1999.

Grant, R., Juma, N., and McGill, W.: Simulation of carbon and nitrogen transformations in soil: Mineralization, Soil Biol. Biochem., 25, 1317-1329, 1993.

Güsewell, S.: Responses of wetland graminoids to the relative supply of nitrogen and phosphorus, Plant Ecology, 176, 35-55, 2005.

Heijmans, M. M. P. D., Berendse, F., Arp, W. J., Masselink, A. K., Klees, H., De Visser, W., and Van Breemen, N.: Effects of elevated carbon dioxide and increased nitrogen deposition on bog vegetation in the Netherlands, J. Ecology, 89, 268-279, 2001.

Heijmans, M. M. P. D., Mauquoy, D., Geel, B., and Berendse, F.: Long-term effects of climate change on vegetation and carbon dynamics in Peat bogs, J. Vegetation Sci., 19, 307-320, doi:10.3170/2008-8-18368, 2008.

Heinen, M.: Simplified denitrification models: Overview and properties, Geoderma, 133, 444-463, 
doi:10.1016/j.geoderma.2005.06.010, 2006.

Heitmann, T., Goldhammer, T., Beer, J., and Blodau, C.: Electron transfer of dissolved organic matter and its potential significance for anaerobic respiration in a northern bog, Glob. Change Biol., 13, 1771-1785, doi:10.1111/j.1365-2486.2007.01382.x, 2007.

Hemond, H. F. and Fechner-Levy, E. J.: Chemical fate and transport in the environment, Academic Press, 2000.

Hénault, C. and Germon, J.: NEMIS, a predictive model of denitrification on the field scale, Eur. J. Soil Sci., 51, 257-270, 2008.

Hikosaka, K.: A model of dynamics of leaves and nitrogen in a plant canopy: An integration of canopy photosynthesis, leaf life span, and nitrogen use efficiency, American Naturalist, 162, 149-164, 2003.

Hikosaka, K.: Interspecific difference in the photosynthesisnitrogen relationship: Patterns, physiological causes, and ecological importance, J. Plant Res., 117, 481-494, doi:10.1007/s10265-004-0174-2, 2004.

Granhall, U. and Selander, H.: Nitrogen fixation in a subarctic mire, Oikos, 24, 8-15, 1973.

Inglett, K. S., Inglett, P. W., Reddy, K. R., and Osborne, T. Z.: Temperature sensitivity of greenhouse gas production in wetland soils of different vegetation, Biogeochemistry, 108, 77-90, 2012.

Ingwersen, J., Butterbach-Bahl, K., Gasche, R., Papen, H., and Richter, O.: Barometric process separation: New method for quantifying nitrification, denitrification, and nitrous oxide sources in soils, Soil Sci. Soc. Am. J., 63, 117-128, 1999.

IPCC (Intergovernmental Panel on Climate Change), Climate Change 2007: The Physical Science Basis, in: Contribution of Working Group I to the Fourth Assessment Report of the Intergovernmental Panel on Climate Change, edited by: Solomon, S., Qin, D., Manning, M., Chen, Z., Marquis, M., Averyt, K. B., Tignor, M., and Miller, H. L., Cambridge, United Kingdom and New York, NY, USA, Cambridge University Press, 2007.

Ivanov, K. E.: Water movement in mirelands, Academic Press Inc., London Ltd., 1981.

Jackson, R., Canadell, J., Ehleringer, J., Mooney, H., Sala, O., and Schulze, E.: A global analysis of root distributions for terrestrial biomes, Oecologia, 108, 389-411, 1996.

Janssens, I., Dieleman, W., Luyssaert, S., Subke, J. A., Reichstein, M., Ceulemans, R., Ciais, P., Dolman, A., Grace, J., and Matteucci, G.: Reduction of forest soil respiration in response to nitrogen deposition, Nat. Geosci., 3, 315-322, 2010.

Jauhiainen, J., Vasander, H., and Silvola, J.: Nutrient concentration in shape sphagna at increased $\mathrm{N}$-deposition rates and raised atmospheric $\mathrm{CO}_{2}$ concentrations, Plant Ecology, 138, 149-160, 1998.

Johnsson, H., Bergstrom, L., Jansson, P. E., and Paustian, K.: Simulated nitrogen dynamics and losses in a layered agricultural soil, Agr. Ecosyst. Environ., 18, 333-356, 1987.

Jones, D. L. and Kielland, K.: Soil amino acid turnover dominates the nitrogen flux in permafrost-dominated taiga forest soils, Soil Biol. Biochem., 34, 209-219, 2002.

Jones, D. L., Healey, J. R., Willett, V. B., Farrar, J. F., and Hodge, A.: Dissolved organic nitrogen uptake by plants - an important $n$ uptake pathway?, Soil Biol. Biochem., 37, 413-423, 2005.

Jorgensen, S. E. and Bendoricchio, G.: Fundamentals of Ecological Modelling, 3rd Edn. Elsevier, Amsterdam, 2001.

Juutinen, S., Bubier, J. L., and Moore, T. R.: Responses of vegetation and ecosystem $\mathrm{CO}_{2}$ exchange to 9 years of nu- trient addition at Mer Bleue Bog, Ecosystems, 13, 874-887, doi:10.1007/s10021-010-9361-2, 2010.

Kahmen, A., Livesley, S. J., and Arndt, S. K.: High potential, but low actual, glycine uptake of dominant plant species in three Australian land-use types with intermediate $\mathrm{n}$ availability, Plant Soil, 325, 109-121, 2009.

Karhu, K., Fritze, H., Tuomi, M., Vanhala, P., Spetz, P., Kitunen, V., and Liski, J.: Temperature sensitivity of organic matter decomposition in two boreal forest soil profiles, Soil Biol. Biochem., 42, 72-82, 2010.

Keller, J. K., Weisenhorn, P. B., and Megonigal, J. P.: Humic acids as electron acceptors in wetland decomposition, Soil Biol. Biochem., 41, 1518-1522, 2009.

Keller, J. K., White, J. R., Bridgham, S. D., and Pastor, J.: Climate change effects on carbon and nitrogen mineralization in Peatlands through changes in soil quality, Glob. Change Biol., 10, 1053-1064, 2004.

Khalil, K., Mary, B., and Renault, P.: Nitrous oxide production by nitrification and denitrification in soil aggregates as affected by $\mathrm{O}_{2}$ concentration, Soil Biol. Biochem., 36, 687-699, 2004.

Kielland, K.: Amino acid absorption by arctic plants: Implications for plant nutrition and nitrogen cycling, Ecology, 75, 2373-2383, 1994.

Kielland, K., McFarland, J., and Olson, K.: Amino acid uptake in deciduous and coniferous taiga ecosystems, Plant Soil, 288, 297307, 2006.

Kielland, K., McFarland, J., Ruess, R., and Olson, K.: Rapid cycling of organic nitrogen in taiga forest ecosystems, Ecosystems, 10, 360-368, 2007.

Kimball, J. S., Thornton, P. E., White, M. A., and Running, S. W.: Simulating forest productivity and surface-atmosphere carbon exchange in the BOREAS study region, Tree Physiol., 17, 589599, 1997.

Kirk, G. J. and Kronzucker, H. J.: The potential for nitrification and nitrate uptake in the rhizosphere of wetland plants: A modelling study, Ann. Botany, 96, 639-646, doi:10.1093/aob/mci216, 2005.

Knorr, K.-H. and Blodau, C.: Impact of experimental drought and rewetting on redox transformations and methanogenesis in mesocosms of a northern fen soil, Soil Biol. Biochem., 41, 1187-1198, doi:10.1016/j.soilbio.2009.02.030, 2009.

Kranabetter, J. M., Dawson, C. R., and Dunn, D. E.: Indices of dissolved organic nitrogen, ammonium and nitrate across productivity gradients of boreal forests, Soil Biol. Biochem., 39, 31473158, doi:10.1016/j.soilbio.2007.06.026, 2007.

Kronzucker, H. J., Siddiqi, M. Y., Glass, A. D., and Kirk, G. J.: Nitrate-ammonium synergism in rice. A subcellular flux analysis, Plant Physiol., 119, 1041-1046, 1999.

Lafleur, P. M.: Interannual variability in the Peatland-atmosphere carbon dioxide exchange at an ombrotrophic bog, Global Biogeochem. Cy., 17, 1036, doi:10.1029/2002gb001983, 2003.

Lafleur, P. M., Roulet, N. T., and Admiral, S. W.: Annual cycle of $\mathrm{CO}_{2}$ exchange at a bog Peatland, J. Geophys. Res, 106, 3071, doi:10.1029/2000jd900588, 2001.

Lafleur, P. M., Hember, R. A., Admiral, S. W., and Roulet, N. T.: Annual and seasonal variability in evapotranspiration and water table at a shrub-covered bog in southern Ontario, Canada, Hydrol. Process., 19, 3533-3550, doi:10.1002/hyp.5842, 2005a. 
Lafleur, P. M., Moore, T. R., Roulet, N. T., and Frolking, S.: Ecosystem respiration in a cool temperate bog depends on Peat temperature but not water table, Ecosystems, 8, 619-629, doi:10.1007/s10021-003-0131-2, 2005b.

Lamers, L. P. M., Bobbink, R., and Roelofs, J. G. M.: Natural nitrogen filter fails in polluted raised bogs, Glob. Change Biol., 6, 583-586, 2001.

Lång, K., Lehtonen, M., and Martikainen, P. J.: Nitrification potentials at different $\mathrm{pH}$ values in Peat samples from various layers of a drained mire, Geomicrobiol. J., 11, 141-147, doi:10.1080/01490459309377946, 1993.

Letts, M. G., Roulet, N. T., Comer, N. T., Skarupa, M. R., and Verseghy, D. L.: Parametrization of Peatland hydraulic properties for the canadian land surface scheme, Atmos.-Ocean, 38, $141-160,2000$.

Li, C. and Aber, J.: A process-oriented model of $\mathrm{N}_{2} \mathrm{O}$ and NO, J. Geophys. Res., 105, 4369-4384, 2000.

Limpens, J. and Berendse, F.: Growth reduction of Sphagnum magellanicum subjected to high nitrogen deposition: The role of amino acid nitrogen concentration, Oecologia, 135, 339-345, doi:10.1007/s00442-003-1224-5, 2003.

Limpens, J., Heijmans, M. M. P. D., and Berendse, F.: Nitrogen inpeatlands, in: Boreal peatland ecosystems, edited by: Wieder, R. K. and Vitt, D. H., Ecological Studies Series, Springer Verlag, Berlin, 195-230, 2006.

Linn, D. and Doran, J.: Effect of water-filled pore space on carbon dioxide and nitrous oxide production in tilled and nontilled soils, Soil Sci. Soc. Am. J., 48, 1267-1272, 1984.

Liou, J. S., Derito, C. M., and Madsen, E. L.: Field-based and laboratory stable isotope probing surveys of the identities of both aerobic and anaerobic benzene-metabolizing microorganisms in freshwater sediment, Environ. Microbiol., 10, 19641977, doi:10.1111/j.1462-2920.2008.01612.x, 2008.

Liski, J., Ilvesniemi, H., Mäkelä, A., and Westman, C. J.: CO $\mathrm{CO}_{2}$ emissions from soil in response to climatic warming are overestimated: The decomposition of old soil organic matter is tolerant of temperature, Ambio, 28, 171-174, 1999.

Liu, J., Price, D. T., and Chen, J. M.: Nitrogen controls on ecosystem carbon sequestration: A model implementation and application to Saskatchewan, Canada, Ecol. Model., 186, 178-195, doi:10.1016/j.ecolmodel.2005.01.036, 2005.

Lopes, F., Viollier, E., Thiam, A., Michard, G., Abril, G., Groleau, A., Prévot, F., Carrias, J. F., Albéric, P., and Jézéquel, D.: Biogeochemical modelling of anaerobic vs. aerobic methane oxidation in a meromictic crater lake (Lake Pavin, France), Appl. Geochem., 26, 1919-1932, doi:10.1016/j.apgeochem.2011.06.021, 2011.

Lovley, D. R. and Coates, J. D.: Novel forms of anaerobic respiration of environmental relevance, Curr. Opinion Microbiol., 3, 252-256, 2000.

Lovley, D. R., Coates, J. D., Blunt-Harris, E. L., Phillips, E. J. P., and Woodward, J. C.: Humic substances as electron acceptors for microbial respiration, Nature, 382, 445-448, 1996.

Lund, M., Lafleur, P. M., Roulet, N. T., Lindroth, A., Christensen, T. R., Aurela, M., Chojnicki, B. H., Flanagan, L. B., Humphreys, E. R., Laurila, T., Oechel, W. C., Olejnik, J., Rinne, J., Schubert, P. E. R., and Nilsson, M. B.: Variability in exchange of $\mathrm{CO}_{2}$ across 12 northern Peatland and tundra sites, Glob. Change Biol., 16, 2436-2448, doi:10.1111/j.1365-2486.2009.02104.x, 2009.
Malmer, N., Johansson, T., Olsrud, M., and Christensen, T. R.: Vegetation, climatic changes and net carbon sequestration in a northscandinavian subarctic mire over 30 years, Glob. Change Biol., 11, 1895-1909, 2005.

Manzoni, S., Trofymow, J. A., Jackson, R. B., and Porporato, A.: Stoichiometric controls on carbon, nitrogen, and phosphorus dynamics in decomposing litter, Ecol. Monogr., 80, 89-106, 2010.

Miller, A. J. and Cramer, M. D.,: Root nitrogen acquisition and assimilation, Plant Soil, 274, 1-36, doi:10.1007/s11104-004-0965$1,2004$.

Moore, T., Roulet, N., and Waddington, J.: Uncertainty in predicting the effect of climatic change on the carbon cycling of Canadian Peatlands, Climatic Change, 40, 229-245, 1998.

Moore, T. R., Bubier, J. L., Frolking, S. E., Lafleur, P. M., and Roulet, N. T.: Plant biomass and production and $\mathrm{CO}_{2}$ exchange in an ombrotrophic bog, J. Ecology, 90, 25-36, 2002.

Moore, T. R., Blodau, C., Turunen, J., Roulet, N., and Richard, P. J. H.: Patterns of nitrogen and sulfur accumulation and retention in ombrotrophic bogs, eastern Canada, Glob. Change Biol., 11, 356-367, doi:10.1111/j.1365-2486.2004.00882.x, 2005.

Moore, T. R., Lafleur, P. M., Poon, D. M. I., Heumann, B. W., Seaquist, J. W., and Roulet, N. T.: Spring photosynthesis in a cool temperate bog, Glob. Change Biol., 12, 2323-2335, doi:10.1111/j.1365-2486.2006.01247.x, 2006.

Moore, T. R., Young, A., Bubier, J. L., Humphreys, E. R., Lafleur, P. M., and Roulet, N. T.: A multi-year record of methane flux at the Mer Bleue Bog, southern Canada, Ecosystems, 14, 646-657, doi:10.1007/s10021-011-9435-9, 2011.

Morris, P. J., Waddington, J. M., Benscoter, B. W., and Turetsky, M. R.: Conceptual frameworks in Peatland ecohydrology: Looking beyond the two-layered (acrotelm-catotelm) model, Ecohydrology, 4, 1-11, doi:10.1002/eco.191, 2011.

Murphy, M. T. and Moore, T. R.: Linking root production to aboveground plant characteristics and water table in a temperate bog, Plant Soil, 336, 219-231, doi:10.1007/s11104-010-0468-1, 2010.

Murphy, M. T., McKinley, A., and Moore, T. R.: Variations in above- and below-ground vascular plant biomass and water table on a temperate ombrotrophic Peatland, Botany, 87, 845-853, doi:10.1139/b09-052, 2009.

Murray, R. E. and Knowles. R.: Production of $\mathrm{NO}$ and $\mathrm{N}_{2} \mathrm{O}$ in the presence and absence of $\mathrm{C}_{2} \mathrm{H}_{2}$ by soil slurries and batch cultures of denitrifying bacteria, Soil Biol. Biochem., 35, 1115$1122,2003$.

Nasholm, T., Kielland, K., and Ganeteg, U.: Uptake of organic nitrogen by plants, The New Phytologist, 182, 31-48, doi:10.1111/j.1469-8137.2008.02751.x, 2009.

Nedwell, D. B., and Watson, A,: $\mathrm{CH}_{4}$ production, oxidation and emission in a UK ombrotrophic Peat bog: Influence of $\mathrm{SO}_{4}^{2-}$ from acid rain, Soil Biol. Biochem., 27, 893-903, 1995.

Neff, J. C., Townsend, A. R., Gleixner, G., Lehman, S. J., Turnbull, J., and Bowman, W. D.: Variable effects of nitrogen additions on the stability and turnover of soil carbon, Nature, 419, 915-917, doi:10.1038/nature01136, 2002.

Nielsen, L. P., Risgaard-Petersen, N., Fossing, H., Christensen, P. B., and Sayama, M.: Electric currents couple spatially separated biogeochemical processes in marine sediment, Nature, 463, 1071-1074, doi:10.1038/nature08790, 2010. 
Norby, R. J., Cortufo, M. F., Ineson, P., Neill, E. G. O., and Canadell, J. G.: Elevated $\mathrm{CO}_{2}$, litter chemistry, and decomposition: A synthesis, Oecologia, 127, 153-165, doi:10.1007/s004420000615, 2001.

Nordin, A., Strengbom, J., Witzell, J., Näsholm, T., and Ericson, L.: Nitrogen deposition and the biodiversity of boreal forests: Implications for the nitrogen critical load, AMBIO, 34, 20-24, 2005.

Novák, M. and Wieder, R. K.: Inorganic and organic sulfur profiles in nine Sphagnum Peat bogs in the United States and Czechoslovakia, Water Air Soil Pollut., 65, 353-369, 1992.

Parsons, D. A. B., Scholes, M. C., Scholes, R. J., and Levine, J. S.: Biogenic NO emissions from savanna soils as a function of fire regime, soil type, soil nitrogen, and water status, J. Geophys. Res., 101, 23683-23688, doi:10.1029/95JD02140, 1996.

Parton, W., Scurlock, J., Ojima, D., Gilmanov, T., Scholes, R., Schimel, D., Kirchner, T., Menaut, J., Seastedt, T., and Moya, E. G.: Observations and modeling of biomass and soil organic matter dynamics for the grassland biome worldwide, Global Biogeochem. Cy., 7, 785-809, 1993.

Pastor, J., Peckham, B., Bridgham, S., Weltzin, J., and Chen, J.: Plant community dynamics, nutrient cycling, and alternative stable equilibria in Peatlands, American Naturalist, 160, 553-568, 2002.

Potter, C. S.: An ecosystem simulation model for methane production and emission from wetlands, Global Biogeochem. Cy., 11, 495-506, 1997.

Reddy, K. R., Patrick, W. H., and Broadbent, F. E.: Nitrogen transformations and loss in flooded soils and sediments, Critical Rev. Environ. Sci. Technol., 13(4), 273-309, 1984.

Reguera, G., McCarthy, K. D., Mehta, T., Nicoll, J. S., Tuominen, M. T., and Lovley, D. R.: Extracellular electron transfer via microbial nanowires, Nature, 435, 1098-1101, doi:10.1038/nature03661, 2005.

Reich, P., Walters, M., Kloeppel, B., and Ellsworth, D.: Different photosynthesis-nitrogen relations in deciduous hardwood and evergreen coniferous tree species, Oecologia, 104, 24-30, 1995.

Reimer, A.: The role of bog plants in the exchange of carbon and water between the atmosphere and the Mer Bleue Peatland, MSc thesis, McGill University, Montreal., 2001.

Reynolds, J. F. and Thornley, J. H. M.: A shoot: root partitioning model, Ann. Botany, 49, 585-597, 1982.

Riedo, M., Grub, A., Rosset, M., and Fuhrer, J.: A pasture simulation model for dry matter production, and fluxes of carbon, nitrogen, water and energy, Ecol. Model., 105, 141-183, 1998.

Robroek, B. J. M., Schouten, M. G. C., Limpens, J., Berendse, F., and Poorter, H.: Interactive effects of water table and precipitation on net $\mathrm{CO}_{2}$ assimilation of three co-occurring Sphagnum mosses differing in distribution above the water table, Glob. Change Biol., 15, 680-691, doi:10.1111/j.13652486.2008.01724.x, 2009.

Roden, E. E., Kappler, A., Bauer, I., Jiang, J., Paul, A., Stoesser, R., Konishi, H., and $\mathrm{Xu}, \mathrm{H} .:$ Extracellular electron transfer through microbial reduction of solid-phase humic substances, Nat. Geosci., 3, 417-421, 2010.

Rosswall, T. and Granhall, U.: Nitrogen cycling in a subarctic ombrotrophic mire, Ecol. Bullet., 209-234, 1980.

Roulet, N. T., Lafleur, P. M., Richard, P. J. H., Moore, T. R., Humphreys, E. R., and Bubier, J.: Contemporary carbon balance and late Holocene carbon accumulation in a northern
Peatland, Glob. Change Biol., 13, 397-411, doi:10.1111/j.13652486.2006.01292.x, 2007.

Ryan, M. G.: Effects of climate change on plant respiration, Ecol. Appl., 1, 157-167, 1991.

Ryan, M. G.: Foliar maintenance respiration of subalpine and boreal trees and shrubs in relation to nitrogen content, Plant Cell Environ., 18, 765-772, 1995.

Sage, R. F. and Pearcy, R. W.: The nitrogen use efficiency of C3 and C4 plants ii. Leaf nitrogen effects on the gas exchange characteristics of Chenopodium Album (L.) and Amaranthus Retroflexus (L.), Plant Physiol., 84, 959-963, 1987.

Sauheitl, L., Glaser, B., and Weigelt, A.: Uptake of intact amino acids by plants depends on soil amino acid concentrations, Environ. Experiment. Bot., 66, 145-152, 2009.

Scott, D. T., McKnight, D. M., Blunt-Harris, E. L., Kolesar, S. E., and Lovley, D. R.: Quinone moieties act as electron acceptors in the reduction of humic substances by humics-reducing microorganisms, Environ. Sci. Technol., 32, 2984-2989, 1998.

Segers, R. and Kengen, S.: Methane production as a function of anaerobic carbon mineralization: A process model, Soil Biol. Biochem., 30, 1107-1117, 1998.

Segers, R. and Leffelaar, P. A.: Modeling methane fluxes in wetlands with gas-transporting plants: 1 . Single-root scale, J. Geophys. Res., 106, 3511, doi:10.1029/2000jd900484, 2001.

Small, E.: Photosynthetic rates in relation to nitrogen recycling as an adaptation to nutrient deficiency in Peat bog plants, Can. J. Botany, 50, 2227-2233, 1972.

Smart, D. R. and Bloom, A. J.,: Influence of root and content on the temperature response of net and uptake in chilling sensitive and chilling resistant Lycopersicon taxa, J. Experiment. Botany, 42, 331-338, 1991.

Smemo, K. A. and Yavitt, J. B.: Anaerobic oxidation of methane: an underappreciated aspect of methane cycling in peatland ecosystems?, Biogeosciences, 8, 779-793, doi:10.5194/bg-8-779-2011, 2011.

St-Hilaire, F., Wu, J., Roulet, N. T., Frolking, S., Lafleur, P. M., Humphreys, E. R., and Arora, V.: McGill wetland model: evaluation of a peatland carbon simulator developed for global assessments, Biogeosciences, 7, 3517-3530, doi:10.5194/bg-7-35172010, 2010.

Thornley, J.: Dynamic model of leaf photosynthesis with acclimation to light and nitrogen, Ann. Botany, 81, 421-430, 1998a.

Thornley, J. H. M.: Grassland dynamics: An ecosystem simulation model, CAB International Wallingford UK, 241 pp., ISBN 0 85199-227-7, 1998b.

Thornley, J. H. M.: Instantaneous canopy photosynthesis: Analytical expressions for sun and shade leaves based on exponential light decay down the canopy and an acclimated non-hyperbola for leaf photosynthesis, Ann. Botany, 89, 451-458, 2002.

Thornley, J. and Cannell, M.: Nitrogen relations in a forest plantation - soil organic matter ecosystem model, Ann. Botany, 70, 137-151, 1992.

Thornley, J. and Cannell, M.: Soil carbon storage response to temperature: An hypothesis, Ann. Botany, 87, 591-598, 2001.

Thornley, J. and Verberne, E.: A model of nitrogen flows in grassland, Plant Cell Environ., 12, 863-886, 1989.

Thornley, J., Bergelson, J., and Parsons, A.: Complex dynamics in a carbon-nitrogen model of a grass-legume pasture, Ann. Botany, 75, 79-84, 1995. 
Trettin, C. C., Song, B., Jurgensen, M., and Li, C.: Existing soil carbon models do not apply to forested wetlands, USDA Forest Service, Savannah River, New Ellenton, SC, 2001.

Trumbore, S. E., and Harden, J.: Accumulation and turnover of carbon in organic and mineral soils of the boreas northern study area, J. Geophys. Res., 102 28817-28830, 1997.

Turunen, J., Tomppo, E., Tolonen, K., and Reinikainen, A.: Estimating carbon accumulation rates of undrained mires in finlandapplication to boreal and subarctic regions, The Holocene, 12, 69-80, 2002.

Updegraff, K., Pastor, J., Bridgham, S. D., and Johnston, C. A.: Environmental and substrate controls over carbon and nitrogen mineralization in northern wetlands, Ecol. Appl., 5, 151-163, 1995.

Urban, N., Eisenreich, S., and Bayley, S.: The relative importance of denitrification and nitrate assimilation in midcontinental bogs, Limnol. Oceanogr., 33, 1611-1617, doi:10.4319/lo.1988.33.6_part_2.1611, 1988.

Valenzuela-Estrada, L. R., Vera-Caraballo, V., Ruth, L. E., and Eissenstat, D. M.: Root anatomy, morphology, and longevity among root orders in Vaccinium Corymbosum (Ericaceae), Am. J. Botany, 95, 1506-1514, doi:10.3732/ajb.0800092, 2008.

van Bellen, S., Dallaire, P. L., Garneau, M., and Bergeron, Y.: Quantifying spatial and temporal Holocene carbon accumulation in ombrotrophic Peatlands of the eastmain region, Quebec, Canada, Global Biogeochem. Cy., 25, GB2016, doi:10.1029/2010gb003877, 2011a.

van Bellen, S., Garneau, M., and Booth, R. K.: Holocene carbon accumulation rates from three ombrotrophic Peatlands in boreal Quebec, Canada: Impact of climate-driven ecohydrological change, The Holocene, 21, 1217-1231, 2011b.

Van Der Heijden, E., Verbeek, S. K., and Kuiper, P. J. C.: Elevated atmospheric $\mathrm{CO}_{2}$ and increased nitrogen deposition: Effects on $\mathrm{C}$ and $\mathrm{N}$ metabolism and growth of the Peat moss Sphagnum recurvum P. Beauv. Var. mucronatum (Russ.) Warnst, Glob. Change Biol., 6, 201-212, 2001.

Van der Peijl, M. and Verhoeven, J.: A model of carbon, nitrogen and phosphorus dynamics and their interactions in river marginal wetlands, Ecol. Model., 118, 95-130, 1999.

Van Oene, H., Van Deursen, E. J. M., and Berendse, F.: Plantherbivore interaction and its consequences for succession in wetland ecosystems: A modeling approach, Ecosystems, 2, 122138, 1999.

Vile, M. A.: Atmospheric sulfur deposition alters pathways of gaseous carbon production in Peatlands, Global Biogeochem. Cy., 17, doi:10.1029/2002gb001966, 2003a.

Vile, M. A., Bridgham, S. D., and Wieder, R. K.: Response of anaerobic carbon mineralization rates to sulfate amendments in a boreal Peatland, Ecol. Appl., 13, 720-734, 2003b.

Vitt, D. H., Halsey, L. A., Bauer, I. E., and Campbell, C.: Spatial and temporal trends in carbon storage of Peatlands of continental western canada through the Holocene, Can. J. Earth Sci., 37, 683-693, 2000.

Vitt, D. H., Wieder, K., Halsey, L. A., and Turetsky, M.: Response of Sphagnum fuscum to nitrogen deposition: A case study of ombrogenous Peatlands in Alberta, Canada, The Bryologist, 106, 235-245, 2003.

Walter, B., Heimann, M., and Matthews, E.: Modeling modern methane emissions from natural wetlands, I- model description and results, J. Geophys. Res. Atmos., 106, 34189-34206,
doi:10.1029/2001JD900165, 2001.

Well, R., Augustin, J., Meyer, K., and Myrold, D. D.: Comparison of field and laboratory measurement of denitrification and $\mathrm{N}_{2} \mathrm{O}$ production in the saturated zone of hydromorphic soils, Soil Biol. Biochem., 35, 783-799, 2003.

Weltzin, J. F., Bridgham, S. D., Pastor, J., Chen, J., and Harth, C.: Potential effects of warming and drying on Peatland plant community composition, Glob. Change Biol., 9, 141-151, 2003.

Wendel, S., Moore, T., Bubier, J., and Blodau, C.: Experimental nitrogen, phosphorus, and potassium deposition decreases summer soil temperatures, water contents, and soil $\mathrm{CO}_{2}$ concentrations in a northern bog, Biogeosciences, 8, 585-595, doi:10.5194/bg8-585-2011, 2011.

Wieder, R. K. and Vitt, D. H.: Boreal Peatland ecosystems, Springer, 2006.

Williams, B. and Silcock, D.: Nutrient and microbial changes in the Peat profile beneath Sphagnum magellanicum in response to additions of ammonium nitrate, J. Appl. Ecol., 34, 961-970, 1997.

Williams, L. and Miller, A.: transporters responsible for the uptake and partitioning of nitrogenous solutes, Ann. Rev. Plant Biol., 52, 659-688, 2001.

Williams, T. G. and Flanagan, L. B.: Measuring and modelling environmental influences on photosynthetic gas exchange in Sphagnum and Pleurozium, Plant Cell Environ., 21, 555-564, doi:10.1046/j.1365-3040.1998.00292.x, 1998.

Willmott, C. J.: SOMe comments on the evaluation of model performance, B. Am. Meteorol. Soc., 63, 1309-1369, 1982.

Wu, J., Roulet, N. T., Moore, T. R., Lafleur, P., and Humphreys, E.: Dealing with microtopography of an ombrotrophic bog for simulating ecosystem-level $\mathrm{CO}_{2}$ exchanges, Ecol. Model., 222, 1038-1047, 2011.

Xing, Y., Bubier, J., Moore, T., Murphy, M., Basiliko, N., Wendel, S., and Blodau, C.: The fate of ${ }^{15} \mathrm{~N}$-nitrate in a northern Peatland impacted by long term experimental nitrogen, phosphorus and potassium fertilization, Biogeochemistry, 103, 281-296, doi:10.1007/s10533-010-9463-0, 2010.

$\mathrm{Xu}, \mathrm{R}$. and Prentice, I. C.: Terrestrial nitrogen cycle simulation with a dynamic global vegetation model, Glob. Change Biol., 14, 1745-1764, 2008.

Yasumura, Y., Hikosaka, K., and Hirose, T.: Seasonal changes in photosynthesis, nitrogen content and nitrogen partitioning in Lindera umbellata leaves grown in high or low irradiance, Tree Physiology, 26, 1315-1323, 2006.

Yu, Z., Loisel, J., Brosseau, D. P., Beilman, D. W., and Hunt, S. J.: Global Peatland dynamics since the last glacial maximum, Geophys. Res. Lett., 37, L13402, doi:10.1029/2010g1043584, 2010.

Zhang, Y.: An integrated model of soil, hydrology, and vegetation for carbon dynamics in wetland ecosystems, Global Biogeochem. Cy., 16, 1061, doi:10.1029/2001gb001838, 2002.

Zhang, Y., Grant, R. F., Flanagan, L. B., Wang, S., and Verseghy, D. L.: Modelling $\mathrm{CO}_{2}$ and energy exchanges in a northern semiarid grassland using the carbon- and nitrogen-coupled canadian land surface scheme (C-CLASS), Ecol. Model., 181, 591-614, doi:10.1016/j.ecolmodel.2004.07.007, 2005.

Zhuang, Q.: Methane fluxes between terrestrial ecosystems and the atmosphere at northern high latitudes during the past century: A retrospective analysis with a process-based biogeochemistry model, Global Biogeochem. Cy., 18, GB3010, doi:10.1029/2004gb002239, 2004. 